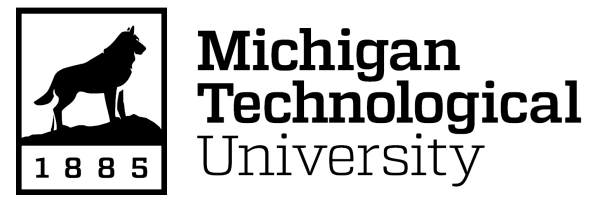

Michigan Technological University Digital Commons @ Michigan Tech

Dissertations, Master's Theses and Master's Reports

2019

\title{
A Preliminary Sustainability Analysis of Producing Class A Biosolids with Conventional and Low-Cost, Low-Tech Processes
}

Janna Brown

Michigan Technological University, jannab@mtu.edu

Copyright 2019 Janna Brown

\section{Recommended Citation}

Brown, Janna, "A Preliminary Sustainability Analysis of Producing Class A Biosolids with Conventional and Low-Cost, Low-Tech Processes", Open Access Master's Report, Michigan Technological University, 2019. https://doi.org/10.37099/mtu.dc.etdr/851

Follow this and additional works at: https://digitalcommons.mtu.edu/etdr

Part of the Environmental Engineering Commons 
A PRELIMINARY SUSTAINABILITY ANALYSIS OF PRODUCING CLASS A BIOSOLIDS WITH CONVENTIONAL AND LOW-COST, LOW-TECH PROCESSES

By

Janna L. Brown

\begin{abstract}
A REPORT
Submitted in partial fulfillment of the requirements for the degree of MASTER OF SCIENCE

In Environmental Engineering
\end{abstract}

MICHIGAN TECHNOLOGICAL UNIVERSITY

2019

(C) 2019 Janna L. Brown 
This report has been approved in partial fulfillment of the requirements for the Degree of MASTER OF SCIENCE in Environmental Engineering.

Department of Civil and Environmental Engineering

\author{
Report Co-Advisor: Dr. Jennifer Becker \\ Report Co-Advisor: $\quad$ Dr. Eric Seagren \\ Committee Member: Dr. Robert Handler \\ Department Chair: Dr. Audra Morse
}




\section{Table of Contents}

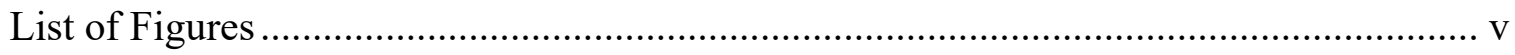

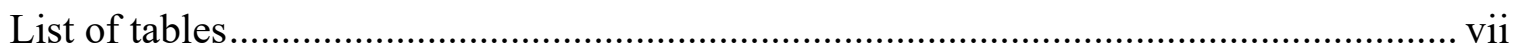

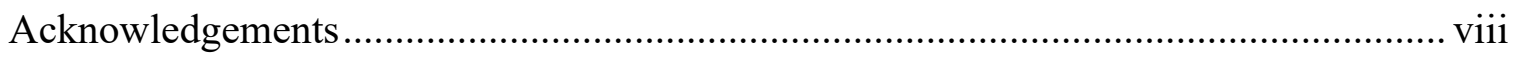

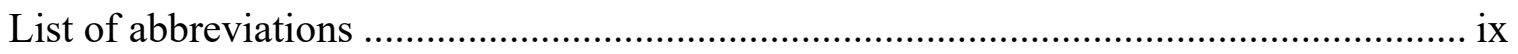

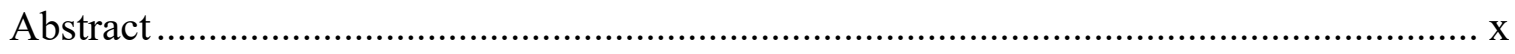

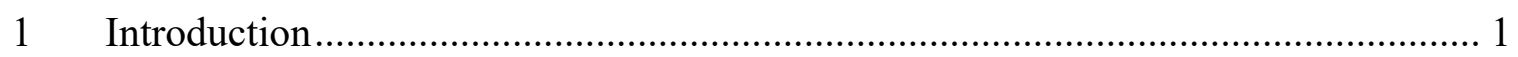

1.1 Biosolids Use, Regulations, and Treatment Technologies .............................. 1

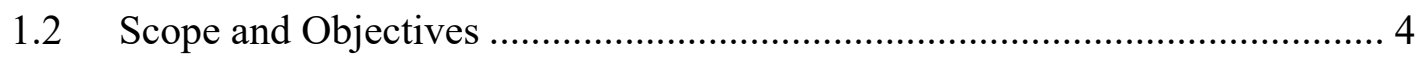

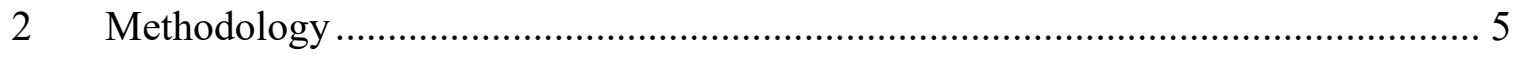

2.1 Environmental Impacts........................................................................ 5

2.1.1 Goal, Scope, and Functional Unit ................................................ 5

2.1.2 SimaPro Methods ............................................................................... 6

2.1.3 Input and output data for each biosolids production process.............. 7

2.1.3.1 Air Drying ................................................................... 9

2.1.3.2 Lagoon Storage plus Air Drying.................................... 11

2.1.3.3 Composting .................................................................. 14

2.1.3.4 Direct Heat Drying......................................................... 15

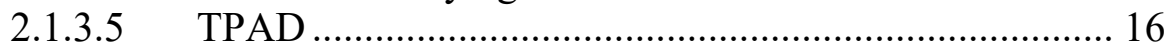

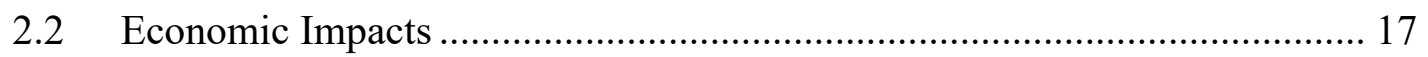

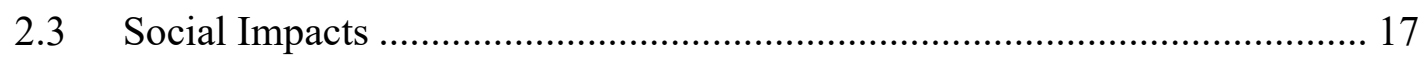

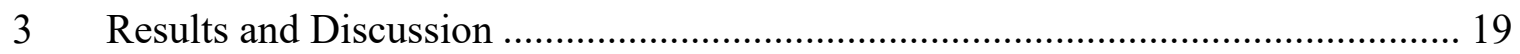

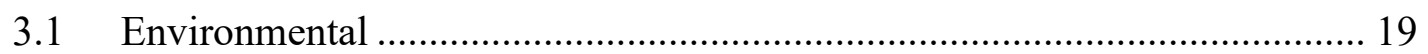

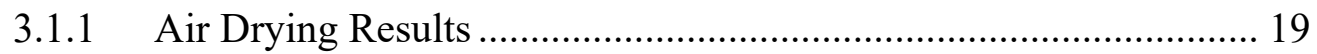

3.1.1.1 Sensitivity Analysis ...................................................... 21

3.1.2 Lagoon Storage plus Air Drying Results ………….......................... 22

3.1.2.1 Air Drying Unit Sensitivity Analysis............................. 24

3.1.3 Composting Results ................................................................... 24

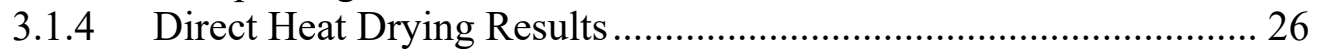

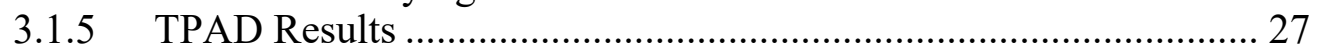

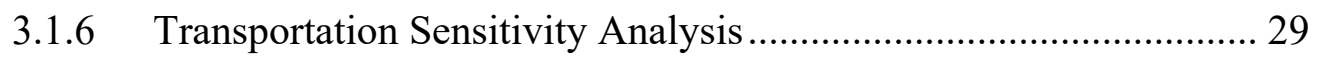

3.1.7 Greenhouse Gas Emissions Comparison ………………………..... 30

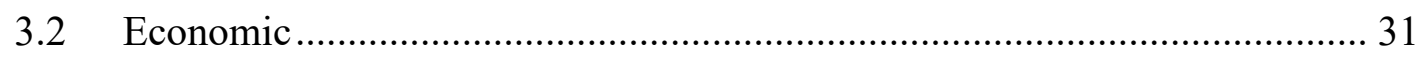

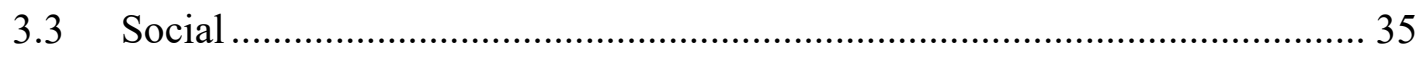

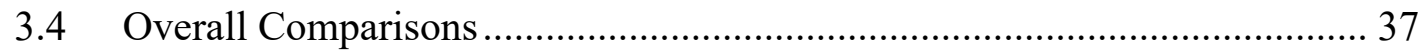


4 Conclusion

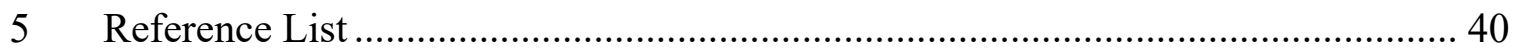

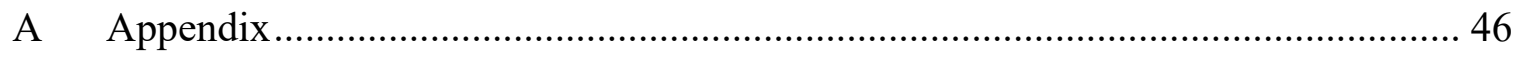

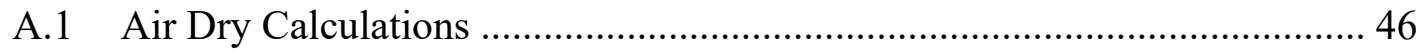

A.1.1 Air Drying Detailed Results.................................................... 56

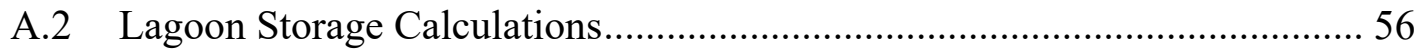

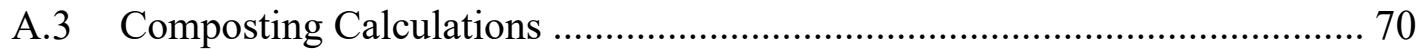

A.3.1 Composting Detailed Results................................................... 79

A.4 Direct Heat Drying Calculations ........................................................... 80

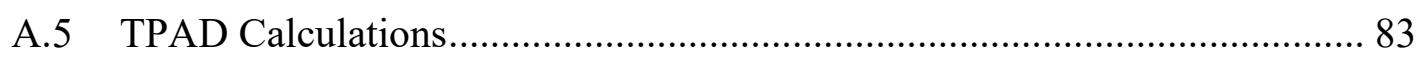

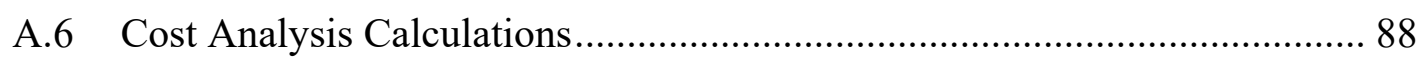

A.6.1 Air Drying cost calculations ................................................... 88

A.6.2 Lagoon Storage cost calculations.............................................. 89

A.6.3 Composting Cost Calculations................................................... 92

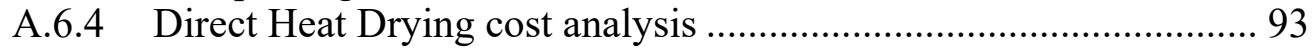

A.6.5 TPAD cost analysis ........................................................... 94 


\section{List of Figures}

Figure 2.1. System boundaries for each treatment process .......................... 6

Figure 2.2. Mass flow through the process trains $\ldots \ldots \ldots \ldots \ldots \ldots \ldots \ldots \ldots \ldots \ldots \ldots \ldots \ldots$

Figure 2.3. Lagoon management scheme with storage time required ................. 13

Figure 3.1. Overall environmental impacts for each processing using IMPACT 2002+

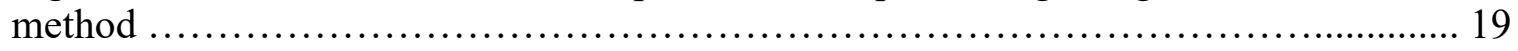

Figure 3.2. Environmental impacts of air drying unit processes ..................... 20

Figure 3.3. Environmental impacts of air drying separated by utilities/fuel, materials, biogenic, and infrastructure sources .............................................. 21

Figure 3.4. Air drying sensitivity analysis results ............................... 22

Figure 3.5. Environmental impacts of lagoon storage unit processes ................... 23

Figure 3.6. Environmental impacts of lagoon storage separated by utilities/fuel, materials, biogenic, and infrastructure sources ............................................. 23

Figure 3.7. Lagoon storage sensitivity analysis results ............................ 24

Figure 3.8. Environmental impacts of composting unit processes .................... 25

Figure 3.9. Environmental impacts of composting separated by utilities/fuel, materials, biogenic, and infrastructure sources ............................................ 25

Figure 3.10. Environmental impacts of direct heat drying unit processes ............... 26

Figure 3.11. Environmental impacts of direct heat drying separated by utilities/fuel, materials, biogenic, and infrastructure sources ................................... 27

Figure 3.12. Environmental impacts of TPAD unit processes ........................ 28

Figure 3.13. Environmental impacts of TPAD separated by utilities/fuel, materials, biogenic, and infrastructure sources ............................................ 28

Figure 3.14. Transportation sensitivity analysis .................................. 30

Figure 3.15. Biogenic emissions for air drying, lagoon storage, and composting ......... 31

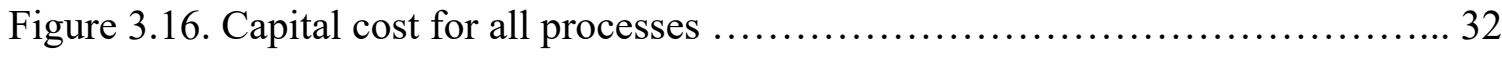

Figure 3.17. First year of operations and maintenance (O\&M) cost for all processes ... 33 
Figure 3.18. O\&M costs broken down to the individual components ................. 34

Figure 3.19. Life time cost for each process components ........................ 35

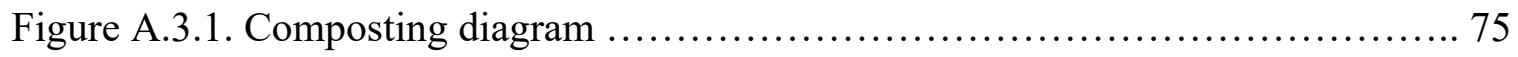




\section{List of tables}

Table 1.1. Class A and class B pathogen limits and vector attraction reduction .......... 2

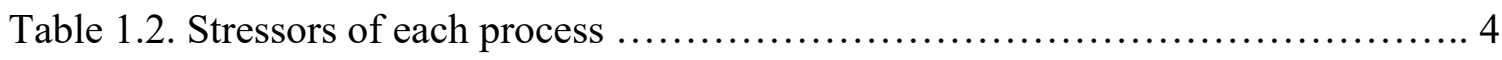

Table 2.1. IMPACT 2002+ indicators and damage categories ...................... 7

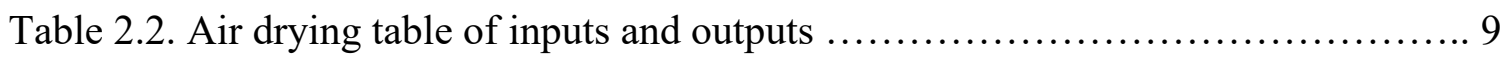

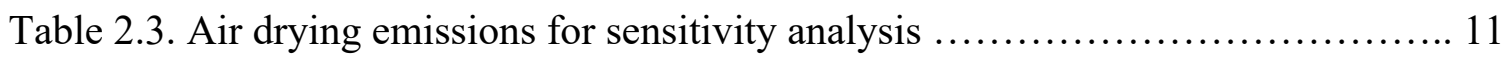

Table 2.4. Lagoon storage table of inputs and outputs......................... 12

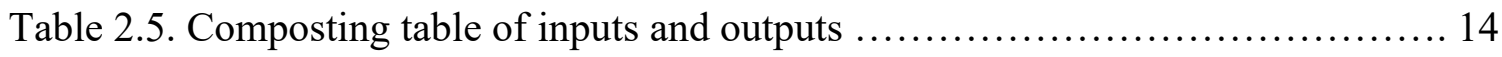

Table 2.6. Direct heat drying table of inputs and outputs.......................... 16

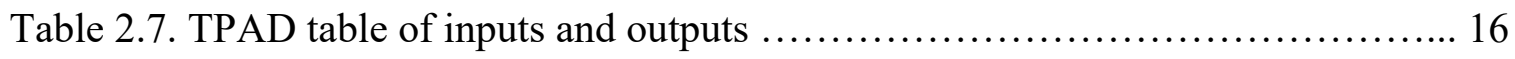

Table 3.1. Different ways to rank the economic impacts ........................ 35

Table 3.2. Treatment processes scored with public's concerns $\ldots \ldots \ldots \ldots \ldots \ldots \ldots \ldots \ldots \ldots \ldots$

Table 3.3. Environmental economic, and social impacts ranked by ranking scheme \#1

Table 3.4. Environmental economic, and social impacts ranked by ranking scheme \#2 .......................................................................... 38

Table A.1.1 Air drying unit process breakdown by inputs and outputs................. 56

Table A.3.1. Quantity of biosolids and amendments in composting cycles ........... 75

Table A.3.2. Composting unit process environmental impacts broken down by inputs and

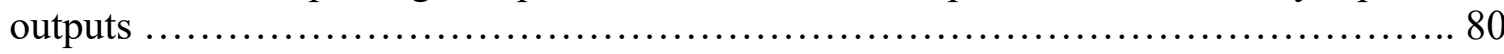

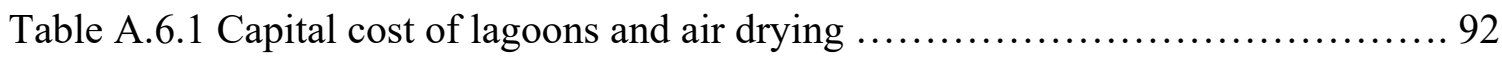




\section{Acknowledgements}

I would like to express my appreciation to Dr. Becker, Dr. Handler, and Dr. Seagren for their valuable help and guidance during my research.

Funding provided by Great Lakes Environmental Infrastructure Center (GLEIC). 


\title{
List of abbreviations
}

\author{
WRRF $=$ Water Resources Recovery Facility \\ LCLT $=$ Low-Cost, Low-Tech \\ $\mathrm{AD}=$ Air Drying \\ HDPE $=$ high density polyethylene \\ $\mathrm{C} / \mathrm{N}=$ carbon nitrogen ratio \\ GWP $=$ Global Warming Potential \\ $\mathrm{TS}=$ Total Solids \\ VS $=$ Volatile Solids \\ MPN $=$ Most Probable Number \\ $\mathrm{CFU}=$ Colony-Forming Unit \\ VSS $=$ Volatile Suspended Solids \\ IPCC $=$ Intergovernmental Panel on Climate Change \\ SRT $=$ Solids Retention Time
}




\section{Abstract}

Producing Class A biosolids is a beneficial way to reuse wastewater sludge. Low-cost, low-tech (LCLT) processes are attractive to small water resource recovery facilities (WRRF) because of their low capital costs and simple designs. This study examined the sustainability of conventional and LCLT processes at small WRRFs. The environmental impacts were determined by conducting life cycle assessments. Cost analyses determined the economic impacts. The social impacts were analyzed by investigating case studies and surveys of social response to biosolids. The environmental, economic, and social impacts were normalized, and each technology received an overall score. The technologies studied were direct heat drying, composting, lagoon storage, air drying, and TPAD. Preliminary results indicated that composting, direct heat drying, and lagoon storage had the most significant environmental impacts. The majority of impacts are from biogenic emissions. Composting and direct heat drying scored the worst overall while air drying and TPAD scored the best. 


\section{Introduction}

\subsection{Biosolids Use, Regulations, and Treatment Technologies}

Water resources recovery facilities (WRRFs) produce treated organic solids known as biosolids (Walker, Knight et al. 1994). Biosolids have characteristics that make them for valuable beneficial reuse via land application. For example, biosolids are a good source of organic matter and, depending on the treatment technology, they can be rich in nutrients like nitrogen, phosphate, and potassium (Vasileski 2007). Biosolids can also improve the soil's structure, and provide the soil with additional iron (Vasileski 2007).

Consistent with these benefits, a survey conducted in 2004 found that $55 \%$ of wastewater solids produced in the United States (USEPA) are treated and beneficially reused as land applied biosolids, primarily (75\%) on agriculture lands (NEBRA 2011). According to the survey, of the remaining biosolids that are not land applied, 30\% are landfilled and $15 \%$ are incinerated. Thus, land application of biosolids has the added benefit of conserving landfill space (Vasileski 2007). Small WRRFs are more likely to landfill biosolids, because they deem it too difficult to set up a beneficial use program (NEBRA 2011).

Although there are many benefits to land application, the biosolids potentially contain pathogens. Therefore, the biosolids must be treated to reduce pathogen and indicator organism (PIO) level and stabilize the organic matter in the biosolids, thereby reducing their tendency to attract vectors (e.g. rats, etc.) before being land-applied. Accordingly, Part 503 of Tile 40 of the Code of Federal Regulations (CFR) regulates the application of biosolids to be protective of human health and biosolids as either Class A or Class B depending on the levels of PIO they are permitted to contain (Walker, Knight et al. 1994), as summarized in Table 1.1. Because of less stringent PIO standards, Class B biosolids have stricter regulations to follow if applied to land. Specifically, there are restrictions on the amount of time that needs to pass before crops and turf can grow, animals can graze, and the public may have contact (Walker, Knight et al. 1994). In comparison, Class A biosolids have a larger applicability due to their lower pathogen limits. 
Table 1.1 Class A and class B pathogen limits and vector attraction reduction where $\mathrm{MPN}=$ Most probable number, $\mathrm{CFU}=$ Colony-Forming Unit, and TS $=$ Total solids .

\begin{tabular}{|c|c|c|}
\hline & Class A & Class B \\
\hline Pathogen Limits & $\begin{array}{l}\text { Enteric virus limits }=<1 \\
\mathrm{PFU} / 4 \mathrm{~g} \mathrm{TS}^{\mathrm{b}} \\
\text { Helminth limits }=<1 \text { viable } \\
{\text { ovum } / 4 \mathrm{~g} \mathrm{TS}^{\mathrm{b}}} \\
\text { Fecal coliform limits }= \\
<1,000 \mathrm{MPN} / 4 \mathrm{~g} \mathrm{TS}{ }^{\mathrm{a}} \\
\text { OR } \\
\text { Salmonellae limits }=<3 \\
\text { MPN/g TS }^{\mathrm{a}}\end{array}$ & $\begin{array}{l}<2 \text { million MPN fecal coliform/g } \\
\mathrm{TS} \text { OR }<2 \text { million } \mathrm{CFU} / \mathrm{g} \mathrm{TS}^{\mathrm{a}}\end{array}$ \\
\hline $\begin{array}{l}\text { Pathogen Reduction } \\
\text { Alternatives }\end{array}$ & $\begin{array}{l}\text { Meet } 1 \text { of } 6 \text { alternatives in } \\
40 \text { CFR } 503^{\mathrm{a}}\end{array}$ & $\begin{array}{l}\text { Meet } 1 \text { of } 3 \text { alternatives in } 40 \\
\text { CFR } 503^{\text {a }}\end{array}$ \\
\hline $\begin{array}{l}\text { Vector Attraction } \\
\text { Requirements }\end{array}$ & $\begin{array}{l}\text { Meet } 1 \text { vector attraction } \\
\text { reduction options in } 40 \text { CFR } \\
503^{\text {a }}\end{array}$ & $\begin{array}{l}\text { Meet } 1 \text { vector attraction } \\
\text { reduction options in } 40 \text { CFR } \\
503^{\text {a }}\end{array}$ \\
\hline
\end{tabular}

a(Walker, Knight et al. 1994)

b(Farrell, Merrill et al. 2004)

Despite the real value of biosolids as a soil amendment and source of plant nutrient, several counties and states in the U.S. have established effective barriers or enacted bans to prevent or limit the land application of biosolids, particularly Class B biosolids (Camp Dresser \& McKee, 2000). As a result, WRRFs across the U.S. are increasingly seeking to upgrade their Class B producing treatment process into one that produces Class A biosolids. Conventional processes for producing Class A biosolids include the processes to further reduce pathogens (PFRP) regulated by 40 CFR 257, which are composting, heat drying, heat treatment, thermophilic aerobic digestion, beta ray irradiation, gamma ray irradiation, or pasteurization. With the possible exception of composting, these are all expensive, high-maintenance processes, and most are energy intensive. Unfortunately, many WRRFs serving small communities (defined as having a population of $\leq 10,000$ people and wastewater flow rates of $<1 \times 10^{6}$ gal/day (USEPA 2012), lack the capital resources and personnel and other operating requirements for implementing a PFRP. Therefore, these WRRFs are interested in pursuing technologies that minimize the capital and O\&M costs associated with biosolids production, as well as the environmental impacts (Becker and Seagren 2018). Fortunately, low-cost, low-technology (LCLT) alternatives are available and being used successfully at WRRFs in the U.S. and elsewhere, as reviewed by Farrell et al. (2004), including long-term lagoon storage, air drying, combined lagoon storage/air drying, and cake storage.

This study compared five processes that can be used to produce Class A biosolids, including three conventional processes - composting, direct heat drying, and temperature-phased anaerobic digestion (TPAD) — and two LCLT processes - air drying, long-term lagoon storage followed by airy drying. For all five processes, the process is 
assumed to follow anaerobic digestion (with the exception of TPAD), and dewatering is assumed to be accomplished via a belt filter press. These processes were selected because they are representative of currently-used, popular processes based on the 2007 National Biosolids Regulation, Quality, End Use \& Disposal Survey conducted by the North East Biosolids \& Residuals Association (NEBRA) (Beecher, Crawford et al. 2007). The survey collected data from $50 \%$ of the wastewater treatment facilities on what treatment process they use and what criteria they meet. The most common dewatering technology is a belt filter press, which is estimated to be used by 650 plants to produce 415,000 dry tons per year (Beecher, Crawford et al. 2007). In addition, composting, digestion (TPAD), thermal (direct heat drying), and long-term storage (lagoon storage) were among the top six stabilization processes applied by survey participants.

Composting is a conventional process that utilizes aerobic conditions to enhance the biological degradation of the organic matter. The aerobic conditions created increase the temperature into the pasteurization range, destroy volatile solids, and increase the percent total solids (Metcalf and Eddy 2014). There are multiple types of direct heat dryers, which was the second conventional process examined, but this study focused on the rotary dryer. During direct heat drying, hot gases are used to remove water from the biosolids, which increases the percentage of total solids to $90-95 \%$ (Metcalf and Eddy 2014). The third conventional treatment process evaluated was temperature-phased anaerobic digestion (TPAD), which incorporates a mesophilic digestion stage and a thermophilic digestion stage. The combination of mesophilic and thermophilic decreases the solids retention time (SRT) and increases the efficiency of destroying volatile suspended solids (VSS) by 15-20\% more than can be accomplished with a single stage mesophilic digester (Metcalf and Eddy 2014).

Air drying is a LCLT process that is similar to windrow composting. Biosolids are placed on impervious or porous sand surfaces in windrows or laid flat where they are dried to $50-70 \%$ total solids (Farrell, Merrill et al. 2004). This study focused air drying biosolids in windrows on an impervious surface. Evaporation of water and degradation of organic solids occurs when mixing creates an aerobic environment. The second LCLT process evaluated was long-term lagoon storage coupled with air drying. Lagoon storage holds biosolids for one or more years and allows the organic matter to decompose under a combination of aerobic and anaerobic conditions. This study specifically focused on a high solids sludge processing train (HSSPT) lagoon storage where mechanical dewatering of biosolids occurs before being placed in the lagoons. After removing biosolids from the lagoons, the biosolids are placed on air drying pads for ten weeks. In that time, the percent total solids reach 60\% (Farrell, Merrill et al. 2004).

In addition to being commonly used in current practice, the five stabilization processes included in the study were also selected because they incorporate three to five chemical, physical, or biological stressors that contribute to the destruction of pathogenic bacteria, viruses, protozoa, and worms (Table 1.2). Key stressors include irradiation, temperature, concentrating solids, time, $\mathrm{pH} /$ oxidation, ammonia, and desiccation (Smith and Reimers 2006). A process with too few stressors is dangerous to rely on for consistent pathogen destruction. 
Table 1.2. Stressors of each process. Adapted from: (Smith and Reimers 2006)

\begin{tabular}{|c|c|c|c|c|c|c|c|c|}
\hline Process & $\begin{array}{l}\text { \# of } \\
\text { stressors }\end{array}$ & Irradiation & Temperature & $\begin{array}{l}\text { Solids } \\
\text { Conc. }\end{array}$ & Ammonia & $\begin{array}{l}\text { Organic } \\
\text { By- } \\
\text { products } \\
\text { (Volatile } \\
\text { Acids) }\end{array}$ & Drying & $\begin{array}{l}\text { Cavitation } \\
\text { /ultrasound }\end{array}$ \\
\hline $\begin{array}{l}\text { Lagoon } \\
\text { Storage }\end{array}$ & 4 & - & + & + & + & + & - & - \\
\hline Air Drying & 4 & + & + & + & - & - & + & - \\
\hline $\begin{array}{l}\text { Heat } \\
\text { Drying }\end{array}$ & 4 & + & + & + & - & - & + & - \\
\hline TPAD & 5 & - & + & + & + & + & - & + \\
\hline Composting & 5 & - & + & + & + & + & + & - \\
\hline
\end{tabular}

\subsection{Scope and Objectives}

Much is known regarding the technical aspects of the conventional and LCLT processes selected for this study, such as their ability to inactive pathogens. However, small WRRFs that are looking to make the upgrade from Class B to Class A biosolids production are not only concerned with the technical aspects of the processes. Rather, they also need to consider the environmental, economic, and social factors.

Therefore, the overall goal of this study was to quantify and compare the environmental, economic, and social impacts of the selected three conventional and two LCLT processes for producing Class A biosolids. Specifically, the objectives of this study were to: (1) characterize the environmental impacts associated with selected Class A biosolids producing processes by conducting a life-cycle assessment (LCA) study; (2) quantify the economic impacts of each process by a cost analysis that includes the capital costs and operational and maintenance (O\&M) costs; and (3) determine the positive and negative social impacts of each process by reviewing case studies, news articles, surveys, and online blogs. The results of this evaluation provide insight into the sustainability of each process, which in turn can be used to provide guidance for WRRFs in their decisionmaking process for choosing a technology to produce Class A biosolids. 


\section{Methodology}

\subsection{Environmental Impacts}

Knowing the environmental impacts allows for more informed decision-making in consideration of picking a treatment process. To characterize the environmental impacts associated with the five biosolids producing technologies selected for study, an LCA study was conducted. LCA is a method to assess all environmental impacts in all stages within the system boundaries that is becoming widely used in a variety of industries and settings. All LCA work completed in this research was compliant with International Organization for Standardization (ISO) 14044 (ISO 2006), which provides flexible, yet consistent standards that have been developed to ensure that LCA studies are done in a comprehensive and transparent manner.

\subsubsection{Goal, Scope, and Functional Unit}

LCAs in this study were conducted using the software SimaPro (PRé Consultants, version 8.0.3.14). The goal of these LCAs was to quantify the environmental impacts of each of the selected biosolids producing processes using the IMPACT 2002+ method (Jolliet, Margni et al. 2003). In particular, the focus of the LCA analyses was on distinguishing what the environmental impacts are and their respective sources. This evaluation was performed by determining the percentage of impacts from fuel, material inputs, infrastructure, and biogenic sources as well as the composition of biogenic emissions.

In terms of scope, this was a gate-to-gate study, which means the LCA includes the materials for each process contributing to the production and transportation of Class A biosolids. However, the beginning and end stages of life were not considered. For example, due to the scope of the study, the land application of biosolids was not included in the scope.

The functional unit used in this study was an annual biosolids the production of 200 dry tons of finished biosolids at the end of each process. This functional unit is typical of a small WRRF, which is the focus of this study, and is representative of the purpose of each treatment process.

System boundaries define the inputs and outputs of each process, and as well as which unit processes are included in the LCA. As illustrated in Figure 2.1, in this study, the system boundaries for all processes begin after anaerobic digestion at the WRRF where biosolids are initially generated, and end with the transportation of final Class A product to a final land application site. 


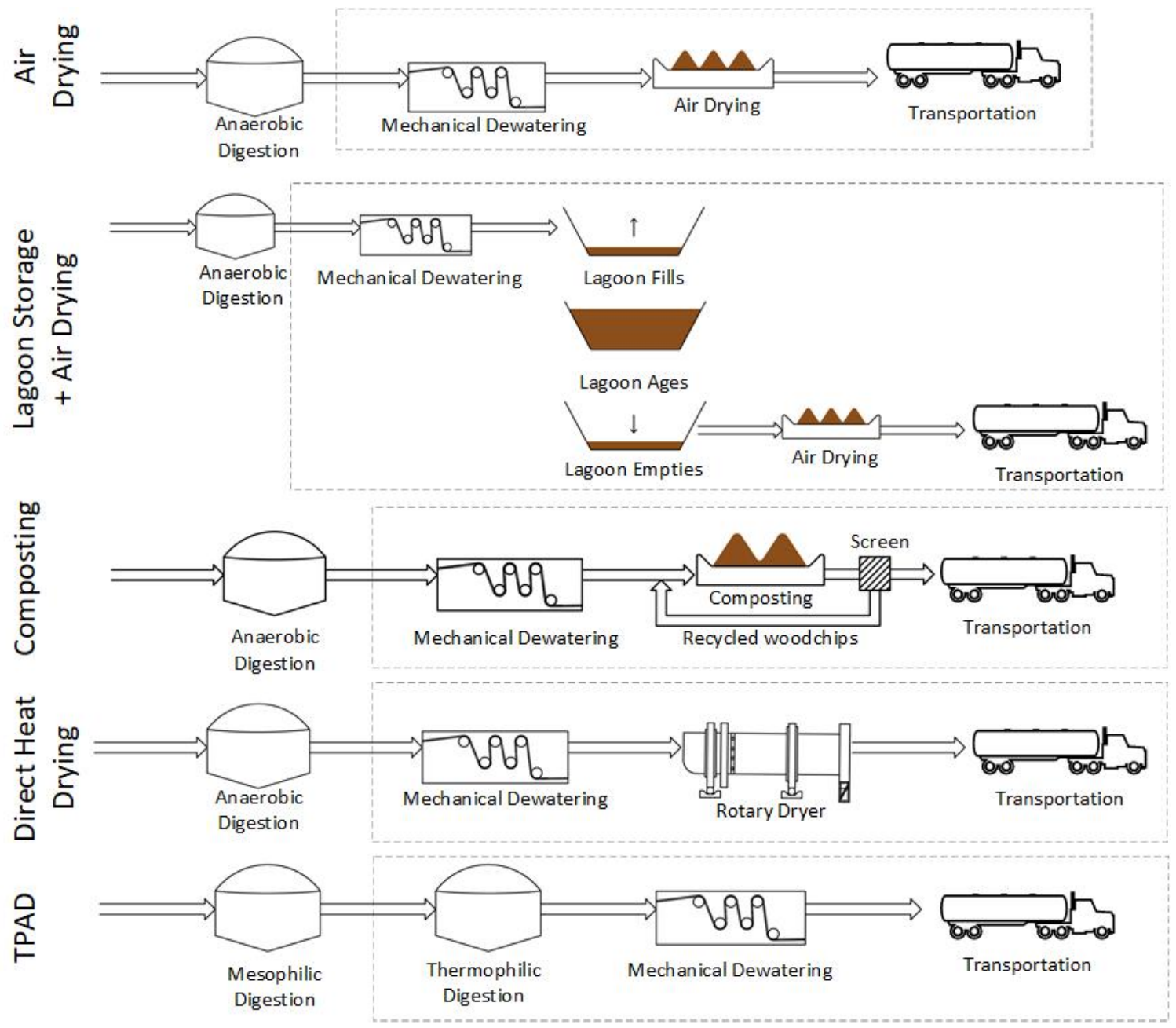

Figure 2.1. System boundaries for each treatment process. Dashed line represents system boundaries.

\subsubsection{SimaPro Methods}

SimaPro's IMPACT 2002+ method was utilized to calculate the environmental impacts of each process. IMPACT $2002+$ uses midpoint indicators that are then linked to damage categories (Jolliet, Margni et al. 2003), as summarized in Table 2.1. The midpoint indicators are normalized and weighed so the damage categories can be interpreted. The four damage categories are further aggregated into a single, final measure of environmental harm. The endpoint indicator is in the units of "point" which is equal to "pers*yr" (Humbert, Schryver et al. 2014). A point is the average impacts in each damage category caused by a person during one year in Europe (Humbert, Schryver et al. 2014). 
Table 2.1. IMPACT 2002+ indicators and damage categories. Source: SimaPro

\begin{tabular}{|c|c|c|}
\hline Midpoint Indicators & Damage Category & Endpoint Indicator \\
\hline Carcinogens $\left(\mathrm{kg} \mathrm{C}_{2} \mathrm{H}_{3} \mathrm{Cl} \mathrm{eq}\right)$ & \multirow{6}{*}{$\begin{array}{l}\text { Human Health } \\
\text { (DALY) }\end{array}$} & \multirow{13}{*}{$\begin{array}{l}\text { Point (pt), or person- } \\
\text { year } \\
\text { (Sum of normalized } \\
\text { damage categories } \\
\text { weighed equally. Not } \\
\text { weighed equally if } \\
\text { there are available } \\
\text { social weight values. } \\
\text { Single score for } \\
\text { environmental impacts) }\end{array}$} \\
\hline Non-Carcinogens $\left(\mathrm{kg} \mathrm{C}_{2} \mathrm{H}_{3} \mathrm{Cl}\right.$ eq) & & \\
\hline Respiratory inorganics $\left(\mathrm{kg} \mathrm{PM}_{2.5} \mathrm{eq}\right)$ & & \\
\hline Ionizing Radiation (Bq C-14 eq) & & \\
\hline $\begin{array}{l}\text { Ozone layer depletion (kg CFC-11 } \\
\text { eq) }\end{array}$ & & \\
\hline Respiratory organics $\left(\mathrm{kg} \mathrm{C}_{2} \mathrm{H}_{4} \mathrm{eq}\right)$ & & \\
\hline Aquatic ecotoxicity (kg TEG water) & \multirow{4}{*}{$\begin{array}{l}\text { Ecosystem quality } \\
\left(\mathrm{PDF}^{*} \mathrm{~m}^{2 *} \mathrm{yr}\right)\end{array}$} & \\
\hline Terrestrial ecotoxicity (kg TEG soil) & & \\
\hline Terrestrial acid/nutria $\left(\mathrm{kg} \mathrm{SO}_{2}\right.$ eq) & & \\
\hline Land occupation ( $\mathrm{m}^{2}$ org.arable) & & \\
\hline Global warming ( $\left.\mathrm{kg} \mathrm{CO}_{2} \mathrm{eq}\right)$ & $\begin{array}{l}\text { Climate change }(\mathrm{kg} \\
\mathrm{CO}_{2} \text { eq) }\end{array}$ & \\
\hline Non-renewable energy (MJ primary) & \multirow{2}{*}{$\begin{array}{l}\text { Resources (MJ } \\
\text { primary) }\end{array}$} & \\
\hline Mineral extracti & & \\
\hline
\end{tabular}

In this study, the IMPACT 2002+ method was modified to better represent the goal of the study. Specifically, the global warming potentials (GWP) used in IMPACT 2002+ are the 500-year time horizon GWPs from the Intergovernmental Panel on Climate Change (IPCC). However, due to this study's focus on more immediate decisions that can affect sustainability, a smaller time horizon was deemed more appropriate. Therefore, the GWPs were modified to include the 100-year time horizon GWP reported by IPCC's Fifth Assessment Report. As a result, the GWP for methane increased from 10.35 to 28, and the GWP for nitrous oxide increased from 156 to 256 (Myhre, Shindell et al. 2013).

\subsubsection{Input and output data for each biosolids production process}

Inventories of inputs and outputs were created for each process in preparation for the SimaPro analysis. Detailed calculations are shown in the Appendix. Unless otherwise noted, all input data came from the Ecoinvent version 3 database that is available within the SimaPro LCA modeling software (Weidema, Bauer et al. 2013).

Importantly, each process assumes a slightly different mass flow of material through the process to end with the common functional unit of 200 dry tons of biosolids produced annually (Figure 2.2). This is due to the differences in volatile solids destruction throughout the process trains, and the addition of the carbon source and bulking agent amendments in the composting process (Figure 2.2). 


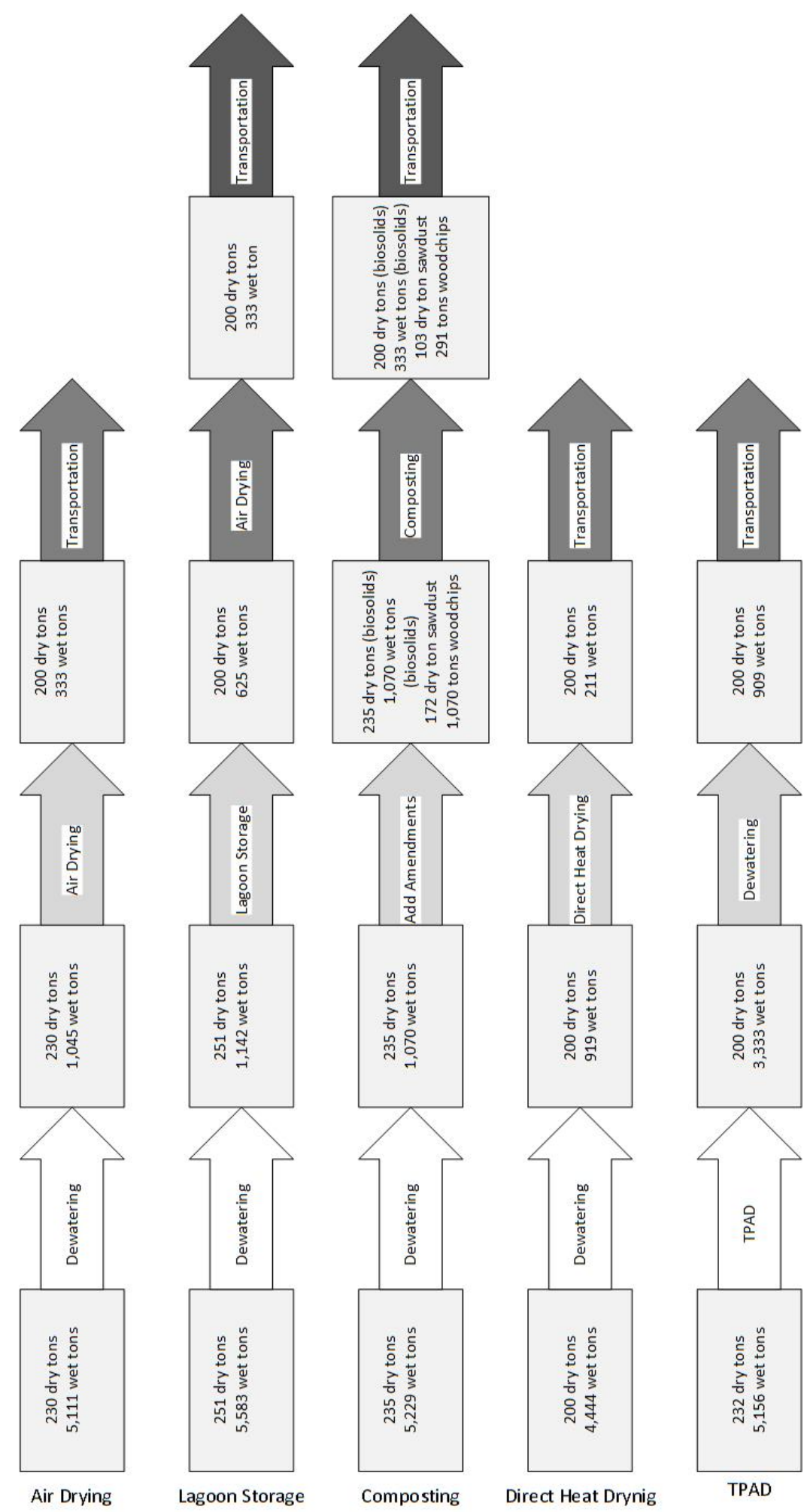

Figure 2.2. Mass flow through the process trains. Rectangles represent the mass at each process. The arrows represent the unit processes 


\subsubsection{Air Drying}

The inputs and outputs for air drying are summarized in Table 2.2. The inputs that had to be added included dewatering electricity, polymer, and water, the wastewater to be treated, diesel fuel for operating equipment, asphalt for the air drying pad, and transportation of the treated biosolids. Air drying begins with a belt filter press which increases the biosolids to $22 \%$ total solids. The belt filter press requires the addition of a water-soluble polymer to increase the performance of mechanical dewatering by flocculating suspended solids and colloidal material (Metcalf and Eddy 2014). The most commonly used polymers in mechanical dewatering are cationic polyacrylamide (PAM) polymers. The material libraries in SimaPro do not include PAM. Acrylonitrile was chosen to represent PAM because it is used to manufacture acrylamide (Hospido, Moreira et al. 2005). Electricity required for dewatering was calculated using the EPA's Handbook for estimating sludge management costs (USEPA 1985). The handbook incorporates an algorithm to determine the amount of total electricity that is needed to run a belt filter press. The amount of electricity is dependent on the belt filter width which was calculated using the dry solids loading rate. The algorithm is shown below.

\section{Electricity $=\left[-5.42(\mathrm{TBFW})^{3}+234.6(\mathrm{TBFW})^{2}+16,020(\mathrm{TBFW})+13,997\right]$ (USEPA 1985)}

$\mathrm{TBFW}=$ total belt filter width

Table 2.2. Air drying table of inputs and outputs. [a] $=1 \mathrm{~kg}$ of asphalt includes $0.1 \mathrm{~kg}$ of bitumen adhesive compound, hot $\{\mathrm{GLO}\} \mid$ market for|, $0.9 \mathrm{~kg}$ of gravel, crushed $\{\mathrm{GLO}\} \mid$ market for|, and $0.0013 \mathrm{kWh}$ of Diesel, burned in building machine

\begin{tabular}{|llll|}
\hline Parameter & Value & Unit & Ecoinvent Name \\
\hline Inputs & & & \\
\hline Dewatering Electricity & 8,618 & $\mathrm{kWh}$ & Electricity, medium voltage, at grid \\
\hline Dewatering Polymer & 2,760 & $\mathrm{lb}$ & Acrylonitrile $\{\mathrm{GLO}\} \mid$ market for \\
\hline Dewatering Water & 5,490 & $\mathrm{lb}$ & Tap water, at user \\
\hline Wastewater to be treated & 7,578 & $\mathrm{lb}$ & $\begin{array}{l}\text { Treatment, sewage, unpolluted, at to } \\
\text { wastewater treatment, class 3 }\end{array}$ \\
\hline Diesel Fuel & 1,344 & $\mathrm{lb}$ & Diesel, at regional storage \\
\hline Asphalt & 119,319 & $\mathrm{lb}$ & Asphalt \\
\hline Transportation of final product & 48,664 & $\mathrm{tkm}$ & Transport, lorry 16-32t, EURO3 \\
\hline Outputs & & & \\
\hline $\mathrm{CO}_{2}$, biogenic & 119,619 & $\mathrm{~kg}$ & Carbon Dioxide \\
\hline $\mathrm{CH}_{4}$, biogenic & 3,107 & $\mathrm{~kg}$ & Methane \\
\hline $\mathrm{N}_{2} \mathrm{O}$, biogenic & 54 & $\mathrm{~kg}$ & Nitrous Oxide \\
\hline $\mathrm{CO}_{2}$, fuel combustion & 4,270 & $\mathrm{~kg}$ & Carbon Dioxide \\
\hline
\end{tabular}


There are three sources of wastewater from a belt filter press to be treated: (1) water for cleaning the belt, (2) water to dilute the dry polymer to $0.5 \%$, and (3) water removed from the biosolids. The LCA includes the inputs associated with treatment of this wastewater within a small WRRF.

Diesel fuel is needed to transport the biosolids from the belt filter press to the air drying pad in a dump truck, form windrows with a front-end loader, and mix the windrows each week. To make these calculations, it was assumed that the air drying pad is 2,000 $\mathrm{ft}$ away from the belt filter press. The diesel fuel requirement for the windrow mixing equipment came from Komilis and Ham (2004). It was assumed that the windrows were mixed once a week by a windrow turner machine. The transportation to the air drying pad diesel consumption was estimated using the distance, driving speed, and fuel consumptions. Fossil carbon dioxide emissions were inputted in SimaPro to account for the burning of diesel fuel. The quantity of carbon dioxide released was calculated with the formula below which accounts for complete stoichiometric combustion of the diesel fuel.

$\mathrm{CO}_{2}$ emissions $(\mathrm{kg})=3.2 *$ diesel fuel $(\mathrm{kg})$

The impervious surface used for air drying is assumed to be an asphalt mixture of $10 \%$ bitumen and 90\% gravel. The energy required to pave the pad was estimated using paving equipment data ( $\mathrm{Li}$, Zhang et al. 2016). The quantity of asphalt was determined by calculating the size of the impervious pad needed to accommodate the volume of biosolids in windrows. The assumed depth of asphalt was 0.5 feet. It was assumed the lifetime of the asphalt pad is 25 years. The environmental impacts were distributed to the biosolids produced within the lifetime of the pad.

The outputs included are biogenic emissions $\left(\mathrm{CO}_{2}, \mathrm{CH}_{4}, \mathrm{~N}_{2} \mathrm{O}\right)$, and $\mathrm{CO}_{2}$ from fuel combustion. The biogenic emissions from air drying are not well reported in the prior literature on this process. Therefore, a sensitivity analysis was conducted to illustrate the impacts of uncertainty in this key emissions data. For this analysis, the percentage of the initial biosolids carbon emitted as methane, and the percentage of initial biosolids nitrogen emitted as nitrous oxide, was altered for three scenarios. In Scenario 1, the percentage of initial carbon emitted as methane and the percentage of initial nitrogen emitted as nitrous oxide was increased based on Yamulki's (2006) findings. Yamulki (2006) studied the percent decrease of $\mathrm{CH}_{4}$ and $\mathrm{N}_{2} \mathrm{O}$ emissions when straw was added to manure farmyard piles to achieve a more desirable $\mathrm{C} / \mathrm{N}$ ratio. The percent change was calculated and applied to the percentages of emissions used in the composting process where nutrient amendments are used for this same effect. Scenario 3 applied the same emissions data used in the composting process, to simulate a case where lots of aerobic activity is happening in the air drying pile. Scenario 2 was an intermediate case between Scenario 1 and Scenario 3. Compared to composting, the air drying process has a lower $\mathrm{C} / \mathrm{N}$ ratio and less aeration due to less mixing. The $\mathrm{C} / \mathrm{N}$ ratio for digested solids is 15.7 , and the percent nitrogen is $1.88 \%$ (Seagren 2019). A small $\mathrm{C} / \mathrm{N}$ ratio results in higher emissions of $\mathrm{CH}_{4}$ and $\mathrm{N}_{2} \mathrm{O}$ (Brown, Kruger et al. 2008). The emissions for each scenario are shown in Table 2.3. 
Table 2.3. Air drying emissions for sensitivity analysis

\begin{tabular}{|l|l|l|}
\hline Scenario & Methane & Nitrous Oxide \\
\hline $\begin{array}{l}\text { Scenario 1 - Conservative } \\
\text { (baseline) }\end{array}$ & $3.8 \%$ of initial carbon & $0.87 \%$ of initial nitrogen \\
\hline Scenario 2 - Intermediate & $2.85 \%$ of initial carbon & $0.74 \%$ of initial nitrogen \\
\hline $\begin{array}{l}\text { Scenario 3 - Similar to } \\
\text { Composting }\end{array}$ & $1.9 \%$ of initial carbon & $0.60 \%$ of initial nitrogen \\
\hline
\end{tabular}

Transportation of 50 miles to the land application site is also included as an output within the boundary in each case to show the effects of the percent solids of the end product and the addition of amendments. There is no standard distance for transporting biosolids, and it may range widely. For example, the Portage Lake Water \& Sewage Authority in Houghton, Michigan transports their biosolids approximately 10 miles one way to Mason, MI. In comparison, utilities in California transports their biosolids hundreds of miles to Arizona, Nevada, and Oregon (SCAP 2016) to be applied to land, landfilled or composted. To examine the impact of these variation in transportation distances on the LCA results, a sensitivity analysis was conducted using 10, 50, 100, and 200 miles as one-way distances, although in the analysis the full round-trip distances are used.

\subsubsection{Lagoon Storage plus Air Drying}

The inputs and outputs for lagoon storage are presented in Table 2.4. In the lagoon storage case, mechanical dewatering with a belt filter press occurs first, which includes similar inputs and outs as the air drying mechanical dewatering: dewatering electricity, polymer and water, and the wastewater to be treated. The slight differences in inputs are a result of different amounts of solids at this stage in the process. After the belt filter press, the $22 \%$ total solids biosolids are transported by a diesel dump truck 2,000 feet to the lagoons. The dump truck places the biosolids next to the lagoons where a front-end loader then distributes the biosolids in the lagoon.

The lagoons are assumed to be constructed using clay and a 40 mil. HDPE liner. The quantities of clay and HDPE were determined by sizing the lagoons for the volume of biosolids. The clay is assumed to have a thickness of 0.5 feet, a biosolids depth of 5 feet, and a freeboard of 2 feet. The soil excavated for the lagoons were assumed to have a useful purpose on the site such as building berms, so no off-site soil transportation was included.

After two years of storage, the biosolids are removed by a front-end loader and transported 500 feet to the air drying pad. Once at the pad, the biosolids are formed into small windrows and mixed periodically for about ten weeks. Assuming all Class A standards are met, the biosolids are then transported to their final destination. The quantity of diesel fuel used in the process was estimated using the assumed distances and time and the equipment manufacturer's information. 
Table 2.4. Lagoon storage table of inputs and outputs. [a] $=1 \mathrm{~kg}$ of asphalt includes 0.1 $\mathrm{kg}$ of bitumen adhesive compound, hot $\{\mathrm{GLO}\} \mid$ market for $\mid, 0.9 \mathrm{~kg}$ of gravel, crushed

$\{\mathrm{GLO}\} \mid$ market for|, and $0.0013 \mathrm{kWh}$ of Diesel, burned in building machine

\begin{tabular}{|c|c|c|c|}
\hline Parameter & Value & Unit & Ecoinvent Name \\
\hline \multicolumn{4}{|l|}{ Inputs } \\
\hline Dewatering Electricity & 8,618 & $\mathrm{kWh}$ & $\begin{array}{l}\text { Electricity, medium } \\
\text { voltage, at grid }\end{array}$ \\
\hline Dewatering Polymer & 3,015 & $\mathrm{lb}$ & $\begin{array}{l}\text { Acrylonitrile }\{\mathrm{GLO}\} \mid \\
\text { market for } \mid\end{array}$ \\
\hline Dewatering Water & 5,503 & $\mathrm{lb}$ & Tap water, at user \\
\hline Wastewater to be treated & 7,784 & $\mathrm{lb}$ & $\begin{array}{l}\text { Treatment, sewage, } \\
\text { unpolluted, at to } \\
\text { wastewater treatment, } \\
\text { class } 3\end{array}$ \\
\hline Diesel Fuel & 1,163 & $\mathrm{lb}$ & $\begin{array}{l}\text { Diesel, at regional } \\
\text { storage }\end{array}$ \\
\hline Clay & 119,587 & $\mathrm{lb}$ & Clay $\{\mathrm{GLO}\} \mid$ market for \\
\hline HPDE Liner & 507 & $\mathrm{lb}$ & HDPE resin E \\
\hline Asphalt & 177,176 & $\mathrm{lb}$ & Asphalt $^{\mathrm{a}}$ \\
\hline Transportation of final product & 48,664 & tkm & $\begin{array}{l}\text { Transport, lorry 16-32t, } \\
\text { EURO3 }\end{array}$ \\
\hline \multicolumn{4}{|l|}{ Outputs } \\
\hline $\mathrm{CO}_{2}$, biogenic & 207,370 & $\mathrm{~kg}$ & Carbon Dioxide \\
\hline $\mathrm{CH}_{4}$, biogenic & 1,926 & $\mathrm{~kg}$ & Methane \\
\hline $\mathrm{N}_{2} \mathrm{O}$, biogenic & 885 & $\mathrm{~kg}$ & Nitrous Oxide \\
\hline $\mathrm{CO}_{2}$, fuel combustion & 3720 & $\mathrm{~kg}$ & Carbon Dioxide \\
\hline
\end{tabular}

With respect to outputs, the biogenic emissions from the lagoons were estimated by using a study that looked at the emissions produced by rectangle stockpiles of biosolids (Majumder, Livesley et al. 2014). The emissions were given in the units of $\mathrm{kg} \mathrm{CO} 2$-eq $\mathrm{Mg}^{-1}$ year-1. If the quantity of biosolids and the time spent in the lagoons are known, then the emissions could be estimated. The middle age lagoon emissions (1-3 years old) from Majumder et al. (2014) were used to represents part of the first year of storage, the second year of storage, and the two months used for removing the biosolids from the lagoons. The young lagoon emissions ( $<1$-year-old) from Majumder et al. (2014) were used to represents the lagoon during six months of it getting filled, and part of the first year of storage.

Unfortunately, the treatment process preceding the long term storage of biosolids in the Majumder et al. (2014) article is different from the process being model in this study. The WRRF in the study by Majumder et al. (2014) places the biosolids on air drying pans rather than putting them into lagoon first. The air drying process allows the biosolids to lose carbon, nitrogen, and moisture. Despite these differences in study conditions, this article's data are the best available data, so it was still used in this study. 
To produce 200 dry tons of final biosolids each year, a WRRF requires four lagoons and an air-drying pad, as presented in Figure 2.3. As illustrated, once all four lagoons are in operation, there is one lagoon is in the filling phase with dewatered biosolids being continually added for six to nine months, two lagoons are in the storage phase for a total of two years, and one lagoon from which the biosolids are being removed for two months. Once removed from the lagoon, the biosolids are placed on an air-drying pad for ten weeks. Having four lagoons optimizes the process by allowing for the continuous production of Class A biosolids. The emissions from all four stages must be included in the LCA to satisfy the functional unit.

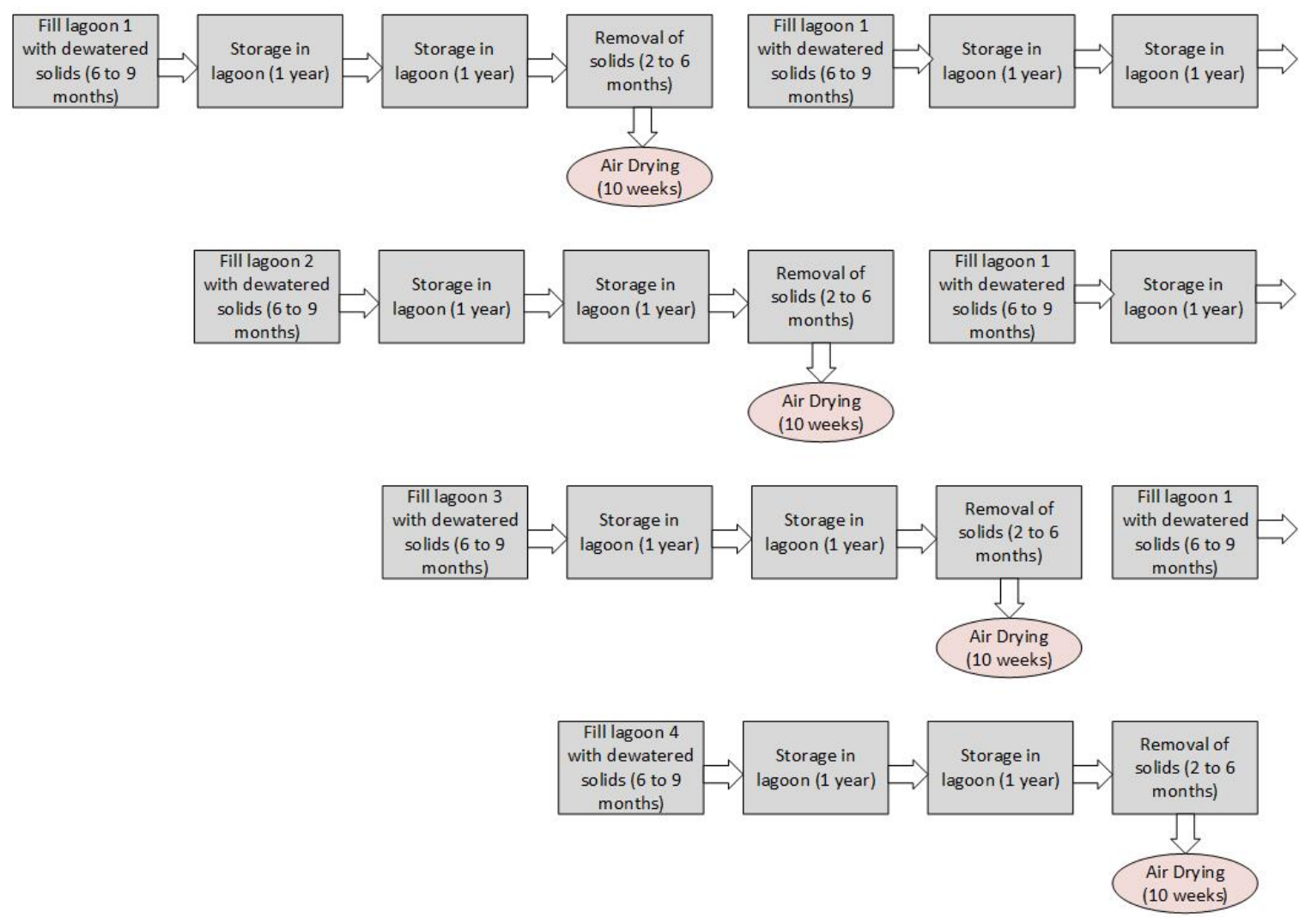

Figure 2.3. Lagoon management scheme with storage time required

Typically, placing and removing biosolids from a lagoon requires a trailer-mounted agitation pump or some crane system such as the one used at the West-Southwest Sewage Treatment Works in Chicago (USEPA 1974). The use of front-end loaders is generally discouraged because they can damage the lagoon liners. However, the pump or crane system could not be accurately portrayed in SimaPro, so it was assumed a front-end loader was used to represent the energy consumption for biosolids removal.

The air drying aspect of the lagoon storage process has similar inputs and outputs as the regular air drying process. The distance from the lagoon to the air drying pad was 
assumed to be 500 feet. The size of the pad is different from the air drying alone because the percent solids after lagoon storage is higher, but the biogenic emissions are assumed to have the same level of intensity as the direct air drying process. Transportation of the final product includes 200 dry tons of biosolids at $60 \%$ total solids.

\subsubsection{Composting}

The inputs and outputs for composting are described in Table 2.5. As with other processes, the composting process begins with mechanical dewatering using a belt filter. The inputs and outputs of mechanical dewatering are similar to the other processes, but vary slightly due to solids concentration at that point in the process. The biosolids are then transported via dump truck to the composting pad.

Table 2.5. Composting table of inputs and outputs. [a] $=1 \mathrm{~kg}$ of asphalt includes $0.1 \mathrm{~kg}$ of bitumen adhesive compound, hot $\{\mathrm{GLO}\}$ | market for|, $0.9 \mathrm{~kg}$ of gravel, crushed

$\{\mathrm{GLO}\} \mid$ market for|, and $0.0013 \mathrm{kWh}$ of Diesel, burned in building machine

\begin{tabular}{|c|c|c|c|}
\hline Parameter & Value & Unit & Ecoinvent Name \\
\hline \multicolumn{4}{|l|}{ Inputs } \\
\hline Dewatering Electricity & 8,618 & $\mathrm{kWh}$ & $\begin{array}{l}\text { Electricity, medium voltage, at } \\
\text { grid }\end{array}$ \\
\hline Dewatering Polymer & 2,824 & lb & $\begin{array}{l}\text { Acrylonitrile }\{\mathrm{GLO}\} \mid \text { market } \\
\text { for } \mid\end{array}$ \\
\hline Dewatering Water & 5,493 & lb & Tap water, at user \\
\hline Wastewater to be treated & 7,629 & lb & $\begin{array}{l}\text { Treatment, sewage, unpolluted, } \\
\text { at to wastewater treatment, } \\
\text { class } 3\end{array}$ \\
\hline Wood Chips & $1,077,099$ & $1 b$ & $\begin{array}{l}\text { Waste wood chips, mixed, } \\
\text { from industry, } u=40 \% \text {, at plant }\end{array}$ \\
\hline Sawdust & 526,141 & $1 b$ & $\begin{array}{l}\text { Sawdust, from dried lumber, at } \\
\text { planer mill, US PNW/kg }\end{array}$ \\
\hline Diesel Fuel & 3,277 & lb & Diesel, at regional storage \\
\hline Trommel Screen Electricity & 1,169 & $\mathrm{kWh}$ & $\begin{array}{l}\text { Electricity, medium voltage, at } \\
\text { grid }\end{array}$ \\
\hline Asphalt & 115,045 & $1 \mathrm{~b}$ & Asphalt $^{\mathrm{a}}$ \\
\hline $\begin{array}{l}\text { Transportation of final } \\
\text { product }\end{array}$ & 141,286 & $\mathrm{tkm}$ & $\begin{array}{l}\text { Transport, lorry 16-32t, } \\
\text { EURO3 }\end{array}$ \\
\hline \multicolumn{4}{|l|}{ Outputs } \\
\hline $\mathrm{CO}_{2}$, biogenic & 146,611 & $\mathrm{~kg}$ & Carbon Dioxide \\
\hline $\mathrm{CH}_{4}$, biogenic & 1,838 & $\mathrm{~kg}$ & Methane \\
\hline $\mathrm{N}_{2} \mathrm{O}$, biogenic & 23 & $\mathrm{~kg}$ & Nitrous Oxide \\
\hline $\mathrm{CO}_{2}$, fuel combustion & 10,486 & $\mathrm{~kg}$ & Carbon Dioxide \\
\hline
\end{tabular}

Composting is similar to air drying regarding the use of windrows on an impervious surface. However, composting utilizes both nutrient and structural amendments to increase the $\mathrm{C} / \mathrm{N}$ ratio and to increase the stability of the windrows, respectively. Sawdust is added to the biosolids to increase the $\mathrm{C} / \mathrm{N}$ ratio to 30 from 15.7. Woodchips were 
added as a bulking agent to allow for bigger, more stable windrows and increased aeration. The woodchips were added on a 2:1 volume ratio to biosolids (Wang, Shammas et al. 2007). It was assumed that the woodchips are strictly a structural amendment and do not contribute any nutrients to the composting process.

The composting asphalt pad is assumed to be constructed using the same mixture as the air drying's impervious surface, but there is a smaller quantity. The difference in quantity is because the windrows are double the height and don't take up as much room as the airdrying windrows. A front-end loader mixes the biosolids and amendments together and form windrows. After the compost is turned three times a week by a mechanical turner for 21 days, it cures in place for 30 days. After the 30 days, the compost is processed using a trommel screen, which is powered by electricity (Komilis and Ham 2004). The screen removes $70 \%$ of the woodchips, which can be reused in subsequent cycles (Spellman 1997). A front-end loader requires diesel fuel to move and mix the amendments and biosolids as well as moving the compost to the trommel screen.

The final input is transportation of the final product, which includes more than 200 dry tons of biosolids at $60 \%$ solids. It also includes the $30 \%$ of woodchips not screened out and the sawdust. It's assumed that the volume of sawdust decreases by $40 \%$ which matches the volume reduction of the biosolids (Metcalf and Eddy 2014).

With respect to outputs, the biogenic emissions were calculated using literature values. Specifically, it was assumed that the nitrogen is reduced by $33 \%$ (Poulsen and Hansen 2003), the carbon is reduced by 57\% (Tiquia, Richard et al. 2002), 1.9\% of initial carbon is released as methane (Brown, Kruger et al. 2008), and $0.6 \%$ of initial nitrogen is released as nitrous oxide (Brown, Kruger et al. 2008). It was assumed that the remaining amount of loss nitrogen is released in the form of ammonia. The detail calculations are in the Appendix.

\subsubsection{Direct Heat Drying}

The inputs and outputs for direct heat drying are summarized in Table 2.6. The direct heat drying process begins with a belt filter press where the inputs and outputs are similar to those in the processes above. The rotary dryer's only input is natural gas. The energy needed is 1,400 to 1,700 BTU per pound of water evaporated (USEPA 2006). It is possible to use other fuel sources besides natural gas like biogas from digesters and woodchips. If biogas is used, the environmental impacts are likely to decrease. The final biosolids end product is $95 \%$ solids which makes transportation have less of an impact. It was assumed that no destruction of volatile solids occurred in the rotary dryer. 
Table 2.6. Direct heat drying table of inputs and outputs

\begin{tabular}{|llll|}
\hline Parameter & Value & Unit & Ecoinvent Name \\
\hline Inputs & & & \\
\hline Dewatering Electricity & 8,618 & $\mathrm{kWh}$ & Electricity, medium voltage, at grid \\
\hline Dewatering Polymer & 2,400 & $\mathrm{lb}$ & Acrylonitrile \{GLO\}| market for $\mid$ \\
\hline Dewatering Water & 5,471 & $\mathrm{lb}$ & Tap water, at user \\
\hline Wastewater to be treated & 7,287 & $\mathrm{lb}$ & $\begin{array}{l}\text { Treatment, sewage, unpolluted, to } \\
\text { wastewater treatment, class 3 }\end{array}$ \\
\hline Natural Gas & 62,062 & $\mathrm{~m} 3$ & $\begin{array}{l}\text { Natural gas, combusted in industrial } \\
\text { boiler }\end{array}$ \\
\hline Transportation of final product & 30,735 & $\mathrm{tkm}$ & Transport, lorry 16-32t, EURO3 \\
\hline
\end{tabular}

\subsubsection{TPAD}

Inputs and outputs for the TPAD process are summarized in Table 2.7. TPAD is a multistage process that can be arranged with mesophilic digestion followed by thermophilic digestion (MT) or thermophilic digestion followed by mesophilic digestion (TM). By assuming that the process is mesophilic followed by thermophilic for this study, the system boundary does not include the mesophilic digestion and only includes the thermophilic digestion. In this way, it is then consistent with the other processes, which begin with solids coming from a mesophilic anaerobic digestion that can be excluded from the system boundaries in all of the processes.

TPAD uses mechanical dewatering like the other processes, but in this case it is after the primary process of TPAD. Nevertheless, the inputs of mechanical dewatering are similar to the processes reviewed above. The biosolids produced are $22 \%$ solids, which are relatively low compared to the other processes in the study. The low percentage of solids means there is more weight to transport.

Table 2.7. TPAD table of inputs and outputs

\begin{tabular}{|c|c|c|c|}
\hline Parameter & Value & Unit & Ecoinvent Name \\
\hline \multicolumn{4}{|l|}{ Inputs } \\
\hline Dewatering Electricity & 8,618 & $\mathrm{kWh}$ & $\begin{array}{l}\text { Electricity, medium voltage, at } \\
\text { grid }\end{array}$ \\
\hline Dewatering Polymer & 2,400 & $\mathrm{lb}$ & Acrylonitrile $\{\mathrm{GLO}\} \mid$ market for $\mid$ \\
\hline Dewatering Water & 5,471 & $\mathrm{lb}$ & Tap water, at user \\
\hline Wastewater to be treated & 6,716 & $1 \mathrm{~b}$ & $\begin{array}{l}\text { Treatment, sewage, unpolluted, at } \\
\text { to wastewater treatment, class } 3\end{array}$ \\
\hline TPAD Electricity & 17,401 & $\mathrm{kWh}$ & $\begin{array}{l}\text { Electricity, medium voltage, at } \\
\text { grid }\end{array}$ \\
\hline Transportation of final product & 132,719 & tkm & Transport, lorry 16-32t, EURO3 \\
\hline \multicolumn{4}{|l|}{ Outputs } \\
\hline Carbon Dioxide & 22,976 & $\mathrm{~kg}$ & Carbon Dioxide \\
\hline
\end{tabular}

Other inputs include electricity, which is necessary for pumping and mixing the thermophilic digester, and heat, which is required to heat the digester to the thermophilic 
temperature range. Consistent with previous LCAs, in this study it was assumed that the biogas produced from the digestion is sufficient for heating the digester (ANL 2018).

Once the biogas is used for combustion, the gas released to the atmosphere is assumed to be $99 \%$ carbon dioxide.

\subsection{Economic Impacts}

The economic impacts of each process were quantified by a cost analysis that includes the capital costs and operational and maintenance $(\mathrm{O} \& \mathrm{M})$ costs. The O\&M costs are a combination of labor, materials, and fuel needed to run each process. The EPA sludge management cost estimating guide was used to provide cost estimates for composting, transportation, mechanical dewatering, and land change construction (USEPA 1985). LCLT processes were more challenging to quantify labor and fuel use. Estimates for these processes were based on mixing requirements and the distances between unit processes.

For example, the labor requirements for air drying were calculated by using the EPA cost estimating handbook for the mechanical dewatering. Then, the distance to the air drying pad from the belt filter press and the speed of the dump truck were used to calculate the labor hours it took to transfer the biosolids to the air drying unit process. The time spent turning the windrows was calculated by knowing the number of times the windrows are turned, the rate of the turner, and the length and number of windrows. These calculations are provided in the Appendix 6.

Capital costs for the belt filter press, rotary dryer, and TPAD system were estimated using the EPA's fact sheets (USEPA 2006), (USEPA 2000), (USEPA 2006). The capital cost of the windrow turner was adjusted with inflation (UW-Madison 1996). The air drying, lagoon storage, and composting capital costs include the materials and construction of the impervious pads which includes site clearing, paving, gravel, liquid asphalt, and grading. Lagoon storage also included the construction and materials for the lagoons which included site clearing, liner installation, site grading, compaction, clay, HDPE liner, gravel, and liquid asphalt.

For all of the processes, it's assumed that the WRRFs were already producing biosolids and transporting them somewhere. Therefore, it was assumed that the WRRFs already have trucks for transportation and a front-end loader to move biosolids on site. It was also assumed that the composting and air drying processes are not performed under a cover, in a building, nor do they have an odor control system. No buildings were included for the air drying system. It was assumed that there was room in an existing building. TPAD systems can be purchased new or can be made by retrofitting existing digesters. It was assumed that a new TPAD system was bought.

\subsection{Social Impacts}

Social impacts of biosolids treatment processes are the most difficult to quantify, because the associated data are qualitative. For this study, case studies, news articles, surveys, and 
online blogs were reviewed to determine the positive and negative social impacts of the biosolids processes. The case studies included the use of biosolids in Houghton, MI, Milwaukee, WI, Loudoun County, VA, and Seattle, WA. The survey used in this study was from two cities in southeastern United States and included questions on general knowledge of biosolids and the attitude towards biosolids end use.

Aesthetics and concern for human health and the environment represent the majority of the social impacts that were assessed in prior work (Robinson, Robinson et al. 2012), (Beecher, Crawford et al. 2007), (Vasileski 2007). Specifically, the impacts that were used in scoring the social impacts in this report were odor, noise, number of trucks, appearances, dust, and concern for human health and the environment. The impacts were assessed by giving each process a score for each of the impacts, with a higher score indicating a greater negative social impact.

The most offensive odors are a product of organic and inorganic forms of sulfur, mercaptans, ammonia, amines, and organic fatty acids and released when biosolids are heated, aerated, and digested (USEPA 2000). Dust can be produced when biosolids with a high percentage of total solids are stirred, moved or mixed. Processes that move higher $\%$ TS biosolids received a point. Processes with windrow turning and lots of movement of the biosolids on site were given higher scores for noise. The trucks rating was solely based on the volume of the final biosolids. The appearances were rated based on land use and visibility to the public. Finally, every process received a point for concern for human health and environment because the concern is not with the specific process, rather, it is with biosolids in general. However, it is important to note that each community is different and will respond differently to perceived impacts in any of these categories mentioned or have a different feeling towards biosolids in general. 


\section{Results and Discussion}

\subsection{Environmental}

The environmental impacts are the sum of the four damage categories: resources, climate change, ecosystem quality, and human health. Within each of the processes evaluated (Figure 3.1), climate change was the largest contributor to the overall environmental impact single score for all of the processes, with the exception of direct heat drying, for which resource use was the biggest contributor. Comparing the environmental impacts results between processes (Figure 3.1), composting was found to have the greatest environmental impacts at $70.3 \mathrm{pt}$ followed by direct heat drying and lagoon storage at $50.3 \mathrm{pt}$ and $39.3 \mathrm{pt}$, respectively. TPAD had the lowest overall environmental impact score of all of the processes, followed by air drying. A closer look at the score for each process revealed additional insights as discussed below. First the two LCLT processes are examined, followed by the three conventional processes.

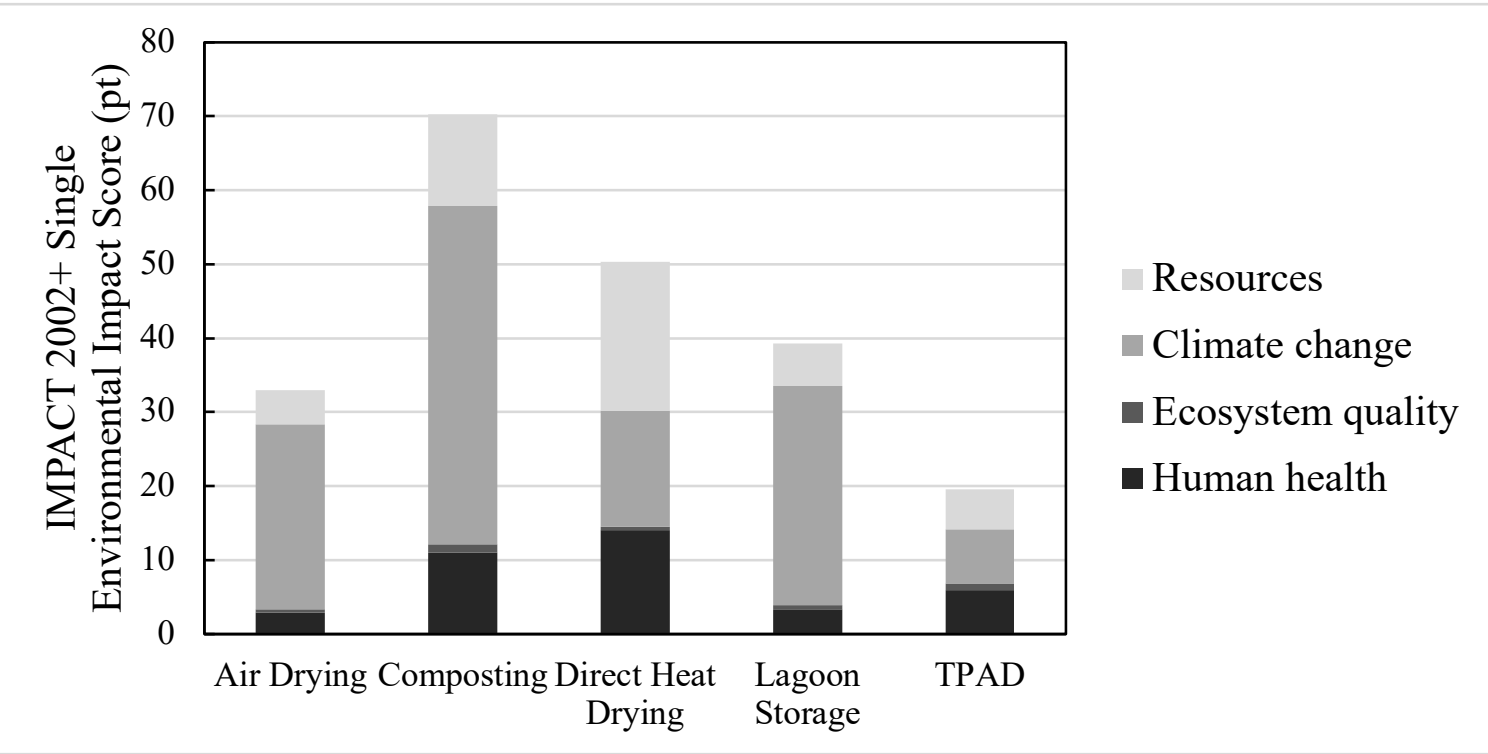

Figure 3.1. Overall environmental impacts for each processing using IMPACT 2002+ method. The different shades of gray represent the four damage categories.

\subsubsection{Air Drying Results}

The total environmental impacts single score for the LCLT technology of air drying is $32.9 \mathrm{pt}$, which was the next to lowest score. The majority of the environmental impacts for air drying come from the climate change category as shown in Figure 3.1. To understand this finding, the score for each of the damage categories produced by air drying's unit processes are displayed in Figure 3.2. Clearly, the air drying process itself, which includes placing biosolids in windrows and turning them once a week, contributes the most to climate change and resources. The biogenic emissions of carbon dioxide and 
methane account for $91 \%$ of the climate change category. In comparison, transportation contributes the most to human health and ecosystem quality.

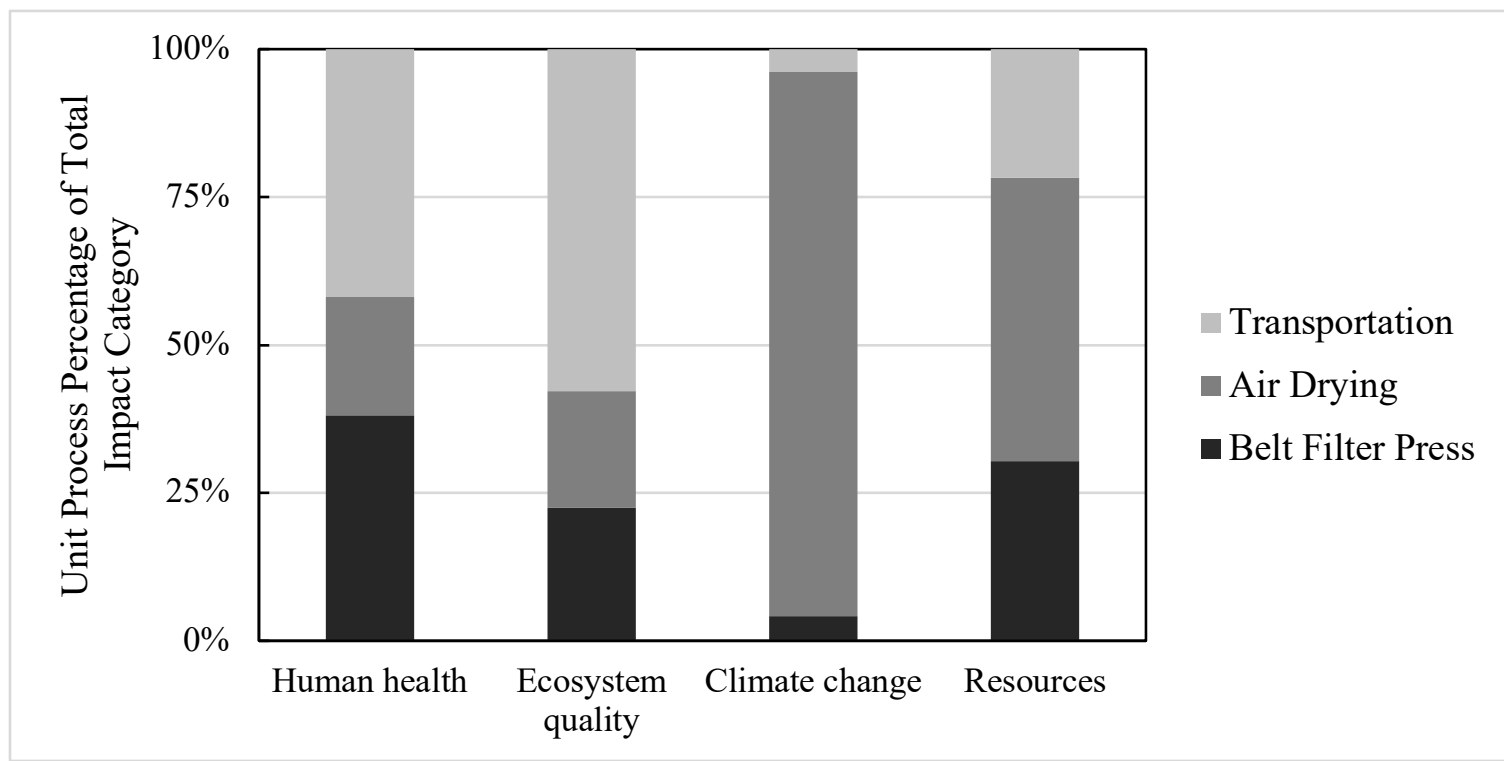

Figure 3.2. Environmental impacts of air drying unit processes

Air drying's environmental impacts were evaluated further to evaluate source of impacts presented in Figure 3.2, as shown in Figure 3.3. The four sources are assumed to be 'Utilities/Fuel', materials, biogenic, and infrastructure for each impact. Biogenic emissions obviously account for the majority of impacts, followed by utilizes/fuel, which represent the electricity required for dewatering and the diesel needed for moving and turning biosolids. 


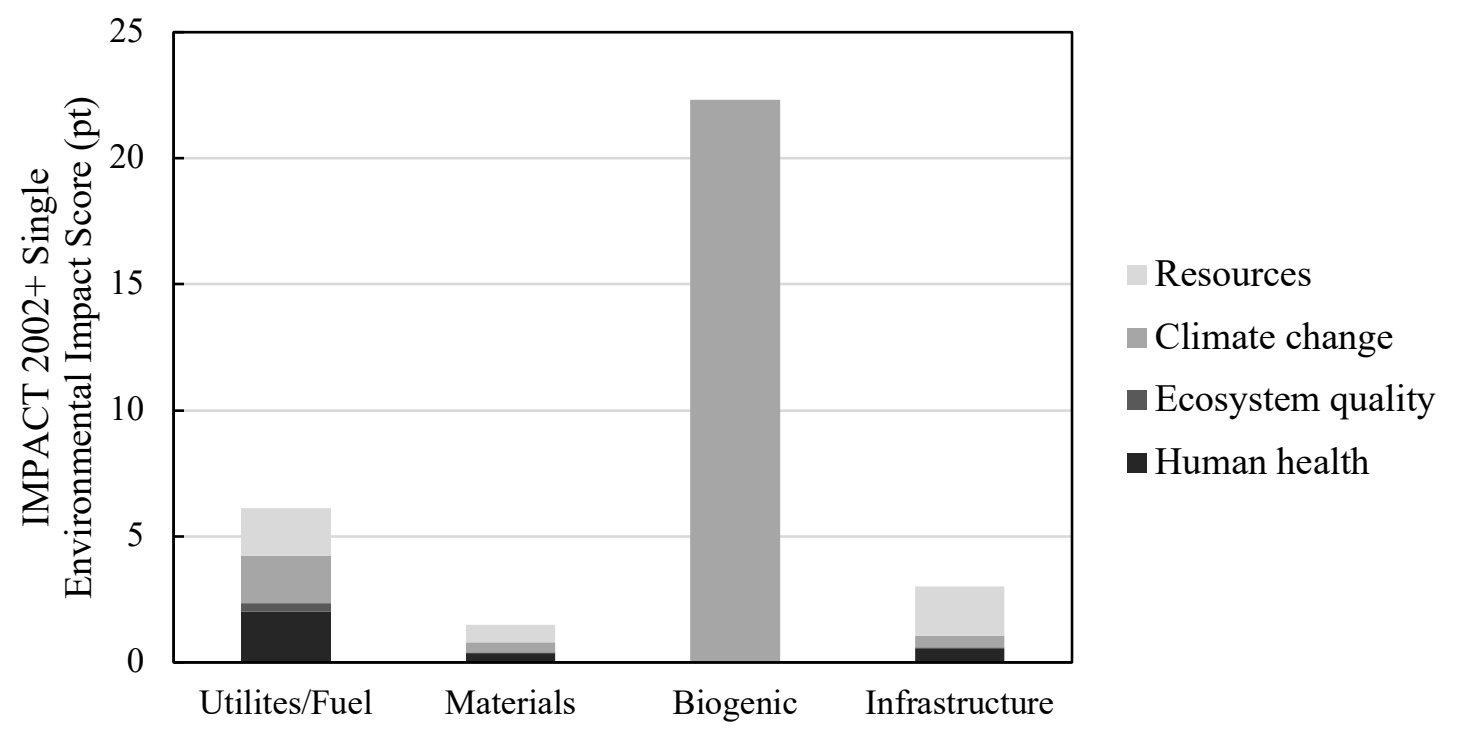

Figure 3.3. Environmental impacts of air drying separated by utilities/fuel, materials, biogenic, and infrastructure sources

\subsubsection{Sensitivity Analysis}

As mentioned in the methods, a sensitivity analysis was conducted on the emissions for air drying due to the lack of available data. The results of this sensitivity analysis are displayed in Figure 3.4 in terms of the total environmental impacts for the whole air drying process, as a function of the gas production assumptions. Altering the percentage of initial carbon and nitrogen released as methane and nitrous oxide created a potential range of final environmental impacts single score of $28.4 \mathrm{pt}$ to $32.9 \mathrm{pt}$. This range of values would not result in a change in the rankings of the processes, but it does highlight the importance of considering the range of potential impacts, and the need for further research in this area to quantify these emissions. 


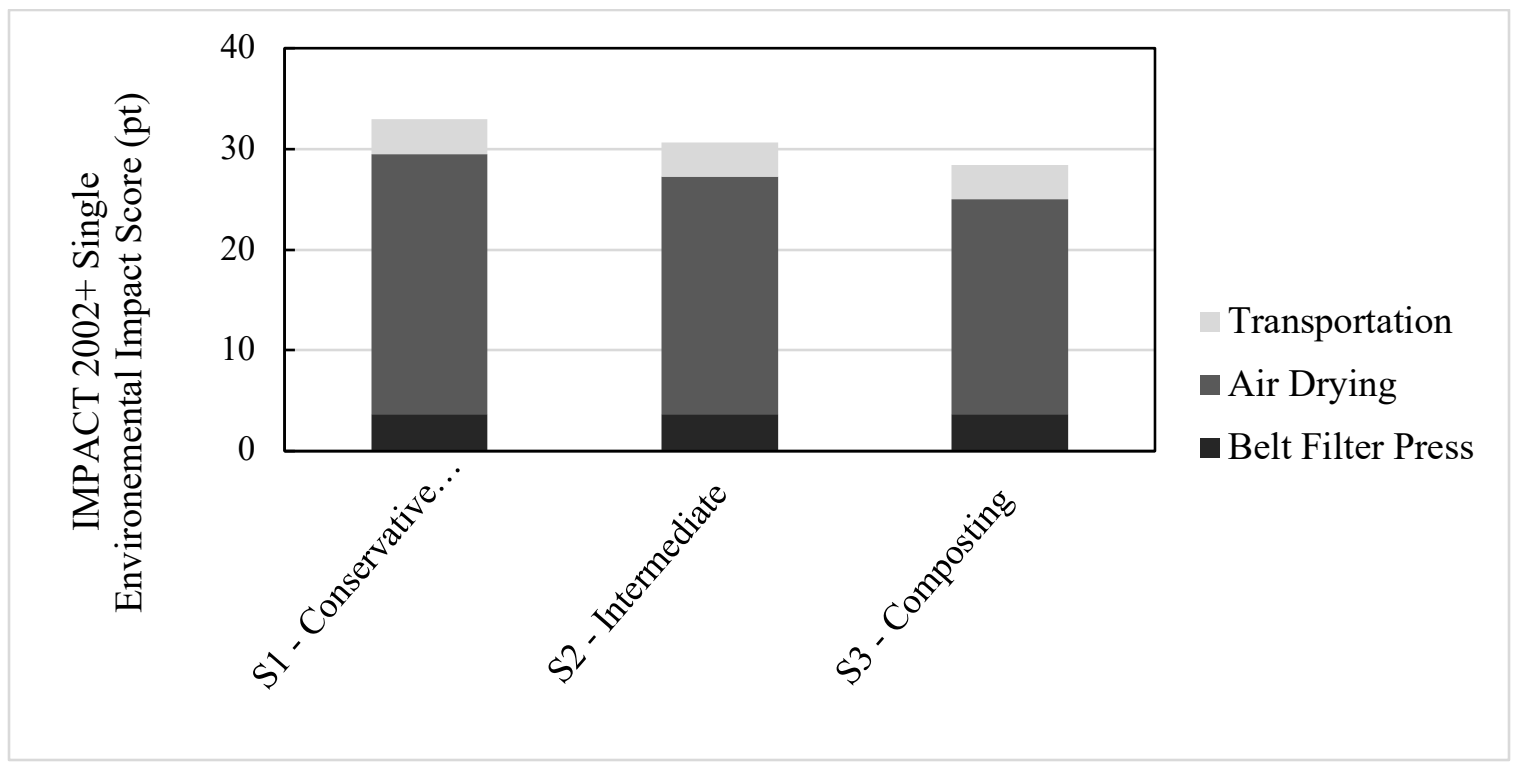

Figure 3.4. Air drying sensitivity analysis results. Shade of gray represent the unit processes within air drying

\subsubsection{Lagoon Storage plus Air Drying Results}

The total environmental impacts single score for the LCLT technology of lagoon storage plus air drying is $39.3 \mathrm{pt}$, which was the third highest score. $76 \%$ of those environmental impacts come from the climate change category as illustrated in Figure 3.1. The sources for the impacts from climate change and the other damage categories are presented in Figure 3.5 as produced by lagoon storage's unit processes. The air drying process, which includes turning windrows of biosolids periodically for ten weeks, contributes the most to the climate change and resources impacts. In contrast, transportation contributes the most to the human health and ecosystem quality impacts. 


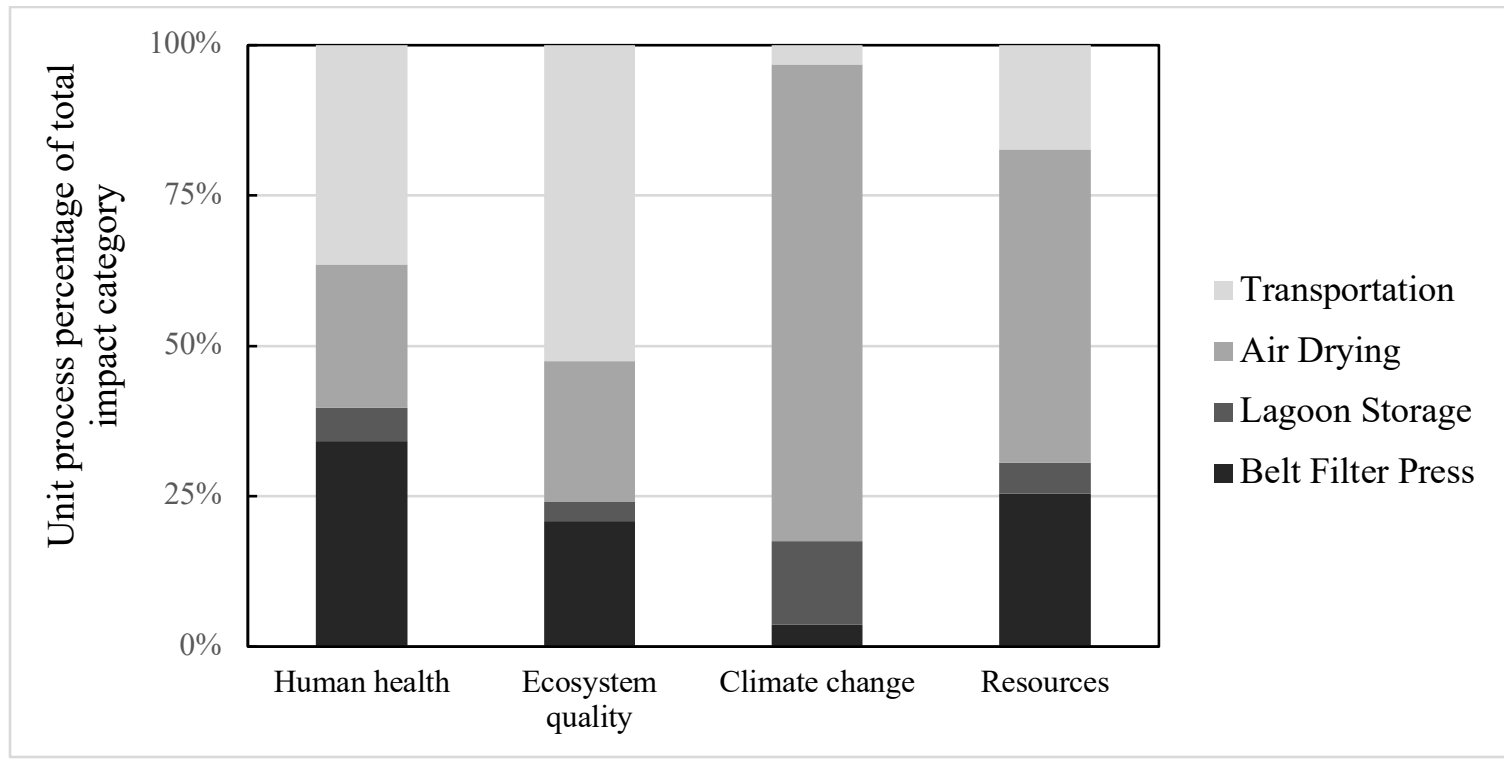

Figure 3.5. Environmental impacts of lagoon storage unit processes. Shades of gray represent the unit processes of lagoon storage

Lagoon storage's environmental impacts were further broken down to demonstrate the source of impacts in Figure 3.5, as shown in Figure 3.6. Biogenic emissions account for the majority of impacts followed distantly by 'Utilities/Fuel', i.e., the electricity for dewatering and diesel for moving and turning biosolids.

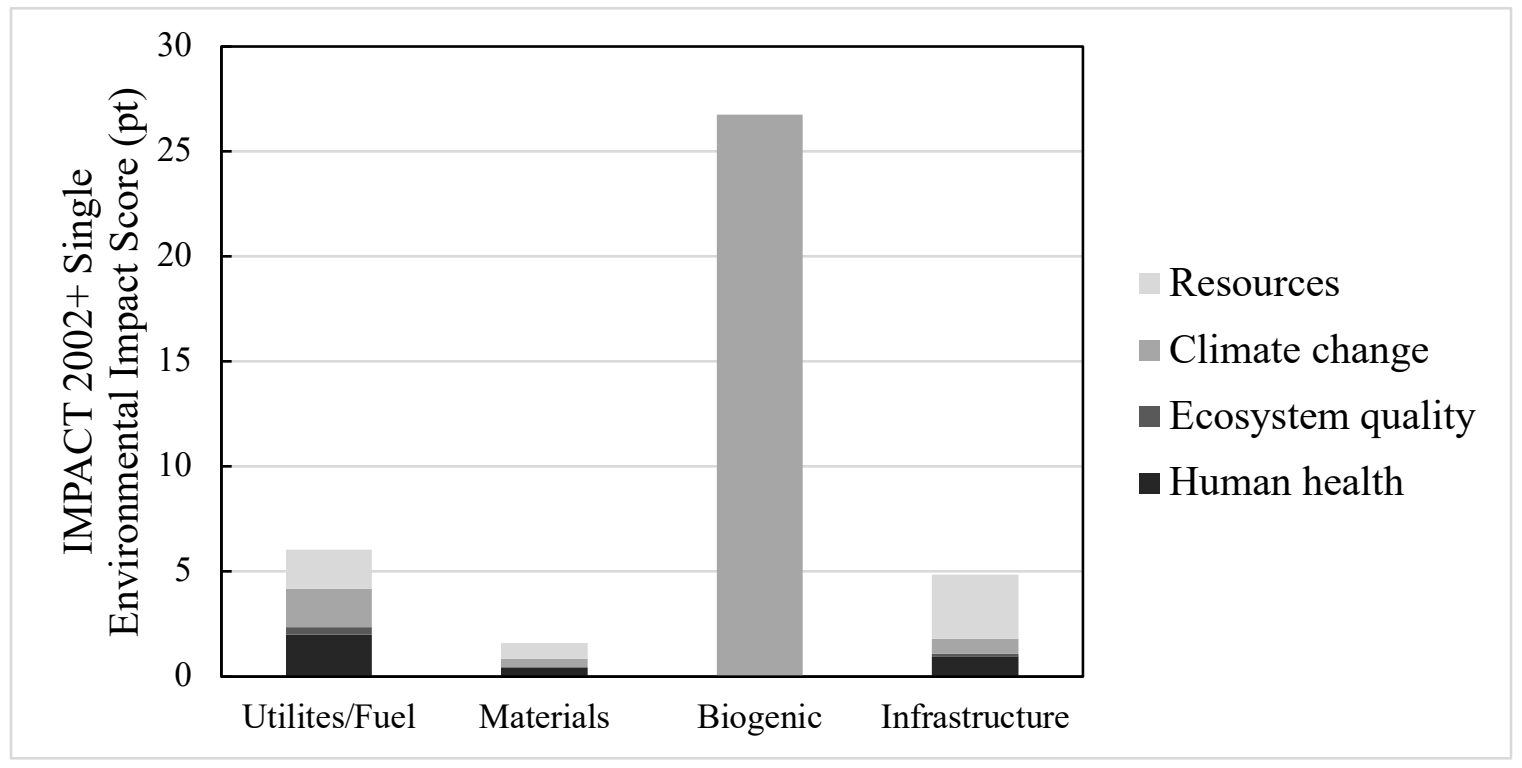

Figure 3.6. Environmental impacts of lagoon storage separated by utilities/fuel, materials, biogenic, and infrastructure sources. The different shades of gray represent the four damage categories 


\subsubsection{Air Drying Unit Sensitivity Analysis}

The same sensitivity that was conducted for air drying alone, looking at the impact of the gas production assumption, was done for the air drying unit process in the coupled lagoon storage plus air drying case. The conservative, baseline scenario scored an environmental impact of $39.3 \mathrm{pt}$ while the composting-like scenario scored 34.8. A small change in the composition of methane and nitrous oxide emissions results in a five-point difference in the overall environmental impact score. As discussed above, a better understanding of the biogenic gas emissions that occur during these processes would be beneficial for understanding the environmental impacts.

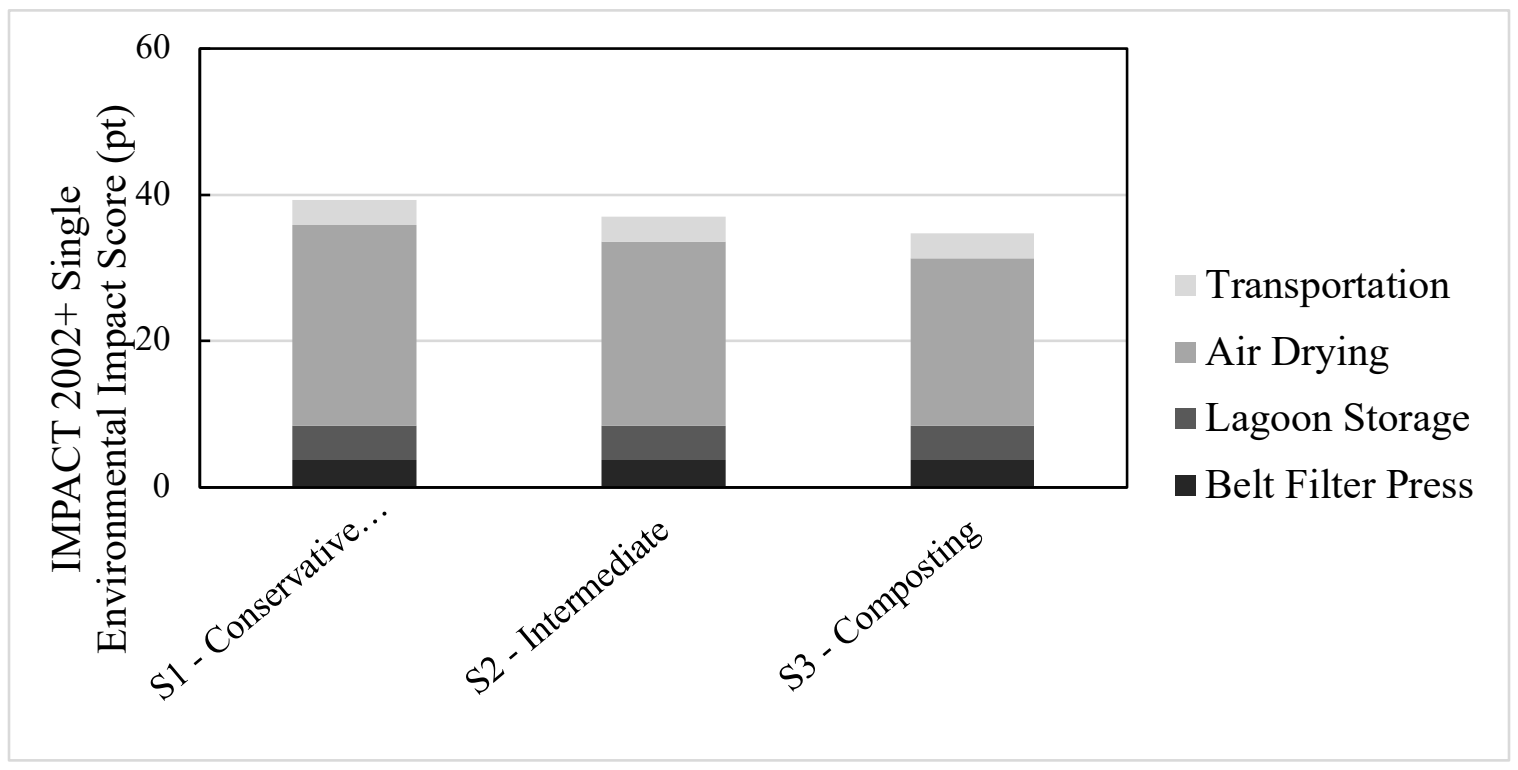

Figure 3.7. Lagoon storage sensitivity analysis. Shades of gray represent unit processes in lagoon storage

\subsubsection{Composting Results}

The total environmental impacts single score for PFRP technology of composting is 70.3 $\mathrm{pt}$, which was the highest score of the five processes. Roughly $65 \%$ of the environmental impacts for composting come from the climate change category as shown in Figure 3.1. Figure 3.8 displays the score for each of the damage categories as produced by composting's unit processes. The composting process, which includes placing biosolids and amendments in windrows, turning them once a week, and then screening of the final product, contributes the most to climate change, human health and resources. The biogenic emissions of carbon dioxide and methane and the use of sawdust account for $92 \%$ of the climate change category impact score. In comparison, transportation contributes the most to ecosystem quality. 


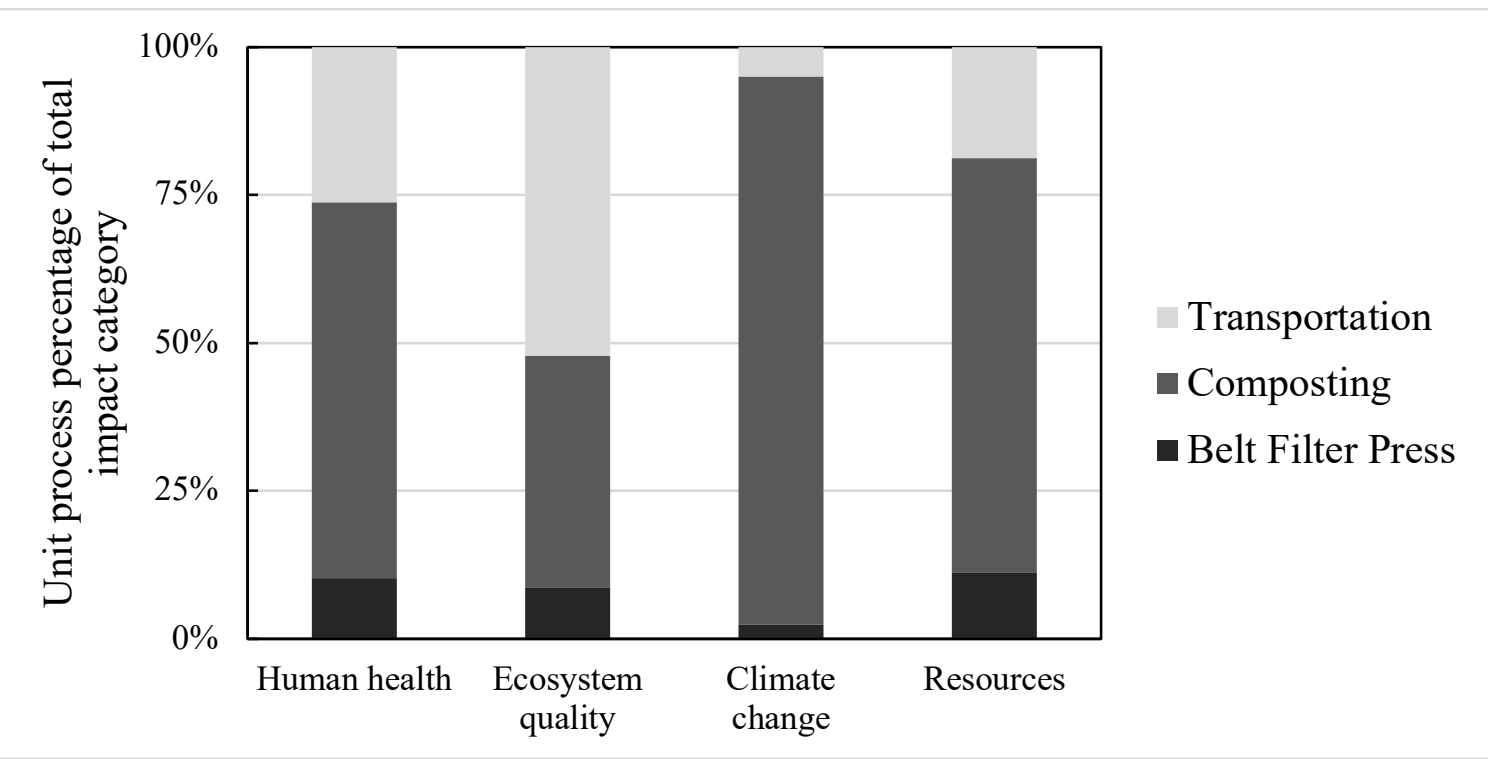

Figure 3.8. Environmental impacts of composting unit processes. Shades of gray represent the unit processes of composting

Composting's environmental impacts shown in Figure 3.8 were further broken down to show the sources of those impacts as illustrated in Figure 3.9. Biogenic emissions accounts for the majority of impacts followed by materials. The materials in this case represents the sawdust and woodchips used as amendments.

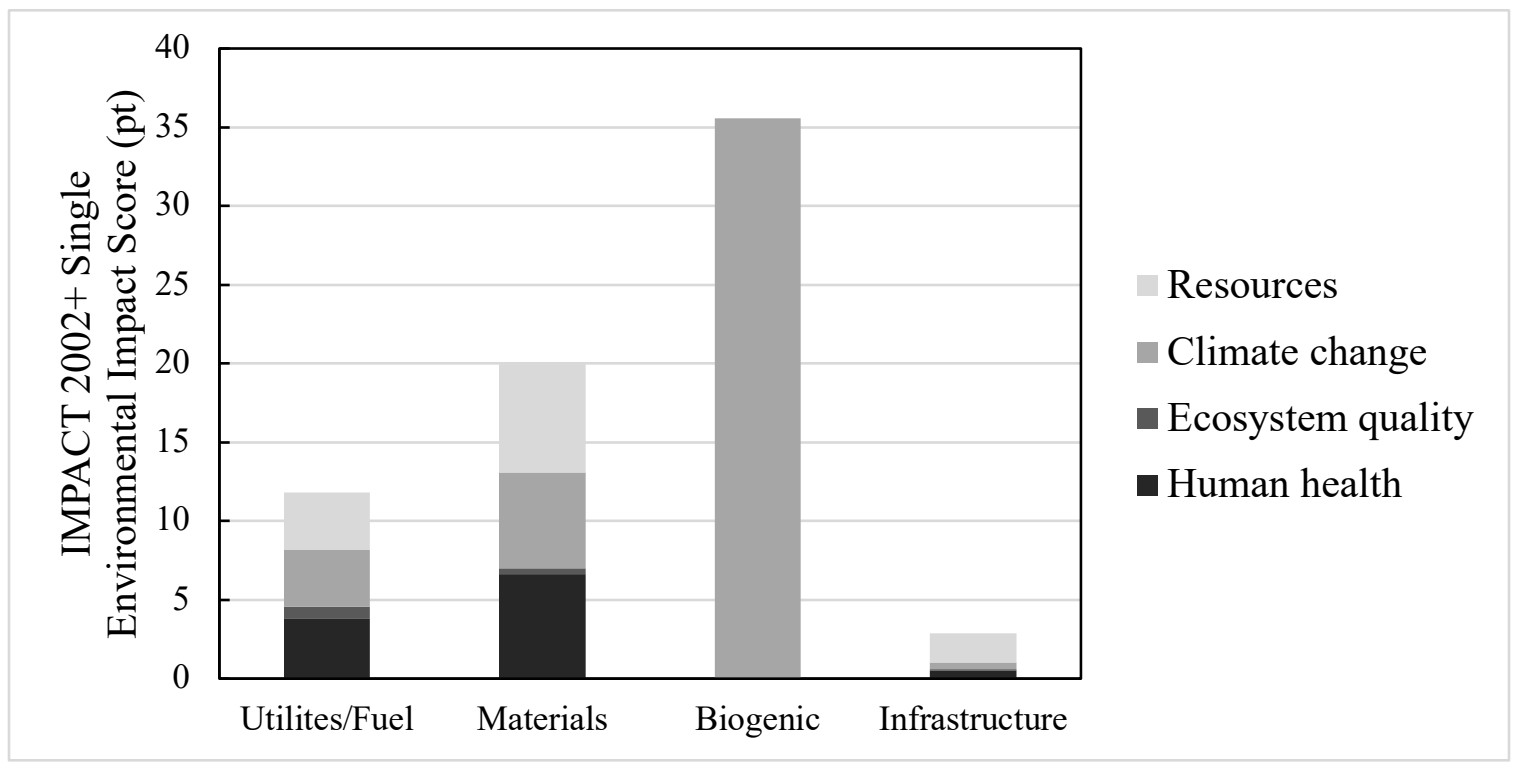

Figure 3.9. Environmental impacts of composting separated by utilities/fuel, materials, biogenic, and infrastructure sources. Shades of gray represent the four damage categories. 


\subsubsection{Direct Heat Drying Results}

The total environmental impacts single score for the PFRP technology of direct heat drying is 50.3 pt., which was the second highest score of the five processes. $40 \%$ of the environmental impacts come from the resources category as shown in Figure 3.1. To examine that result further, the score for each of the damage categories influenced by the direct heat drying unit processes is presented in Figure 3.10. The direct heat drying process itself, which includes burning natural gas to product hot gases to dry the biosolids, contributes the most to all four damage categories. Transportation was a smaller contributor to all of the damage categories due to the very high percentage of solids in the end product, i.e., less water in the biosolids means less weight to transport.

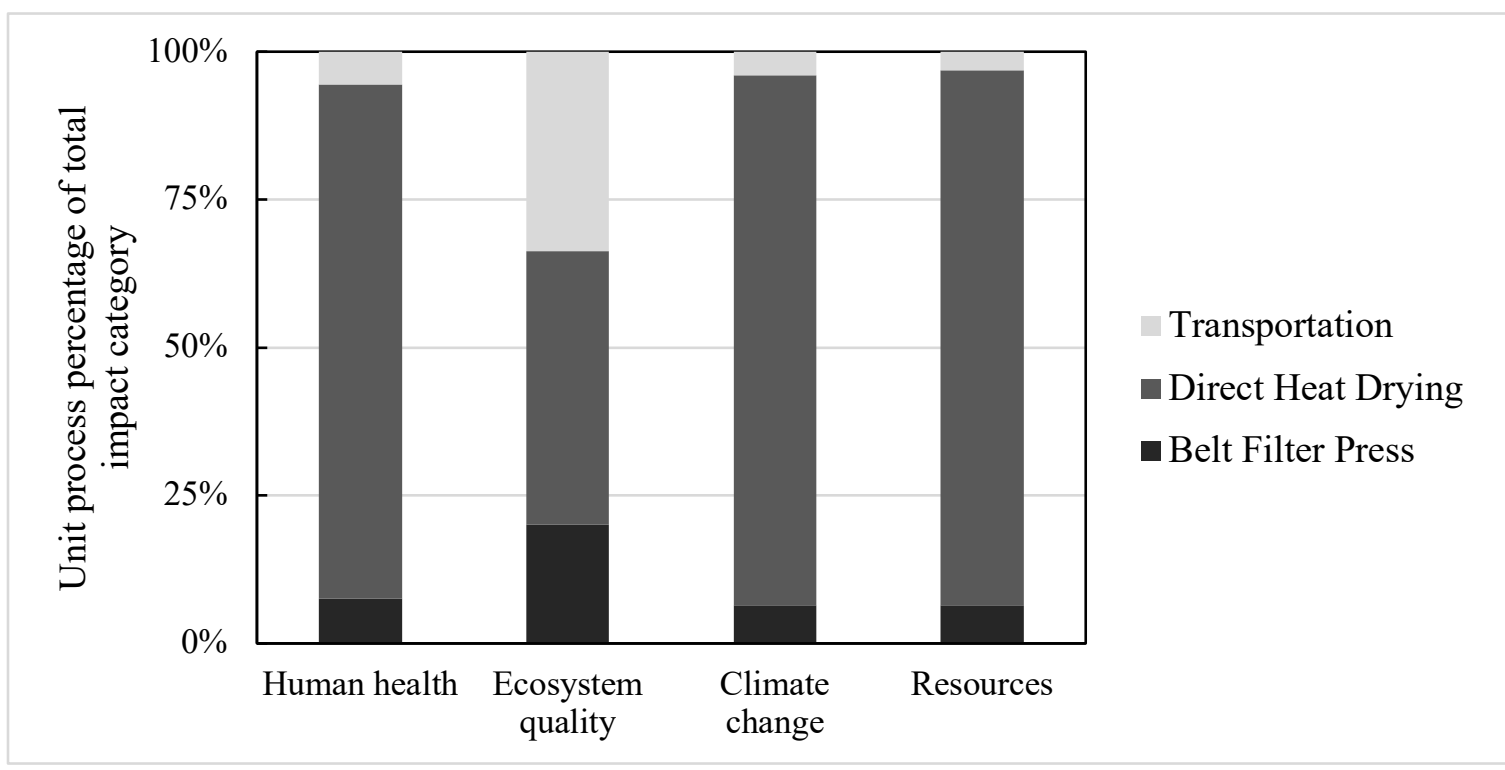

Figure 3.10. Environmental impacts of direct heat drying unit processes. Shades of gray represent the unit processes of direct heat drying

Direct heat drying's environmental impacts (Figure 3.10) were broken down further to evaluate the sources of those impacts, as shown in Figure 3.11. In this case, the 'Utilities/Fuel' sources clearly account for the majority of the environmental impacts, which represents the electricity used in mechanical dewatering, the natural gas used in the rotary dryer, and the fuel used in transportation. The small amount of materials contributing to the environmental impacts is due to the polymer used in mechanical dewatering. A key assumption made in this analysis was that no volatile solids were destroyed during the direct heat drying process. Therefore, it was also assumed that no biogenic emissions of carbon dioxide, methane, or nitrous oxide occurred. If there are biogenic emissions, the result would be an increase in environmental impacts in the climate change damage category. This assumption should be verified in future research. 


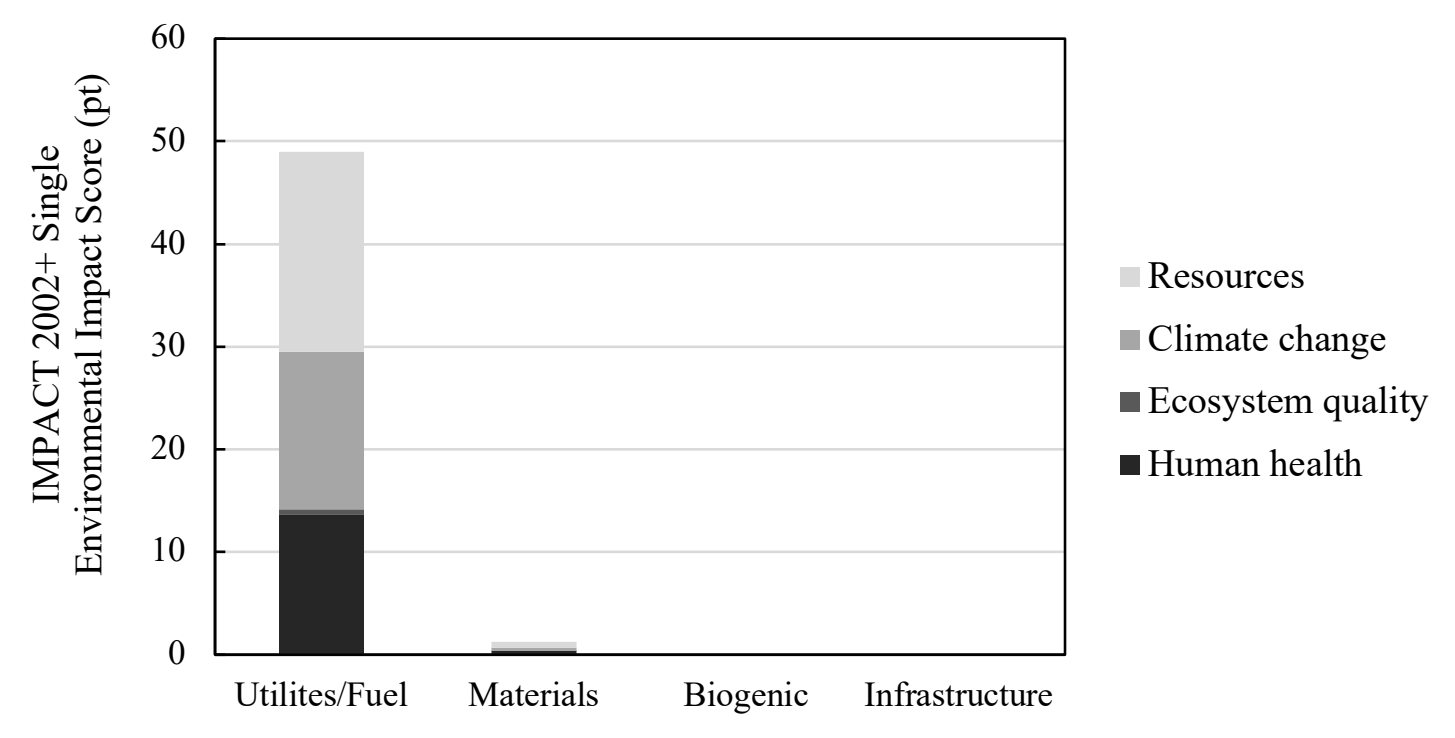

Figure 3.11. Environmental impacts of direct heat drying separated by utilities/fuel, materials, biogenic, and infrastructure sources. Shades of gray represent the four damage categories

\subsubsection{TPAD Results}

The total environmental impacts single score for the conventional TPAD technology is $19.5 \mathrm{pt}$, which was the lowest of the five processes evaluated. Of the environmental impacts, 37\% come from the climate change category, 30\% from the human heath category, and $28 \%$ from the resources category (Figure 3.1). The scores for each of the damage categories produced by the TPAD unit processes are displayed in Figure 3.12. The TPAD unit process, which includes a thermophilic digester heated by biogas and mixed and pumped by electricity, contributes the most to the climate change damage categories, whereas transportation contributes the most to the other three categories. The greater contribution of transportation is due to the fact that the TPAD biosolids are only dewatered to $22 \%$ solids, whereas the other processes are dewatered to at least $60 \%$ solids. Thus, there is a large amount of water to transport in the biosolids. 


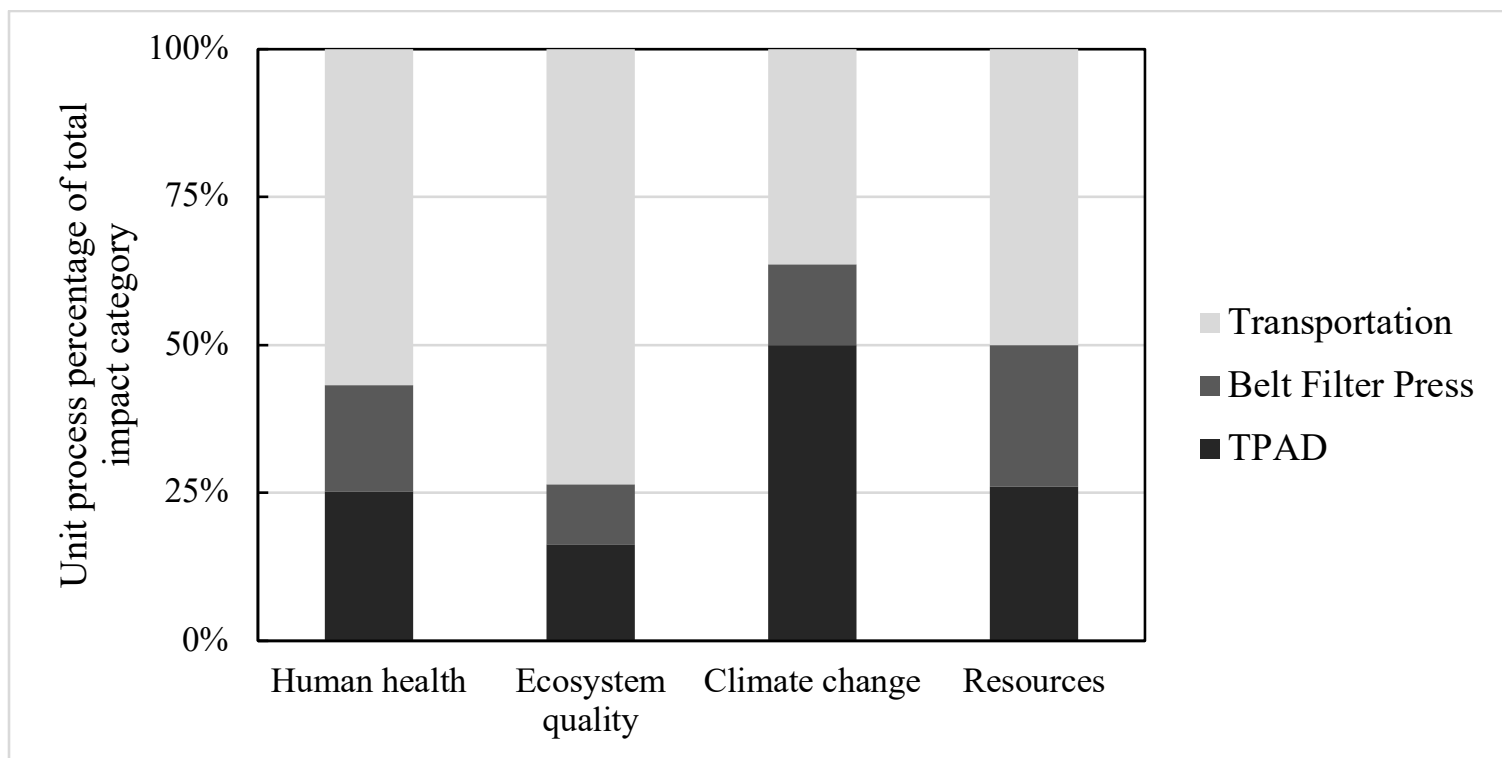

Figure 3.12. Environmental impacts of TPAD unit processes. Shades of gray represent the unit processes of TPAD

TPAD's environmental impacts presented in Figure 3.12 were analyzed further by examining the sources of the impacts as shown in Figure 3.13. The 'Utilities/Fuel' account for the majority of the environmental impacts. This includes the electricity used in mechanical dewatering and in TPAD for mixing and pumping, and the fuel used in transportation. The small amount of environmental impacts associated with materials is a result of the polymer used in mechanical dewatering.

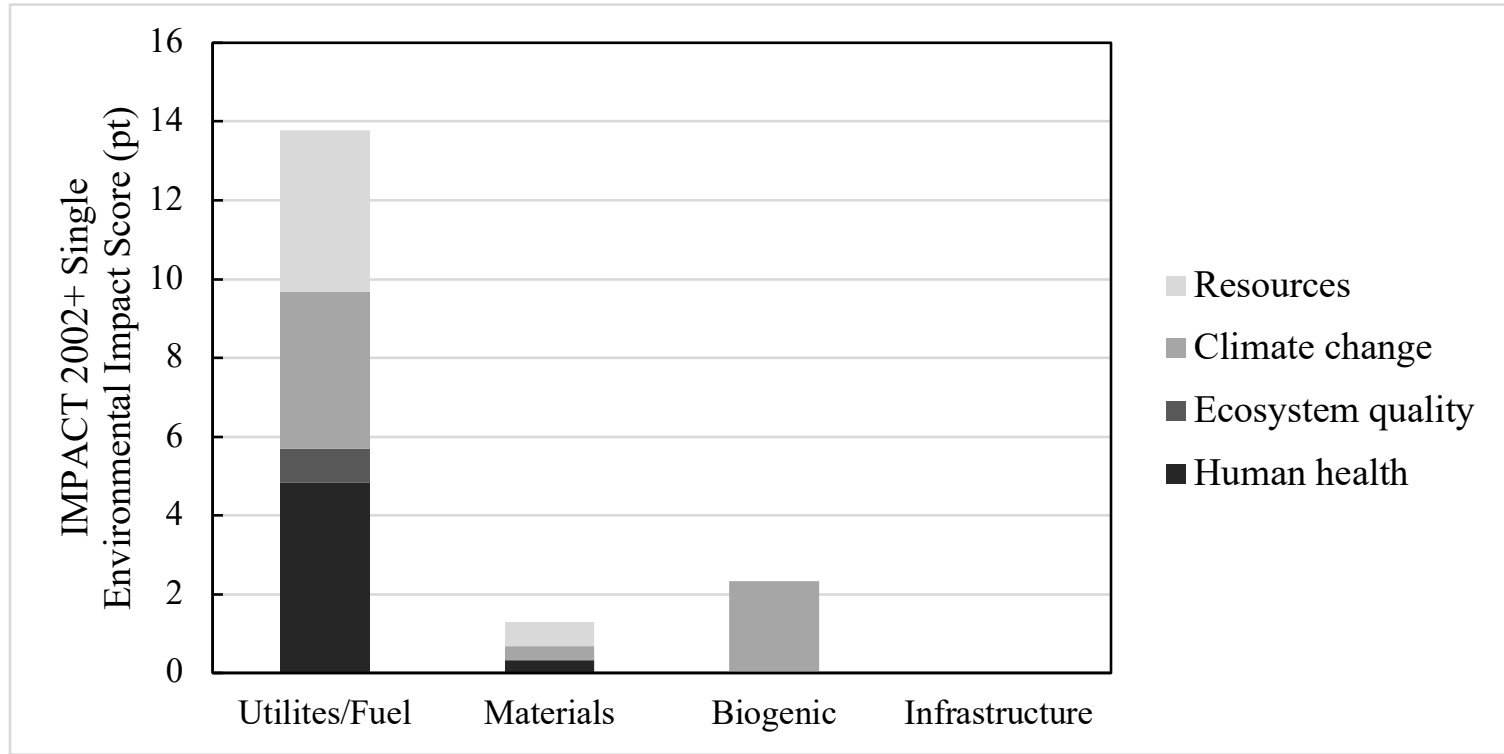

Figure 3.13. Environmental impacts of TPAD separated by utilities/fuel, materials, biogenic, and infrastructure sources. Shades of gray represent the four damage categories 


\subsubsection{Transportation Sensitivity Analysis}

The distances that biosolids have to be transported before they can be land-applied varies greatly among WRRFs, and transportation has substantial environmental impacts. Therefore, a sensitivity analysis was conducted to evaluate the impact of biosolids transportation distances on LCA outcomes.

Four transportation scenarios were considered. Scenario 1 is representative of rural WRRF in which biosolids can be land-applied within $~ 10$ miles of the utility, as is the case in Houghton, MI. In Scenario 2, biosolids land application sites are $\sim 50$ miles from treatment utilities. This situation may apply to utilities located in smaller cities or suburban locations in states where Class A biosolids application is allowed. Scenarios 3 and 4 are representative of WRRFs that have to transport their biosolids out of states such as California. In LCA studies, units for transportation are incorporated as the product of a mass and a distance, such as tonne-kilometer (tkm). Therefore, both the weight of the final Class A product and the distance affects the environmental impacts. The cumulative environmental impacts for the four biosolids transportation distances are summarized for the five treatment processes in Figure 3.14. It is important to note that one-way transportation distances are given in Figure 3.14; however, the environmental impacts of transportation were based on round-trip travel because it is assumed that the empty trucks returned to the WRRFs, and thus both directions of travel contributed to the environmental impacts of the treatment process.

Direct heat drying produces a final biosolids product with a very high percentage of solids. The total mass of biosolids that must be transported for heat dried biosolids is, as a result relatively small. Consequently, varying the transportation distance also has relatively little effect on the environmental impacts of heat drying. On the other hand, the biosolids produced by TPAD contain a low percentage of total solids. This means that the total mass of biosolids that must be transported is high. When a large mass of biosolids must be transported, changing the transportation distance has a substantial effect on the overall environmental impacts of biosolids treatment. Interestingly, whereas TPAD has the lowest overall environmental impacts when a one-way travel distance of 10 miles is assumed, the environmental impacts of TPAD exceed those of air drying in scenario 4 (200 mile one-way travel distance) because of the wetter nature of the biosolids and greater mass and volume of biosolids that have to be hauled. Transportation also has a substantial effect on the environmental impacts of composted biosolids except that in this case, the additional mass and volume of biosolids that must be transported is not due to moisture. Instead it is due to the additions of sawdust and woodchips to biosolids during the composting process. It is important to note that these calculations were based on the assumption that the volume of sawdust will be reduced by $40 \%$ and the woodchips are screened out with a 70\% efficiency. However, the amounts of amendments that actually remain in the final biosolids product will influence how much transportation distances affect the environmental impacts of composting. 


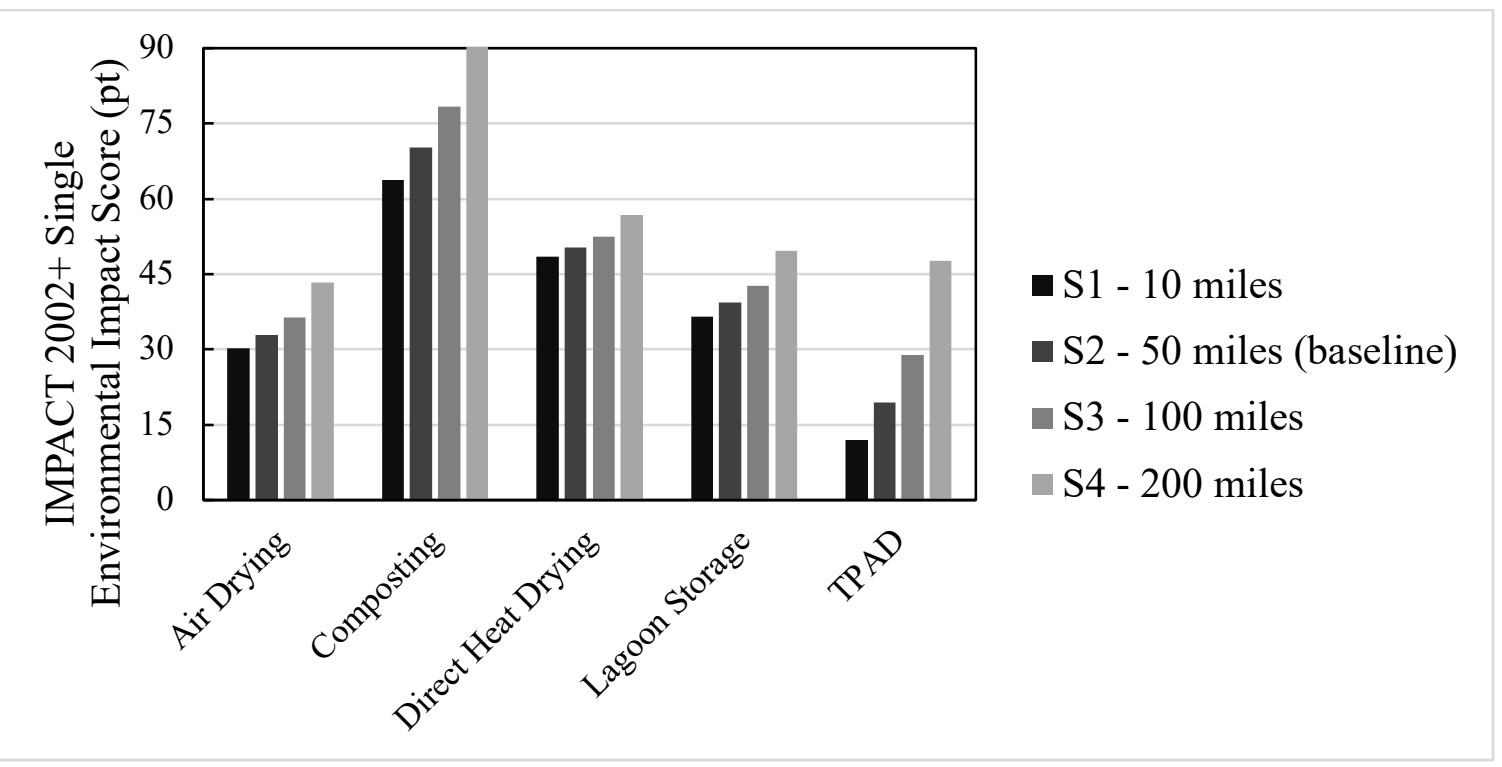

Figure 3.14. Transportation sensitivity analysis

\subsubsection{Greenhouse Gas Emissions Comparison}

There are many factors that affect the composition of the biogenic emissions from the production of Class A biosolids including oxygen availability, moisture content, the activity of methanotrophic bacteria, and the $\mathrm{C} / \mathrm{N}$ ratio of the biosolids. Increasing oxygen levels during treatment leads to greater aerobic and less anaerobic microbiological activity and thus is associated with lower methane emissions and greater carbon dioxide emissions. Methanotrophic bacteria oxidize methane to carbon dioxide using oxygen as an electron acceptor, and their activity is also stimulated by increased oxygen availability (SYLVIS 2009). In particular, adding a bulking agent to composted biosolids, and turning composting and air drying windrows aerate the windrows. Composting and air drying methane emissions are also dependent on the level of moisture present in the windrows because as the windrows dry, a greater percentage of the pore spaces are filled with air rather than water (SYLVIS 2009). Yamulki (2006) showed that as the C/N ratio in the manure increased, less methane and nitrous oxide was produced.

The estimated composition and quantity of biogenic emissions from Class A biosolids treatment via air drying, composting, and lagoon storage are summarized in Figure 3.15. Air drying produces more nitrous oxide compared to composting presumably because biosolids treated via air drying are not amended with a carbon feedstock and thus have a lower $\mathrm{C} / \mathrm{N}$ ratio compared to biosolids that are amended with sawdust and composted. Methane is present in air drying and composting because the two processes will never be completely aerobic (Metcalf and Eddy 2014). Lagoon storage's emissions are dominated by the carbon dioxide and methane produced during the air drying stage. This explains why the total emissions and their make-up are so similar for air drying and lagoon storage. It should be noted that the emissions data used to estimate lagoon storage's emissions were based on biosolids stockpiles that were $20 \mathrm{ft}$ to $30 \mathrm{ft}$ deep (Majumder, 
Livesley et al. 2014). In contrast, the depth of the lagoons in this report is 5 feet. Further, in the study conducted by Majumder (2014), the biosolids were treated by anaerobic lagoons, aerobic lagoons, and then air dried before being put into stockpiles. Finally, the percent solids in the stockpiles are twice as great as the percent solids in this report's lagoon storage. Even though the treatment process, depth, and percent solids are different, this paper comes the closest to fitting this study's lagoon storage operating assumptions.

In general, there was relatively little information in the literature on biogenic gas emissions from biosolids drying air drying and especially, lagoon storage. To improve the accuracy of LCA analyses, more data on these emissions profiles are needed.

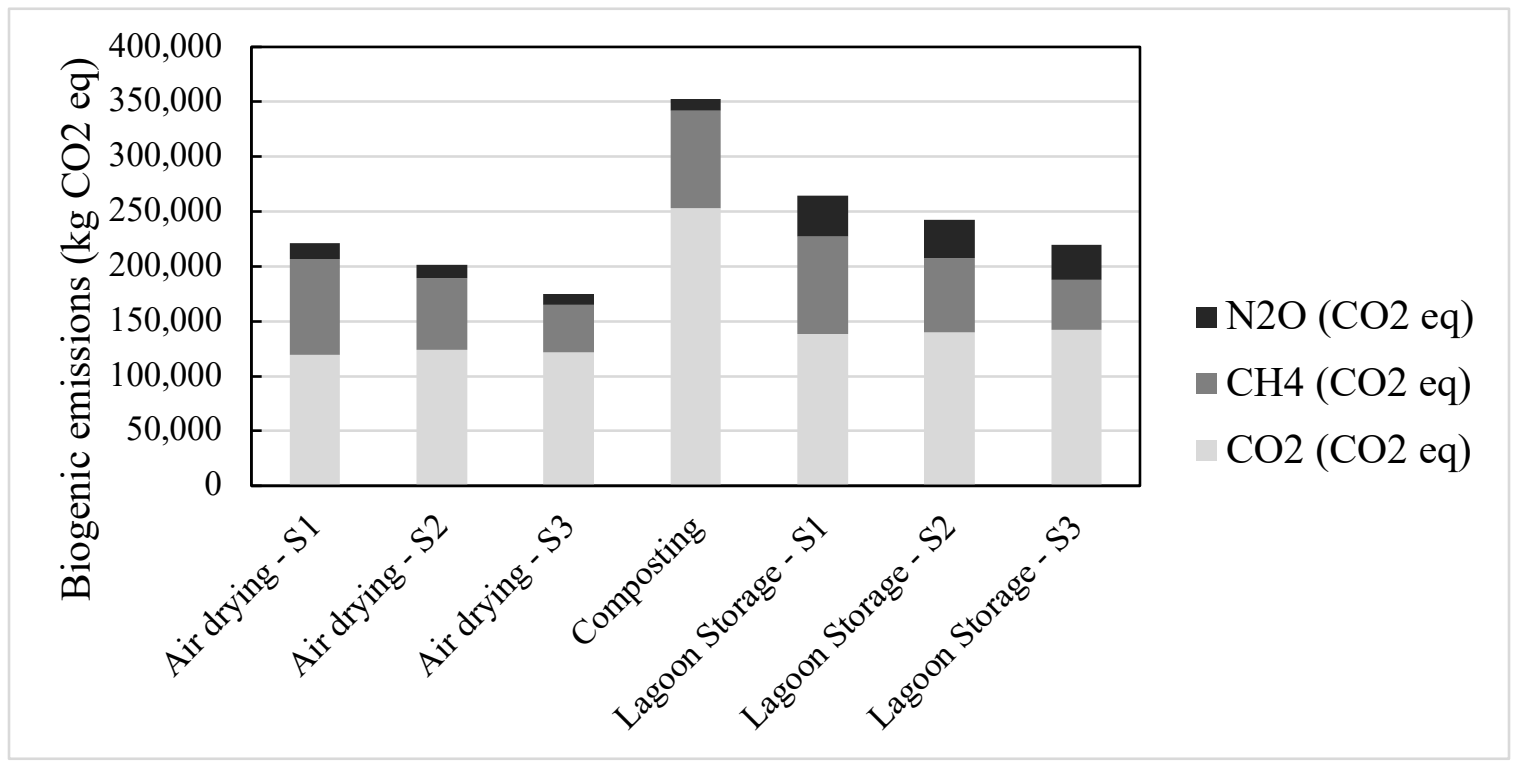

Figure 3.15. Biogenic emissions for air drying, lagoon storage, and composting. S1, S2, and $\mathrm{S} 3$ refer to the air drying sensitivity analysis scenarios (see Table 2.3)

\subsection{Economic}

The capital and O\&M costs of each Class A biosolids treatment process were analyzed separately. As expected, the two LCLT processes, lagoon storage and air drying, had very low capital costs $(<\$ 1$ million), relative to TPAD and direct heat drying, which had total capital costs of $\$ 16.5$ and $\$ 11.7$ million, respectively (Figure 3.16). This makes sense because other than a windrow turner, no mechanized equipment has to be purchased for lagoon storage or air drying. Implementation of lagoon storage requires construction of four lagoons and an air drying pad. Therefore, the capital costs for lagoon storage exceed those of air drying, for which lagoons are not needed. The capital costs associated with lagoon storage include the acquisition and emplacement of a six-inch clay liner plus a 40 mil. HDPE liner. Air drying capital costs reflect the construction of an asphalt pad and the purchase of a windrow turner. In contrast to the LCLT treatment processes, tanks or reaction vessels, heat sources, mixers, and controls are required for both TPAD and direct 
heat drying, which drive up the capital costs associated with these processes. In particular, the capital cost of a new rotary dryer is millions of dollars. In some cases, it may be possible for WRRFs to retrofit existing tanks for use in TPAD, which could decrease the capital costs. A California WRRF was able to retrofit an existing digester for $\$ 2.5$ million (USEPA 2006). In contrast, all new construction of the same TPAD system would have cost $\$ 16.5$ million. Composting is a conventional technology but had a low capital cost because it was assumed that it would be accomplished using windrows. Windrow composting is a simple, less highly controlled technology compared to invessel composting. In-vessel composting requires $\$ 30,000$ to $\$ 75,000$ per dry ton in capital costs due to the need to purchase reaction vessels, controls, and other equipment (EPA 2002). Although in-vessel requires more upfront costs, windrow composting requires more O\&M costs for labor, fuel, and materials.

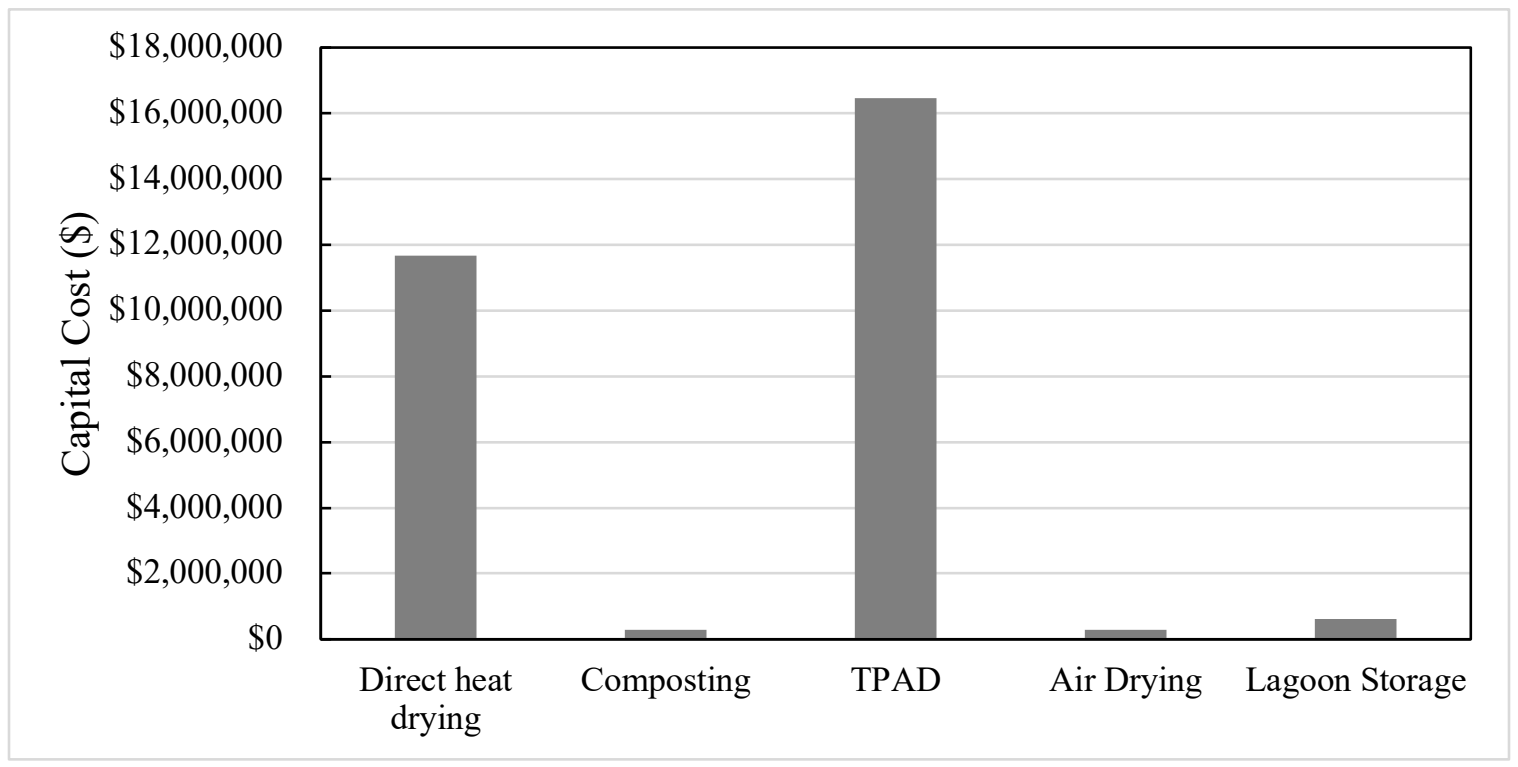

Figure 3.16. Capital cost for all processes 


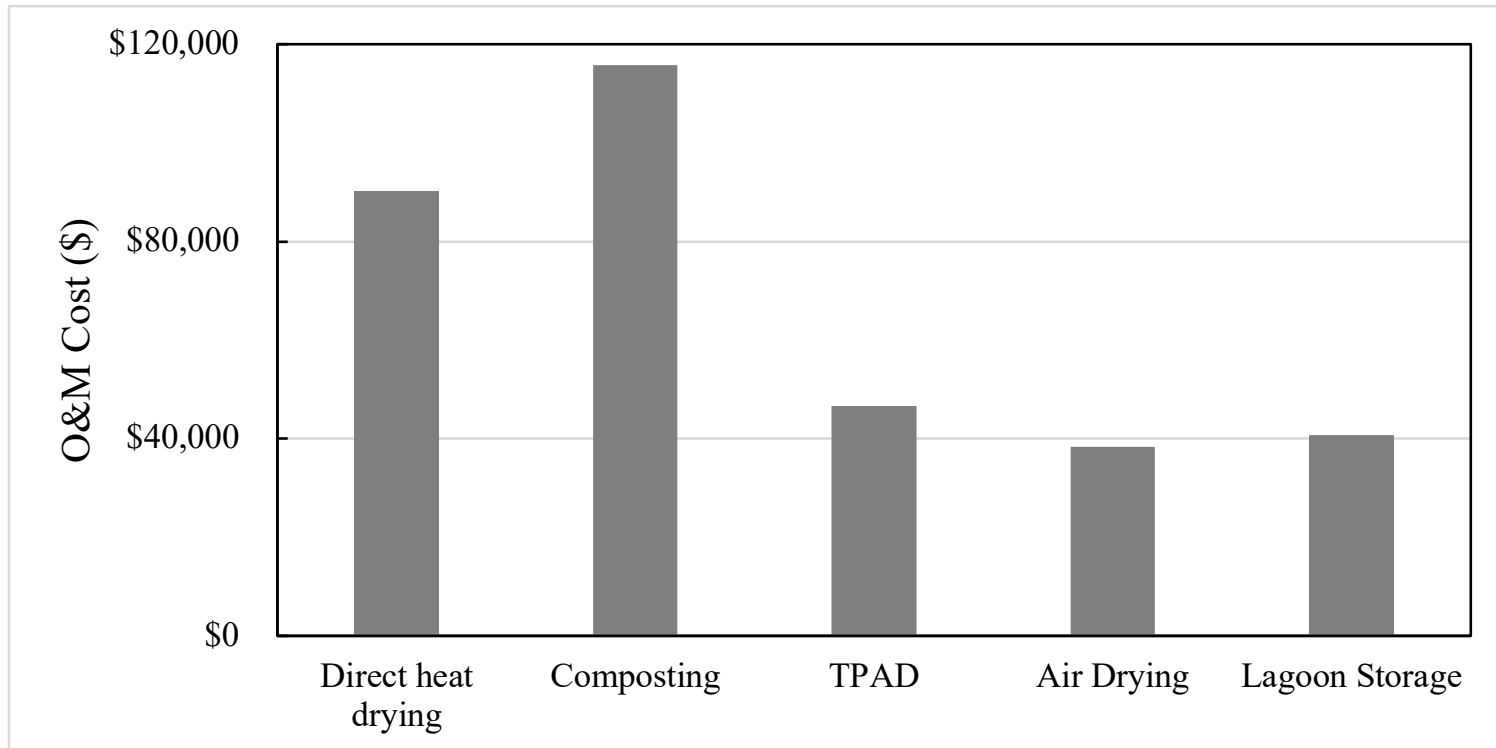

Figure 3.17. First year of operations and maintenance (O\&M) cost for all processes. A one-way biosolids transportation distance of 50 miles was assumed

The total O\&M costs are fairly similar for conventional and LCLT processes (Figure 3.17). In general, conventional technologies consume large quantities of natural gas and electricity, whereas the LCLT processes and composting require large quantities of fuel, labor, and materials, as shown in Figure 3.18. As noted above, the environmental impacts associated with biosolids produced via composting and TPAD are substantially impacted by transportation because the mass and volume of biosolids produced is larger than for the other technologies. Likewise, the O\&M costs associated with composting and TPAD are heavily influenced by transportation costs (data not shown).

Direct heat drying is an energy intensive, conventional technology that requires large inputs of natural gas. The O\&M costs associated with transportation of heat dried biosolids are low because the final product contains $95 \%$ total solids, and thus relatively little material must be transported, as discussed above. TPAD also requires electricity to power mixers and pumps. In this study, it was assumed that the biogas produced via the TPAD process is sufficient to heat both digester phases. If this assumption is not correct, the O\&M costs will be significantly higher. TPAD transportation costs are similar to those associated with composting because TPAD-treated biosolids contain only $22 \%$ total solids, and thus the total amount of material that must be transported is large.

Biosolids composting operations require both carbon and structural amendments, which not only have to purchased, transported, stored, and managed, but also increase the total amount of biosolids that has to be transported to land application sites. As a result, the O\&M costs for composting are higher than for lagoon storage and air drying. 


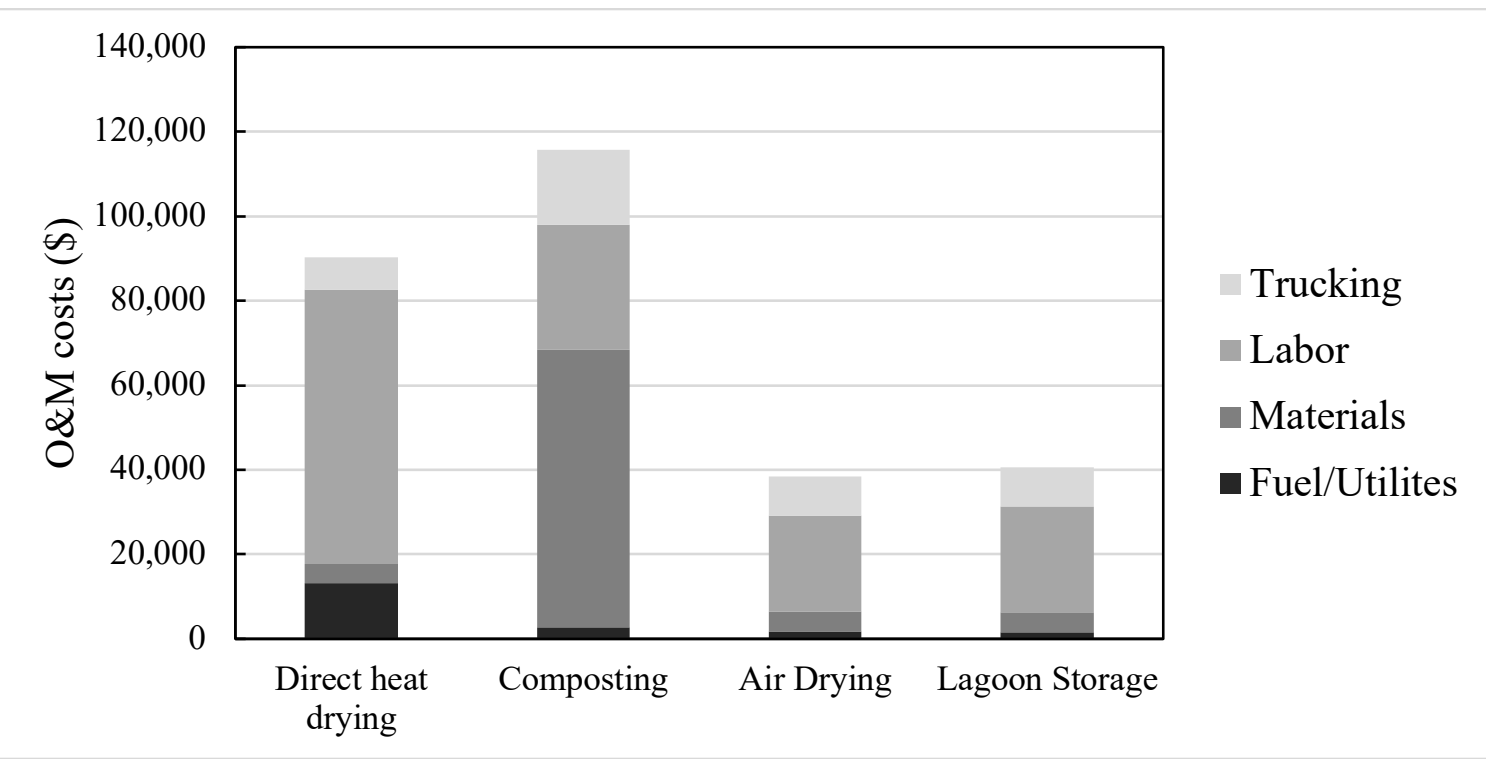

Figure 3.18. Contributions of transportation, labor, materials, and fuel and other utilities to the O\&M costs associated with direct heat drying, composting, air drying, and lagoon storage. TPAD is not included because the O\&M costs could not be separated into the different categories.

The total economic impacts were equally distributed between capital costs and O\&M costs, which means the capital and O\&M costs were each normalized on a 0 to 5 scale, according to:

$$
\operatorname{Score}_{i}=\frac{O \& M_{i}}{O \& M_{\text {high }}} * 5
$$

where Score $_{\mathrm{i}}=$ normalized score for ' $\mathrm{i}$ ' process, $\mathrm{O} \& \mathrm{Mi}=\mathrm{O} \& \mathrm{M}$ cost for ' $\mathrm{i}$ ' process, and $O \& M_{\text {high }}=$ the highest O\&M cost. The normalized scores were summed to calculate the total economic impact. By normalizing the O\&M and capital costs in this this way, differences in the O\&M costs, while orders of magnitude smaller than the capital costs, are reflected in the total economic impacts. Another way to approach the ranking of the economic impacts of the biosolids treatment processes is to perform a life cycle cost analysis that accounts for the capital costs and the total O\&M costs over the lifetime of the process. The life cycle costs could then be normalized on a scale of 0 to 10 . The economic rankings were determined using these two approaches are listed for the conventional and LCLT biosolids treatment processes in Table 3.1. Interestingly, the total economic impacts of the biosolids treatment processes calculated using both methods increased in the order of air drying, lagoon storage and composting. However, TPAD and direct heat drying had the fourth and fifth, respectively, greatest total economic impacts when calculated by normalizing the capital and O\&M costs. In contrast, when using a life cycle cost analysis, direct heat drying had a lower total economic impact compared to TPAD. These results highlight the importance of explicitly identifying the methods that are used to compare the impacts of different biosolids treatment processes. 


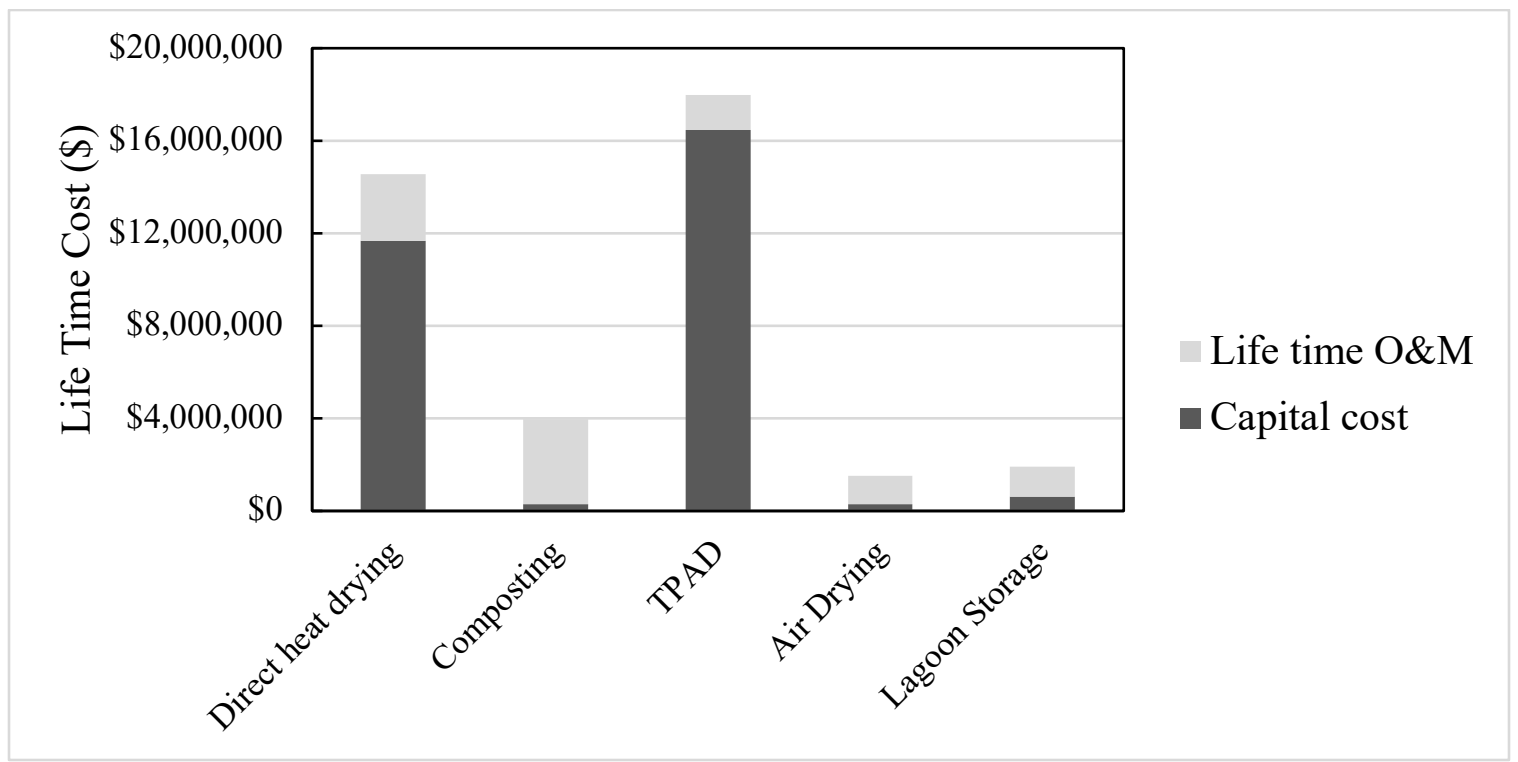

Figure 3.19. Life time cost for each process. Life time O\&M costs accounts for $2 \%$ inflation and a life time of 25 years.

Table 3.1. Overall economic impacts of biosolids treatment processes based on normalized capital and O\&M costs and life cycle cost analysis

\begin{tabular}{|l|c|c|c|c|}
\hline $\begin{array}{l}\text { Class A } \\
\text { biosolids } \\
\text { treatment } \\
\text { process }\end{array}$ & \multicolumn{2}{|c|}{$\begin{array}{c}\text { Economic ranking based on equally weighed, } \\
\text { normalized capital and O\&M costs }\end{array}$} & $\begin{array}{c}\text { Life cycle cost } \\
\text { analysis } \\
\text { based }^{\mathbf{a}}\end{array}$ \\
\cline { 2 - 5 } & $\begin{array}{c}\text { Normalized } \\
\text { capital costs }\end{array}$ & $\begin{array}{c}\text { Normalized } \\
\text { O\&M costs }\end{array}$ & $\begin{array}{c}\text { Total } \\
\text { normalized } \\
\text { costs }\end{array}$ & $\begin{array}{c}\text { Sum of } \\
\text { amortized } \\
\text { capital and } \\
\text { O\&M costs }\end{array}$ \\
\hline Air Drying & 0.09 & 1.66 & 1.74 & 0.84 \\
\hline $\begin{array}{l}\text { Lagoon } \\
\text { Storage }\end{array}$ & 0.19 & 1.76 & 1.94 & 1.07 \\
\hline Composting & 0.09 & 5.00 & 5.09 & 2.22 \\
\hline $\begin{array}{l}\text { Direct Heat } \\
\text { Drying }\end{array}$ & 3.54 & 3.90 & 7.44 & 8.11 \\
\hline TPAD & 5.00 & 2.01 & 7.01 & 10.00 \\
\hline
\end{tabular}

${ }^{\mathrm{a} A s s u m e s}$ a process life span of 25 years and an inflation rate of $2 \%$

\subsection{Social}

In general, the public has a negative attitude about the land application of biosolids due to their objections to the aesthetics of the material being land-applied and concern about human health impacts. One study surveyed the residents in two cities in the southeastern United States to assess the general public's knowledge and attitudes towards land application of biosolids (Robinson, Robinson et al. 2012). The study found that $50 \%$ of 
the 311 residents could not correctly answer a true or false type of question designed to test their basic biosolids knowledge. Specifically, more than half of the half of the individuals who were surveyed answered "false" in response to the following question: The EPA currently regulates the levels of disease-causing bacteria in biosolids (Robinson, Robinson et al. 2012). Through their answers, the residents of these cities also indicated that biosolids should not be applied to gardens, yards, public areas, food crops, and pastures. The majority of the individuals who were surveyed think that the risk to public health and the environment outweighs the benefits of land-applied biosolids. Another key outcome of the survey is the finding that the residents believe they are not adequately informed about biosolids and are not satisfied with the decision-making process (Robinson, Robinson et al. 2012). Thus, getting the public to understand and accept biosolids land application may be key to the success of a biosolids reuse program. Odor is the one of the biggest sources of complaints associated with the land application of biosolids (Lang, Forste et al. 2011). Others include truck traffic/transportation, the physical appearance of the WRRF facility, and dust. In addition, members of the general public often are concerned about trace metals, other chemicals, and pathogens in the biosolids and their potential impact on air, water, soil, and food quality. Robinson et al. (2012) concluded that open decision making, communication, trust, public participation, and education of the public is needed for every successful beneficial use program.

Although every community is different and has its own attitudes towards biosolids, an attempt to rank the biosolids treatment processes based on their aesthetics and potential to raise concern regarding potential impacts on human health and the environment was undertaken. The qualitative results that were generated are displayed in the Table 3.2. It is important to note that this ranking should be used as a rough guidance regarding the potential social impacts of biosolids land application programs, because the scores may not reflect the values or concerns that prevail in a given community.

The odor category was difficult to score because the most common and most unpleasant odor comes from reduced sulfur compounds (Becker, North et al. 2003). Composted biosolids produce odors caused by ammonia, amines, sulfur-based compounds, fatty acids, and aromatics (USEPA 2000). Air dried biosolids produce odors caused by small amounts of hydrogen sulfide, mercaptan, and dimethyl sulfide (USEPA 2000). Anaerobic digestion produces odors from hydrogen sulfide and other sulfur containing gases (USEPA 2000). For these reasons, one point was assigned to composting, air drying, lagoon storage, and TPAD in the odor category.

Processes were scored in the noise category based on the amount of time mechanical equipment, such as a front-end loader and windrow turner, is used on site. Composting and air drying both require more movement and mixing of the biosolids so their 'noise' score reflected that. The final volume of biosolids product determined the number of trucks needed to transport the biosolids to the final destination. The more trucks a process required for biosolids transportation, the higher the score in the 'truck traffic' category.

WRRF appearance was scored purely on the size of any outdoors biosolids operations. A point was assigned in the 'dust' category if a treatment process generated a final biosolids product with a very high total solids and/or biosolids were mixed in windrows. Every 
process was assigned one point in the 'concerns about human health and environment' category because the general public is not concerned about the risks with any specific treatment process. Instead, these concerns are with biosolids use in general. Direct heat drying and TPAD have fewer social impacts because they are more contained, engineered technologies. In contrast, air drying, lagoon storage, and composting are performed outdoors, are less controlled, require more space, and therefore could be more prone to social impacts.

Table 3.2. Treatment processes scored with public's concerns. The higher the total score means that there are more social impacts for that process

\begin{tabular}{|l|c|c|c|c|c|}
\hline & Air Drying & $\begin{array}{l}\text { Lagoon } \\
\text { Storage }\end{array}$ & Composting & $\begin{array}{l}\text { Direct } \\
\text { Heat } \\
\text { Drying }\end{array}$ & TPAD \\
\hline Odor & + & + & + & 0 & + \\
\hline Noise & ++ & + & ++ & 0 & 0 \\
\hline Trucks & ++ & ++ & +++ & + & +++ \\
\hline Appearances & + & ++ & + & 0 & 0 \\
\hline Dust & + & + & + & + & 0 \\
\hline $\begin{array}{l}\text { Concern for } \\
\text { human } \\
\text { health and } \\
\text { environment }\end{array}$ & + & + & + & + & + \\
\hline Total & & & & & \\
\hline
\end{tabular}

\subsection{Overall Comparisons}

In order to combine the environmental, economic, and social impacts, each category was normalized and equally weighted. It is important to note that it is highly likely that the three categories of impacts will not be assigned equal weight in the ultimate decisionmaking process undertaken by a community. Instead, the priority given to each category will be dependent on the particular community's experience and objectives.

The overall environmental impacts were normalized by dividing each process's individual score by the largest single score and multiplied by a factor of ten. Therefore, the environmental and social impacts are on a scale of 0 to 10. The economic impacts were divided into capital and O\&M costs and each was normalized to a 0 to 5 scale. This approach is consistent with the "economic ranking based on equally weighted, normalized capital and O\&M costs" in Table 3.1. In this study's framework, the lowest overall score is considered to be the best considering the three aspects of sustainability: environmental, economic, and social.

Using this approach, air drying and TPAD scored the best overall when incorporating environmental, economic, and social impacts (Table 3.3). Lagoon storage came in third with 16.43 points followed by direct heat drying with 17.93 points. Composting has the highest overall due to its high environmental and social impacts and O\&M costs. 
Table 3.3. Overall environmental economic, and social impacts scores based on equally weighed, normalized capital and O\&M costs

\begin{tabular}{|l|c|c|c|c|c|}
\hline & $\begin{array}{c}\text { Air } \\
\text { Drying }\end{array}$ & $\begin{array}{c}\text { Lagoon } \\
\text { Storage }\end{array}$ & Composting & $\begin{array}{c}\text { Direct } \\
\text { Heat } \\
\text { Drying }\end{array}$ & TPAD \\
\hline Environmental & 4.69 & 5.59 & 10.00 & 7.16 & 2.78 \\
\hline $\begin{array}{l}\text { Economic } \\
\text { (Capital Costs) }\end{array}$ & 0.09 & 0.19 & 0.09 & 3.54 & 5.00 \\
\hline $\begin{array}{l}\text { Economic } \\
\text { (O\&M) }\end{array}$ & 1.66 & 1.76 & 5.0 & 3.90 & 2.01 \\
\hline Social & 8.89 & 8.89 & 10 & 3.33 & 5.56 \\
\hline TOTAL & 15.33 & 16.43 & 25.09 & 17.93 & 15.35 \\
\hline
\end{tabular}

If a life cycle cost analysis approach is used in the economic analyses, the outcome of the analysis changes. The economic impacts are calculated by normalizing a 25 -year life cycle assessment of each process on a scale of 0 to 10 instead of ranking the capital cost and initial O\&M separately on scales of 0 to 5 . In this case, air drying is substantially better than TPAD and lagoon storage is actually the second ranked treatment process (rather than instead of third-ranked process). The overall score of composting decreased while the direct heat drying score increased because of the increased importance of capital cost in the life cycle cost analysis.

Table 3.4. Overall environmental economic, and social impacts scores based on a life cycle cost analysis approach

\begin{tabular}{|l|c|c|c|c|c|}
\hline & $\begin{array}{c}\text { Air } \\
\text { Drying }\end{array}$ & $\begin{array}{c}\text { Lagoon } \\
\text { Storage }\end{array}$ & Composting & $\begin{array}{c}\text { Direct } \\
\text { Heat } \\
\text { Drying }\end{array}$ & TPAD \\
\hline Environmental & 4.69 & 5.59 & 10.00 & 7.16 & 2.78 \\
\hline $\begin{array}{l}\text { Economic (life } \\
\text { cycle cost) }\end{array}$ & 0.84 & 1.07 & 2.22 & 8.11 & 10.00 \\
\hline Social & 8.89 & 8.89 & 10 & 3.33 & 5.56 \\
\hline TOTAL & 14.42 & 15.55 & 22.22 & 18.6 & 18.34 \\
\hline
\end{tabular}




\section{Conclusion}

LCLT processes offer small WRRFs a more realistic way for producing Class A biosolids. Conventional treatment processes are energy intensive and costly compared to LCLT processes such as air drying and lagoon storage. Composting and direct heat drying had the most environmental impacts due to composting's biogenic emissions of carbon dioxide, methane, and nitrous oxide and direct heat drying's natural gas requirements. TPAD and direct heat drying had significantly higher capital costs while composting had the highest O\&M cost due to its amendments, labor, and fuel. Lagoon storage, composting, and air drying had the worst social impacts due to their odor, noise, and trucks. When the environmental, economic, and social impacts were normalized and weighed equally, air drying and TPAD scored the best, and composting scored the worst overall. The final rankings are of the baseline assessment of a conservative air drying emissions scenario and 50 miles of one-way transportation. The air drying emissions sensitivity analysis showed that small alteration to the amount of methane and nitrous oxide emissions can decrease or increase the overall IMPACT 2002+ single score by $4 \mathrm{pt}$. The transportation sensitivity analysis showed that TPAD and composting are especially vulnerable to changing the transportation distance.

It is important to note that each WRRF, and their surrounding communities, are all different. The ranking of social impacts and weight of each category in the overall ranking are likely to occur. The distance from the WRRF to the final destination of the biosolids will vary from community to community as well. It is also important to note the limitations in the emissions data available in literature today. More research is needed on the emissions from LCLT processes, especially lagoon storage. It will be hard to have concise emissions data because there are many environmental and biosolids characteristics that vary from WRRF to WRRF that affect the composition of the emissions. The carbon and nitrogen content, moisture, and temperature are just a few factors that determine the emissions composition in the Class A producing processes. 


\section{Reference List}

AgMRC (2018). "Sawdust." Retrieved 5 March 2019, from https://www.agmrc.org/commodities-products/biomass/sawdust.

Agru (2019). "The Influencing Factors of HDPE Liner Cost." Retrieved 6 May 2019, from https://agruamerica.com/hdpe-liner-cost/.

ANL (2018). Greenhouse gases, Regulated Emissions, and Energy use in Transportation (GREET) model, Argonne National Laboratory, Energy Systems Division.

Becker, J. G. and E. A. Seagren (2018). Long-Term Storage and Air Drying Pilot-Scale Studies at GIWA, Michigan Technological University.

Beecher, N., et al. (2007). A National Biosolids Regulation, Quanlity, End Use, and Disposal Survey, North East Biosolids and Residuals Association

BLS (2017). "Occupational Employment and Wages, May 2017: 51-8031 Water and Wastewater Treatment Plant and System Operators." Retrieved 4 April 2019, from https://www.bls.gov/oes/2017/may/oes518031.htm.

Brown, S., et al. (2008). "Greenhouse Gas Balance for Composting Operations." Journal of Environmental Quality 37(4): 1396-1410.

CAPA (2019). "Asphalt Tonnage Calculator." Retrieved 6 May 2019, from https://coasphalt.com/resources/asphalt-tonnage-calculator/.

Caterpiller (2012). "924K, 930K, 938K Wheel Loaders." Retrieved 6 May 2019, from https://s7d2.scene7.com/is/content/Caterpillar/C737355. 
EIA (2019). "Electric Power Monthly." Retrieved 6 May 2019, from https://www.eia.gov/electricity/monthly/epm table_grapher.php?t=epmt 5_6_a.

EIA (2019). "Natural Gas." Retrieved 6 May 2019, from https://www.eia.gov/dnav/ng/ng_pri_sum_dcu_nus_m.htm.

EIA (2019). "Petroleum \& Other Liquids." Retrieved 6 May 2019, from https://www.eia.gov/petroleum/gasdiesel/.

Farrell, J. B., et al. (2004). Producing Class A Biosolids With Low-Cost, LowTechnology Treatment Processes, Water Intelligence Online. 3.

Harris, R. A. and D. R. Phillips (1986). Density of Selected Wood Fuels. South Carolina, Georgia Forest Research Paper.

Hospido, A., et al. (2005). "Environmental Evaluation of Different Treatment Processes for Sludge from Urban Wastewater Treatments: Anaerobic digestion versus Thermal Processes." The International Journal of Life Cycle Assessment 10(5): 336-345.

Humbert, S., et al. (2014). IMPACT 2002+: User Guide. Draft for version Q2.21, Quantis.

ISO (2006). Environmental management -- Life cycle assessment -- Requirements and guidelines, International Organization for Standardization. 14044.

Jackson, T. (2010). "The owning and operating costs of dump trucks." Retrieved 6 May 2019, from https://www.equipmentworld.com/owning-and-operating-costs-8/.

Jolliet, O., et al. (2003). "IMPACT 2002+: A New Life Cycle Impact Assessment Methodology." The International Journal of Life Cycle Assessment 6: 324-330. 
Komilis, D. P. and R. K. Ham (2004). "Life-Cycle Inventory of Municipal Solid Waste and Yard Waste Windrow Composting in the United States." Journal of Environmental Engineering 130(11): 1390-1400.

Li, Z., et al. (2016). "A fuel-based approach for emission factor development for highway paving construction equipment in China." Journal of the Air \& Waste Management Association 66(12): 1214-1223.

Majumder, R., et al. (2014). "Biosolid stockpiles are a significant point source for greenhouse gas emissions." Journal of Environmental Management 143: 34-43.

Metcalf and Eddy (2014). Wastewater Engineering: Treatment and Resource Recovery. Boston, McGraw-Hill Education.

Myhre, G., et al. (2013). Climate Change 2013: The Physical Science Basis. Contribution of Working Group I to the Fifth Assessment Report of the Intergovernmental Panel on Climate Change. Cambridge, United Kingdom, Intergovernmental Panel on Climate Change.

NEBRA (2011). Options for Biosolids Use or Disposal in New England \& Eastern Canada, North East Biosolids and Residuals Association.

Poulsen, T. G. and J. A. Hansen (2003). "Strategic environmental assessment of alternative sewage sludge management scenarios." Waste Management \& Research 21(1): 19-28.

Puchajda, B. and J. Oleszkiewicz (2008). "Impact of sludge thickening on energy recovery from anaerobic digestion." Water Science \& Technology 57(3): 395-401. 
Riau, V., et al. (2010). "Termperature-Phased Anaerobic Digestion (TPAD) to Obtain Class A Biosolids: A Semi-Continuous Study."." Bioresource Technology 101(8): 270627112.

Robinson, K. G., et al. (2012). "Public attitudes and risk perception toward land application of biosolids within the south-eastern United States." Journal of Environmental Management 98: 29-36.

SCAP (2016). California Biosolids Use and Disposal in 2015, Southern California Alliance of Publicly Owned Treatment Works.

Seagren, E. (2019). III. SOLID WASTE, continued. CEE 4511, Solid \& Haz. Waste Engr., Spr. Semester, Michigan Tech E.A Seagren.

Smith, A. (2019). "How Much Does Mulch Delivery Cost?". Retrieved 6 May 2019, from https://www.kompareit.com/homeandgarden/landscaping-compare-mulch-deliverycosts.html.

Smith, J. E. and R. O. Reimers (2006). U.S.A's Practices for Controlling Pathogens in Biosolids. Australian Water Association's Biosolids Specialty III Conference, Melbourne, Australian Water Association.

Spellman, F. R. (1997). Wastewater Biosolids to Compost, Technomic Publishing.

Statista (2019). "Average price of common clay from 2007 to 2018." Retrieved 6 May 2019, from https://www.statista.com/statistics/248190/average-price-of-common-clay/.

Suh, Y.-J. and P. Rousseaux (2002). "An LCA of Alternative Wastewater Sludge Treatment Scenarios." Resources, Conservation and Recycling 35(3): 191-200. 
SYLVIS (2009). The biosolids emissions assessment model (BEAM): A method for determining greenhouse gas emissions from canadian biosolids management practices. Winnipeg, Manitoba, Canadian Council of Ministers of the Environment.

Tiquia, S. M., et al. (2002). "Carbon, nutrient, and mass loss during composting." Nutrient Cycling in Agroecosystems 62(1): 15-24.

USEPA (1974). Process Design Manual for Sludge Treatment and Disposal. Washington D.C., U.S. Environmental Protection Agency.

USEPA (1985). Estimating Sludge Management Costs. Cincinnati, OH, U.S. Environmental Protection Agency.

USEPA (2000). Biosolids and Residuals Management Fact Sheet: Odor Control in Biosolids Management. Washington D.C., U.S. Environmental Protection Agency

USEPA (2000). Biosolids Technology Fact Sheet: Belt Filter Press. Washington D.c., U.S. Environmental Protection Agency

USEPA (2002). Biosolids Technology Fact Sheet: Use of Composting for Biosolids Management. Washington D.C., U.S. Environmental Protection Agency

USEPA (2002). Cost Methodolgy for the Final Revisions to the National Pollutant Discharge Elmination System Regulation and the Effluent Guidelines for Concentrated Animal Feeding Operation. Washington D.C., U.S. Environmental Protection Agency

USEPA (2006). Biosolids Technology Fact Sheet: Heat Drying. Washington D.C., U.S. Environmental Protection Agency. 
USEPA (2006). Biosolids Technology Fact Sheet: Multi-Stage Anaerobic Digestion. Washington D.C., U.S. Environmental Protection Agency.

UW-Madison (1996). "Windrow composting systems can be feasable, cost effective (Research Brief \#20)." Retrieved 6 May 2019, from https:/www.cias.wisc.edu/windrowcomposting-systems-can-be-feasable-cost-effective/.

Vasileski, G. (2007). Beneficial Uses of Municipal Wastewater Residuals - Biosolids, Canadian Water and Wastewater Association.

Walker, J., et al. (1994). A Plain English Guide to the EPA Part 503 Biosolids Rule. Washington D.C., U.S. Environmental Protection Agency.

Wang, L. K., et al. (2007). Biosolids Treatment Processes. Totowa, New Jersey, Humana Press.

Weidema, B. P., et al. (2013). Overview and methodology: Data quality guideline for the ecoinvent database version 3. St. Gallen: The ecoinvent Centre, Swiss Centre for Life Cycle Inventories.

Yamulki, S. (2006). "Effect of straw on nitrous oxide and methane emissions from stored farmyard manure." Agriculture, Ecosystems \& Environment 112(2-3): 140-145. 


\section{A Appendix}

\section{A.1 Air Dry Calculations}

Mechanical dewatering

\section{Electricity}

EPA belt filter press electricity usage algorithm (USEPA 1985)

$\mathrm{E}=\left[-5.42\left(\mathrm{TBFW}^{3}\right)+234.6\left(\mathrm{TBFW}^{2}\right)+16,020(\mathrm{TBFW})+13,997\right]$ (Metcalf and Eddy 2014)

Where:

- $\quad \mathrm{E}=$ Annual electrical energy required $(\mathrm{kWhr} / \mathrm{yr}) * *$

- $\quad$ TBFW $=$ Total belt filter width (m)

**assumes $8 \mathrm{hr}$ work days for 365 operational days/yr

$E=[-5.42(1 \mathrm{~m})+234.6(1 \mathrm{~m})+16,020(1 \mathrm{~m})+13,997=30,246 \mathrm{kWh} / \mathrm{yr}$

Daily electricity use $=30,246 \frac{\mathrm{kWh}}{\mathrm{yr}} * \frac{1 \mathrm{yr}}{365 \text { days }}=82.9 \mathrm{kWh} /$ day

$$
\begin{aligned}
\text { Electricity Use per FU } & =\frac{82.9 \mathrm{kWh}}{\text { day }} * \frac{2 \text { operational day }}{\text { week }} * \frac{52 \text { week }}{1 \mathrm{yr}} * \frac{1 \mathrm{yr}}{200 \text { dry ton }} \\
= & 43.1 \frac{\mathrm{kWh}}{\text { dry ton }}
\end{aligned}
$$

\section{Belt Filter Press sizing}

Given

- $\quad$ Loading rate $=700$ dry lbs per hour per meter of width (Metcalf and Eddy 2014)

- $\quad$ Work week $=2$ day per week

- $\quad$ Work day $=8 \mathrm{hrs} /$ day

Daily rate $($ dry $)=$ Weight of dry solids $* \frac{2,000 \mathrm{lb}}{1 \text { ton }} * \frac{1 \mathrm{yr}}{365 \text { days }}$

$$
=\frac{230 \text { dry ton }}{\text { year }} * \frac{2,000 \mathrm{lb}}{1 \text { ton }} * \frac{1 \mathrm{yr}}{365 \text { days }}=1,260.3 \frac{\mathrm{lb}}{\text { day }}
$$


Operational daily rate $($ dry $)=$ daily rate $* \frac{7 \text { days }}{1 \text { week }} * \frac{1 \text { week }}{2 \text { operational days }}$

$$
=\frac{1,260 \mathrm{lb}}{\text { day }} * \frac{7 \text { days }}{\text { week }} * \frac{1 \text { week }}{2 \text { operational day }}=4,411 \frac{\mathrm{lb}}{\text { operational day }}
$$

Hourly rate $=\frac{\text { operational daily rate (dry) }}{\text { hours per work day }}=\frac{\frac{4,411 \mathrm{lb}}{\text { operational day }}}{\frac{8 \text { hours }}{\text { operational day }}}=551 \frac{\mathrm{lb}}{\mathrm{hr}}$

Belt Width $=\frac{\text { hourly rate }}{\text { loading rate }}=\frac{551 \frac{\mathrm{lb}}{\mathrm{hr}}}{700 \frac{\mathrm{lb}}{\mathrm{hr} \mathrm{m}}}=0.8 \mathrm{~m}$

Round up to the next commercially available size $=1.0 \mathrm{~m}$

\section{Wash water}

Wash water needed $=50$ gallons per minute per meter of belt width (Metcalf and Eddy 2014)

Wash water needed $=\frac{50 \text { gal }}{\text { minute }} * \frac{60 \text { minutes }}{1 \mathrm{hr}} * \frac{8 \text { hours }}{1 \text { work day }} * \frac{104 \text { work days }}{1 \mathrm{yr}}$

$$
=2,496,000 \frac{\text { gallons }}{\text { year }}
$$

Wash water needed $=\frac{\frac{2,496,000 \text { gallons }}{\text { year }}}{\frac{200 \text { dry tons }}{\mathrm{yr}}}=12,480 \frac{\text { gallons }}{\text { final dry tons }}$

\section{Polymer}

Polymer $=6 \mathrm{~g} / \mathrm{dry}$ kg solids (Metcalf and Eddy 2014) 


$$
\begin{array}{r}
\text { polymer }=\frac{6 \text { g polymer }}{\text { kg dry solids }} * \frac{1 \mathrm{~kg}}{2.2 \mathrm{lb}} * \frac{2,000 \mathrm{lb}}{1 \mathrm{ton}} \\
=5,454.5 \mathrm{~g} \text { polymer per ton of dry solids }
\end{array}
$$

$$
\begin{gathered}
\text { polymer }=\frac{5,454.5 \mathrm{~g} \text { polymer }}{1 \text { ton dry solids }} * \frac{1 \mathrm{~kg}}{1000 \mathrm{~g}} * \frac{2.2 \mathrm{lb}}{1 \mathrm{~kg}} * \frac{230 \text { ton dry solids }}{1 \mathrm{yr}} \\
=2760 \mathrm{lb} \text { polymer per year }
\end{gathered}
$$

$\frac{2760 \mathrm{lb} \text { polymer }}{\mathrm{yr}} * \frac{1 \mathrm{yr}}{200 \mathrm{dry} \text { tons }}=14 \mathrm{lb}$ polymer per dry ton

\section{Water for polymer dilution}

$0.5 \%$ dilution of polymer needed

$$
\begin{gathered}
\frac{\left(\frac{5454 \text { g polymer }}{\text { dry ton }}\right)}{\frac{0.5 \text { g polymer }}{100 \text { g water }} * \frac{1000 \mathrm{~g}}{1 \mathrm{~kg}} * \frac{1000 \mathrm{~kg}}{1 \mathrm{~m}^{3}} * \frac{1 \mathrm{~m}^{3}}{35.3 \mathrm{ft}^{3}} * \frac{1 \mathrm{ft}^{3}}{7.48 \mathrm{gal}}} * \frac{230 \text { dry tons }}{\mathrm{yr}} \\
* \frac{\mathrm{yr}}{200 \text { final dry tons }}=331 \text { gal water per dry ton solids }
\end{gathered}
$$

\section{Filtrate}

Filtrate (water removed from biosolids) calculated using a mass balance (wet tons before BFP - wet tons after BFP) $=$

$$
\begin{aligned}
\left(\frac{5111 \text { tons }}{\mathrm{yr}}-\right. & \left.\frac{1045 \text { tons }}{\mathrm{yr}}\right) *\left(\frac{2,000 \mathrm{lb}}{1 \mathrm{ton}} * \frac{1 \mathrm{ft}^{3}}{62.4 \mathrm{lb}} * \frac{7.48 \mathrm{gal}}{1 \mathrm{ft}^{3}}\right) * \frac{1 \mathrm{yr}}{200 \text { dry tons }} \\
& =4,874 \frac{\mathrm{gal}}{\text { dry ton }}
\end{aligned}
$$

Air Drying

\section{Diesel fuel for dump truck transportation from BFP to air drying pad}


Given

- $\quad$ Assumption $=2,000 \mathrm{ft}$ to air drying cell

- $\quad$ Dump truck fuel use $=3.2 \mathrm{mpg}$

- Dump truck size $=20$ cyd

- $\quad$ Total quantity of biosolids $=1,045$ tons/yr (see TS \& VS tab)

- $\quad$ Total volume of biosolids $=43,561 \mathrm{ft} 3$ (

- Belt filter runs 104 days per year

Quantity of biosolids per operational day $=\frac{1045 \frac{\text { tons }}{\mathrm{yr}}}{104 \frac{\mathrm{runs}}{\mathrm{yr}}}=10.1 \frac{\text { tons }}{\mathrm{run}}$

Volume of biosolids per operational day $=\frac{43,561 \frac{\mathrm{ft} 3}{\mathrm{yr}}}{104 \frac{\mathrm{runs}}{\mathrm{yr}}}=418.9 \frac{\mathrm{ft} 3}{\mathrm{run}}$

Volume of biosolids per operational day $=418.9 \frac{\mathrm{ft} 3}{\mathrm{run}} * \frac{1 \mathrm{yd}^{3}}{27 \mathrm{ft}^{3}}=16 \frac{\mathrm{yd}^{3}}{\text { run }}$

Trip to and from pad $=\frac{\text { Volume of biosolids per run }}{\text { dump truck size }}=\frac{16 \text { cyd }}{20 \text { cyd }} \approx 1$

Total distance $=2 *$ trips to and from pad $*$ distance to pad $=2 * 1 * 2,000 \mathrm{ft}$ $=4,000 \mathrm{ft}$

Total distance $=\frac{4,000 \mathrm{ft}}{5,280 \frac{\mathrm{ft}}{\mathrm{mile}}}=0.76$ miles

Diesel Usage $=\frac{\text { total distance }}{\text { fuel use }}=\frac{1.52 \mathrm{miles}}{3.2 \mathrm{mpg}} * \frac{3.785 \mathrm{l}}{1 \text { gal }}=0.9 \frac{\text { liters }}{\text { operational day }}$

diesel usage per year $=\frac{0.9 \text { liters }}{\text { operational day }} * \frac{104 \text { operational days }}{1 \mathrm{yr}}=93.6 \frac{\text { liters }}{\mathrm{yr}}$ 
Diesel per dry ton $=\frac{93.6 \frac{\text { liters }}{\mathrm{yr}}}{\frac{200 \text { final dry tons }}{\mathrm{yr}}}=0.47 \frac{\text { liters of diesel }}{\text { dry ton }}$

\section{Diesel fuel for front end loader to place biosolids in windrows}

Given:

- $\quad$ Bucket size $=3$ cyd

- Time to scoop up biosolids and form windrows per scoop $=5$ minutes

- $\quad$ Medium fuel burn mileage $=0.12$ liters/minute (Caterpiller 2012)

Fuel needed $=$ time $*$ mileage $=5$ minutes $* \frac{0.12 \text { liters }}{\text { minute }}=0.60$ liters $/$ run

Runs per pressing $=\frac{\text { Volume }}{\text { bucket size }}=\frac{16 \text { cyd }}{3 \text { cyd }}=6$ runs

Total fuel use per operational day $=0.60 \frac{\text { Liters }}{\text { run }} * 6$ runs $=3.6$ liters

Total fuel per year $=\frac{\text { total fuel }}{\text { operational day }} * \frac{\text { operational days }}{\text { year }}$

$$
=3.6 \text { liters } * 104 \frac{\text { operational days }}{\mathrm{yr}}=374.4 \text { liters }
$$

Diesel fuel per dry ton $=\frac{\text { Total fuel per year }}{\text { FU }}=\frac{374.4 \text { liters }}{200 \frac{\text { dry ton }}{\mathrm{yr}}}$

$$
=1.87 \text { liters of diesel per dry ton }
$$

\section{Diesel fuel for turning windrows}

Given: 0.1 L diesel per ton (Komilis and Ham 2004). This assumes turning once a week for 4 weeks

$\frac{0.1 \mathrm{~L}}{\text { ton } * 4 \text { weeks }} * 10$ weeks $=0.25 \frac{\mathrm{L}}{\text { ton }}$

$\frac{0.25 \mathrm{~L}}{\text { ton }} * \frac{1045 \text { tons at start of air drying }}{1 \mathrm{yr}} * \frac{1 \mathrm{yr}}{200 \text { dry tons }}=1.31 \mathrm{~L}$ diesel per dry ton 


\section{Asphalt mix for pad}

Given:

- Windrow height $=2 \mathrm{ft}$

- $\quad$ Windrow width $=7 \mathrm{ft}$

- Equipment clearance width $=5 \mathrm{ft}$

- $\quad$ End Clearance (length) $=7 \mathrm{ft}$

- $\quad$ Cycle duration $=10$ weeks

- Cycles per year $=2$

- $\quad$ Initial volume of sludge $=43,561 \mathrm{ft} 3$ (see TS \& VS tab)

Assumptions:

- Windrows can be formed at $22 \%$ solids instead of the recommended $30 \%$ solids

- 12 windrows

- Depth of asphalt is $0.5 \mathrm{ft}$

- Lifetime of pad is 25 years

- Asphalt is 90\% gravel, 10\% asphalt adhesive

Volume per cycle $=\frac{\text { Initial sludge volume }}{\text { cycles per year }}=\frac{43,561 \frac{\mathrm{ft}^{3}}{\mathrm{yr}}}{2 \frac{\text { cycles }}{\mathrm{yr}}}=21,780 \mathrm{ft}^{3}$

Width of windrow + equipment clearance $=7 \mathrm{ft}+5 \mathrm{ft}=12 \mathrm{ft}$

Cross Section of windrow $=\frac{1}{2}$ base $*$ height $=0.5 * 7 \mathrm{ft} * 2 \mathrm{ft}=7 \mathrm{ft}^{2}$

$$
\begin{aligned}
\text { Length of pad } & =\frac{\text { Volume }}{\text { cross section of windrow } * \text { number of windrow rows }}=\frac{21780 \mathrm{ft}^{3}}{12 * 7 \mathrm{ft}^{2}} \\
& =259 \mathrm{ft}
\end{aligned}
$$

Length with end clearance $=259 \mathrm{ft}+7 \mathrm{ft} * 2=273 \mathrm{ft}$

Width with extra $5^{\prime}=12 * 12 \mathrm{ft}+5 \mathrm{ft}=149 \mathrm{ft}$

Tonnage of asphalt calculated using an online calculator with dimensions and compaction. (CAPA 2019)

Asphalt $=1,491$ tons 
Dry ton of biosolids per lifetime $=\mathrm{FU} *$ lifetime $=\frac{200 \text { dry tons }}{\text { year }} * 25 \mathrm{yr}$ $=5,000$ dry tons

Ashpalt per dry ton $=\frac{980 \text { ton asphalt }}{5,000 \text { dry tons/lifetime }}=0.30 \frac{\text { tons asphalt }}{\text { dry ton }}$

Gravel $=0.9 * 0.30 \frac{\text { tons asphalt }}{\text { dry ton }}=0.27 \frac{\text { tons gravel }}{\text { dry ton }}$

Asphalt adhesive $=0.1 * 0.30 \frac{\text { tons asphalt }}{\text { dry ton }}=0.03 \frac{\text { tons asphalt adhesive }}{\text { dry ton }}$

\section{Emissions}

Given

$-\mathrm{C} / \mathrm{N}$ ratio $=15.6($ Seagren 2019$)$
$-\% \mathrm{~N}=1.88 \%($ Seagren 2019$)$
$\% \mathrm{C}=\frac{\% \mathrm{~N}}{100} * \mathrm{C}: \mathrm{N}$ ratio $=\frac{1.88}{100} * 15.6=29.3 \%$

Carbon content $=\left(\frac{\% \mathrm{C}}{100}\right) *$ dry wt $=\frac{29.3}{100} * 230 \frac{\mathrm{dry} \text { ton }}{\mathrm{yr}}=67.5 \frac{\mathrm{ton} \mathrm{C}}{\mathrm{yr}}$

Nitrogen Content $=\left(\frac{\% \mathrm{~N}}{100}\right) *$ dry wt $=\left(\frac{1.88}{100}\right) * 230 \frac{\mathrm{dry} \text { ton }}{\mathrm{yr}}=4.3 \frac{\mathrm{ton} \mathrm{N}}{\mathrm{yr}}$

A sensitivity analysis was done using the following three scenarios:

Scenario1 (conservative)(baseline):

- Methane loss $=3.8 \%$ of initial carbon content

- $\quad \mathrm{N} 2 \mathrm{O}$ loss $=0.87 \%$ of initial nitrogen content

Scenario 2 (intermediate):

- Methane loss $=2.85 \%$ of initial carbon content

- $\quad \mathrm{N} 2 \mathrm{O}$ loss $=0.74 \%$ of initial nitrogen content

Scenario 3 (composting like)

- Methane loss $=1.9 \%$ of initial carbon content (Brown, Kruger et al. 2008)

- $\quad \mathrm{N} 2 \mathrm{O}$ loss $=0.6 \%$ of initial nitrogen content (Brown, Kruger et al. 2008) 
Yamulki (2006) study that added straw (nutrient amendment) to manure heaps and found that the $\mathrm{CH} 4$ and $\mathrm{N} 2 \mathrm{O}$ emissions decreased because the straw increased the $\mathrm{C} / \mathrm{N}$ ratio. $\mathrm{CH} 4$ reduced from $0.06 \%$ of loss of $\mathrm{C}$ as $\mathrm{CH} 4$ to $0.03 \%$ of loss of $\mathrm{C}$ as $\mathrm{CH} 4$. N2O reduced from $0.7 \%$ of loss of $\mathrm{N}$ as $\mathrm{N} 2 \mathrm{O}$ to $0.48 \%$ of loss of $\mathrm{N}$ as $\mathrm{N} 2 \mathrm{O}$.

\%increase $=\frac{0.06-0.03}{0.03} * 100=100 \%$ increase in $\mathrm{CH} 4$ emissions

\%increase $=\frac{0.07-0.048}{0.048} * 100=46 \%$ increase in $\mathrm{CH} 4$ emissions

Conservative methane loss $=1.9 *\left(1+\frac{100}{100}\right)=3.8 \%$ of initial carbon content

Conservative nitrous oxide loss $=0.6 *\left(1+\frac{46}{100}\right)$

$$
=0.87 \% \text { of initial nitrogen content }
$$

Intermediate methane loss $=\frac{3.8+1.9}{2}=2.85 \%$

Intermediate nitrous oxide loss $=\frac{0.87+0.6}{2}=0.74 \%$

Total carbon loss $=57 \%$ (Tiquia, Richard et al. 2002)

Scenario 1

$\mathrm{N} 2 \mathrm{O}$ released $=$ initial $\mathrm{N}$ dry $\mathrm{wt} . * \% \mathrm{~N}$ loss $=\frac{4.3 \text { ton } \mathrm{N}}{\mathrm{yr}} * \frac{0.87}{100}=0.0378 \frac{\text { ton } \mathrm{N} \text { as N2O }}{\mathrm{yr}}$

$\mathrm{CH} 4$ released $=$ inital C dry wt. $*$ C loss $=\frac{67.5 \text { ton C }}{\mathrm{yr}} * \frac{3.8}{100}=2.56 \frac{\operatorname{ton} \mathrm{C} \text { as } \mathrm{CH} 4}{\mathrm{yr}}$

Total Carbon loss $=$ Carbon content $* \%$ Carbon loss $=67.5 \frac{\operatorname{ton} \mathrm{C}}{\mathrm{yr}} *\left(\frac{57}{100}\right)=38.4 \frac{\text { ton } \mathrm{C}}{\mathrm{yr}}$

Carbon dioxide released $=$ total $\mathrm{C}$ released $-\mathrm{C}$ released as $\mathrm{CH} 4=38.4 \frac{\text { ton } \mathrm{C}}{\mathrm{yr}}-$

$2.56 \frac{\text { ton } \mathrm{C} \text { as } \mathrm{CH} 4}{\mathrm{yr}}=35.9 \frac{\text { ton } \mathrm{C} \text { as } \mathrm{CO} 2}{\mathrm{yr}}$ 
$\mathrm{N} 2 \mathrm{O}$ released per dry ton $=\frac{0.0378 \text { ton } \mathrm{N} \text { as N2O }}{\mathrm{yr}} * \frac{2000 \mathrm{lb}}{1 \mathrm{ton}} * \frac{1 \mathrm{~kg}}{2.2 \mathrm{lb}} * \frac{1 \mathrm{kmol} \mathrm{N}}{14 \mathrm{~kg}} * \frac{1 \mathrm{kmol} \mathrm{N} 2 \mathrm{O}}{2 \mathrm{kmol} \mathrm{N}} *$ $\frac{44 \mathrm{~kg} \mathrm{~N} 2 \mathrm{O}}{1 \mathrm{kmol} \mathrm{N} 2 \mathrm{O}} * \frac{1 \mathrm{yr}}{200 \text { dry ton }}=0.27 \frac{\mathrm{kg} \mathrm{N} 2 \mathrm{O}}{\text { dry ton }}$

$\mathrm{CH} 4$ released per dry ton $=\frac{2.56 \text { ton } \mathrm{C} \text { as } \mathrm{CO} 2}{\mathrm{yr}} * \frac{2000 \mathrm{lb}}{1 \mathrm{ton}} * \frac{1 \mathrm{~kg}}{2.2 \mathrm{lb}} * \frac{1 \mathrm{kmol} \mathrm{C}}{12 \mathrm{~kg}} * \frac{1 \mathrm{kmol} \mathrm{CH} 4}{1 \mathrm{kmol} \mathrm{C}} *$ $\frac{16 \mathrm{~kg} \mathrm{CH} 4}{1 \mathrm{kmol} \mathrm{CH} 4} * \frac{1 \mathrm{yr}}{200 \text { dry ton }}=15.5 \frac{\mathrm{kg} \mathrm{CH} 4}{\text { dry ton }}$

$\mathrm{CO} 2$ released per dry ton $=\frac{35.9 \text { ton } \mathrm{C} \text { as } \mathrm{CO} 2}{\mathrm{yr}} * \frac{2000 \mathrm{lb}}{1 \mathrm{ton}} * \frac{1 \mathrm{~kg}}{2.2 \mathrm{lb}} * \frac{1 \mathrm{kmol} \mathrm{C}}{12 \mathrm{~kg}} * \frac{1 \mathrm{kmol} \mathrm{CO} 2}{1 \mathrm{kmol} \mathrm{C}} *$ $\frac{44 \mathrm{~kg} \mathrm{CO} 2}{1 \mathrm{kmol} \mathrm{CO} 2} * \frac{1 \mathrm{yr}}{200 \text { dry ton }}=598.1 \frac{\mathrm{kg} \mathrm{CO} 2}{\text { dry ton }}$

Scenario 2

$\mathrm{N} 2 \mathrm{O}$ released $=$ initial $\mathrm{N}$ dry $\mathrm{wt} . * \% \mathrm{~N}$ loss $=\frac{4.3 \text { ton } \mathrm{N}}{\mathrm{yr}} * \frac{0.74}{100}=0.0319 \frac{\text { ton } \mathrm{N} \text { as N2O }}{\mathrm{yr}}$

$\mathrm{CH} 4$ released $=$ inital C dry wt. $*$ C loss $=\frac{67.5 \text { ton C }}{\mathrm{yr}} * \frac{2.85}{100}=1.92 \frac{\operatorname{ton} \mathrm{C} \text { as } \mathrm{CH} 4}{\mathrm{yr}}$

Total Carbon loss $=$ Carbon content $* \%$ Carbon loss $=67.5 \frac{\operatorname{ton} \mathrm{C}}{\mathrm{yr}} *\left(\frac{57}{100}\right)=38.4 \frac{\text { ton C }}{\mathrm{yr}}$

Carbon dioxide released $=$ total $\mathrm{C}$ released $-\mathrm{C}$ released as $\mathrm{CH} 4=38.4 \frac{\text { ton } \mathrm{C}}{\mathrm{yr}}-$

$1.92 \frac{\text { ton } \mathrm{C} \text { as } \mathrm{CH} 4}{\mathrm{yr}}=36.5 \frac{\text { ton } \mathrm{C} \text { as } \mathrm{CO} 2}{\mathrm{yr}}$

$\mathrm{N} 2 \mathrm{O}$ released per dry ton $=\frac{0.0319 \text { ton } \mathrm{N} \text { as N2O }}{\mathrm{yr}} * \frac{2000 \mathrm{lb}}{1 \mathrm{ton}} * \frac{1 \mathrm{~kg}}{2.2 \mathrm{lb}} * \frac{1 \mathrm{kmol} \mathrm{N}}{14 \mathrm{~kg}} * \frac{1 \mathrm{kmol} \mathrm{N} 2 \mathrm{O}}{2 \mathrm{kmol} \mathrm{N}} *$

$\frac{44 \mathrm{~kg} \mathrm{~N} 2 \mathrm{O}}{1 \mathrm{kmol} \mathrm{N} 2 \mathrm{O}} * \frac{1 \mathrm{yr}}{200 \text { dry ton }}=0.23 \frac{\mathrm{kg} \mathrm{N} 2 \mathrm{O}}{\text { dry ton }}$

$\mathrm{CH} 4$ released per dry ton $=\frac{1.93 \text { ton } \mathrm{C} \text { as } \mathrm{CO} 2}{\mathrm{yr}} * \frac{2000 \mathrm{lb}}{1 \mathrm{ton}} * \frac{1 \mathrm{~kg}}{2.2 \mathrm{lb}} * \frac{1 \mathrm{kmol} \mathrm{C}}{12 \mathrm{~kg}} * \frac{1 \mathrm{kmol} \mathrm{CH} 4}{1 \mathrm{kmol} \mathrm{C}} *$ $\frac{16 \mathrm{~kg} \mathrm{CH} 4}{1 \mathrm{kmol} \mathrm{CH} 4} * \frac{1 \mathrm{yr}}{200 \text { dry ton }}=11.7 \frac{\mathrm{kg} \mathrm{CH} 4}{\text { dry ton }}$ 
$\mathrm{CO} 2$ released per dry ton $=\frac{36.5 \text { ton } \mathrm{C} \text { as } \mathrm{CO} 2}{\mathrm{yr}} * \frac{2000 \mathrm{lb}}{1 \mathrm{ton}} * \frac{1 \mathrm{~kg}}{2.2 \mathrm{lb}} * \frac{1 \mathrm{kmol} \mathrm{C}}{12 \mathrm{~kg}} * \frac{1 \mathrm{kmol} \mathrm{CO} 2}{1 \mathrm{kmol} \mathrm{C}} *$ $\frac{44 \mathrm{~kg} \mathrm{CO} 2}{1 \mathrm{kmol} \mathrm{CO} 2} * \frac{1 \mathrm{yr}}{200 \text { dry ton }}=608.8 \frac{\mathrm{kg} \mathrm{CO} 2}{\text { dry ton }}$

Scenario 3

$\mathrm{N} 2 \mathrm{O}$ released $=$ initial $\mathrm{N}$ dry $\mathrm{wt} . * \mathrm{~N}$ loss $=\frac{4.3 \text { ton } \mathrm{N}}{\mathrm{yr}} * \frac{0.60}{100}=0.026 \frac{\text { ton } \mathrm{N} \text { as N2O }}{\mathrm{yr}}$

$\mathrm{CH} 4$ released $=$ inital C dry wt. $* \% \mathrm{C}$ loss $=\frac{67.5 \text { ton } \mathrm{C}}{\mathrm{yr}} * \frac{1.9}{100}=1.28 \frac{\text { ton } \mathrm{C} \text { as } \mathrm{CH} 4}{\mathrm{yr}}$

Total Carbon loss $=$ Carbon content $* \%$ Carbon loss $=67.5 \frac{\operatorname{ton} \mathrm{C}}{\mathrm{yr}} *\left(\frac{57}{100}\right)=38.4 \frac{\text { ton C }}{\mathrm{yr}}$

Carbon dioxide released $=$ total $\mathrm{C}$ released $-\mathrm{C}$ released as $\mathrm{CH} 4=38.4 \frac{\text { ton } \mathrm{C}}{\mathrm{yr}}-$

$1.28 \frac{\text { ton } \mathrm{C} \text { as } \mathrm{CH} 4}{\mathrm{yr}}=37.2 \frac{\text { ton } \mathrm{C} \text { as } \mathrm{CO} 2}{\mathrm{yr}}$

$\mathrm{N} 2 \mathrm{O}$ released per dry ton $=\frac{0.026 \text { ton } \mathrm{N} \text { as N2O }}{\mathrm{yr}} * \frac{2000 \mathrm{lb}}{1 \mathrm{ton}} * \frac{1 \mathrm{~kg}}{2.2 \mathrm{lb}} * \frac{1 \mathrm{kmol} \mathrm{N}}{14 \mathrm{~kg}} * \frac{1 \mathrm{kmol} \mathrm{N} 2 \mathrm{O}}{2 \mathrm{kmol} \mathrm{N}} *$

$\frac{44 \mathrm{~kg} \mathrm{~N} 2 \mathrm{O}}{1 \mathrm{kmol} \mathrm{N} 2 \mathrm{O}} * \frac{1 \mathrm{yr}}{200 \text { dry ton }}=0.19 \frac{\mathrm{kg} \mathrm{N} 2 \mathrm{O}}{\text { dry ton }}$

$\mathrm{CH} 4$ released per dry ton $=\frac{1.28 \text { ton } \mathrm{C} \text { as } \mathrm{CO} 2}{\mathrm{yr}} * \frac{2000 \mathrm{lb}}{1 \mathrm{ton}} * \frac{1 \mathrm{~kg}}{2.2 \mathrm{lb}} * \frac{1 \mathrm{kmol} \mathrm{C}}{12 \mathrm{~kg}} * \frac{1 \mathrm{kmol} \mathrm{CH} 4}{1 \mathrm{kmol} \mathrm{C}} *$

$\frac{16 \mathrm{~kg} \mathrm{CH} 4}{1 \mathrm{kmol} \mathrm{CH} 4} * \frac{1 \mathrm{yr}}{200 \text { dry ton }}=7.8 \frac{\mathrm{kg} \mathrm{CH} 4}{\text { dry ton }}$

$\mathrm{CO} 2$ released per dry ton $=\frac{37.2 \text { ton } \mathrm{C} \text { as } \mathrm{CO} 2}{\mathrm{yr}} * \frac{2000 \mathrm{lb}}{1 \mathrm{ton}} * \frac{1 \mathrm{~kg}}{2.2 \mathrm{lb}} * \frac{1 \mathrm{kmol} \mathrm{C}}{12 \mathrm{~kg}} * \frac{1 \mathrm{kmol} \mathrm{CO} 2}{1 \mathrm{kmol} \mathrm{C}} *$

$\frac{44 \mathrm{~kg} \mathrm{CO} 2}{1 \mathrm{kmol} \mathrm{CO} 2} * \frac{1 \mathrm{yr}}{200 \text { dry ton }}=619.5 \frac{\mathrm{kg} \mathrm{CO} 2}{\text { dry ton }}$

Transportation@60\% solids

Distance $=50$ miles $=80$ kilometers

Quantity of biosolids $=\frac{333 \text { wet tons }}{\mathrm{yr}} * \frac{1 \text { tonne }}{1.10231 \text { ton }}=302 \frac{\text { tonnes }}{\mathrm{yr}}$ 
Mass Traveled $=\frac{302 \text { tonnes }}{\mathrm{yr}} * 80$ kilometers $=24,332$ tkm per year

Volume $=15,972 \mathrm{ft}^{3} * \frac{1 \text { cyd }}{27 \mathrm{ft}^{3}}=592$ cyd

Size of truck $=20$ cyd

Weighted trucks per cycle $=\frac{592 \frac{\mathrm{cyd}}{\mathrm{cycle}}}{20 \mathrm{cyd}}=30$ trips

\section{A.1.1 Air Drying Detailed Results}

Table A.1.1. Air drying unit process breakdown by inputs and outputs

\begin{tabular}{|l|l|l|l|l|l|}
\hline & $\begin{array}{l}\text { Human } \\
\text { Health }\end{array}$ & $\begin{array}{l}\text { Ecosystem } \\
\text { Quality }\end{array}$ & $\begin{array}{l}\text { Climate } \\
\text { Change }\end{array}$ & Resources & Total \\
\hline Diesel Fuel & 0.1 & 0 & 0 & 2.2 & 0.3 \\
\hline $\begin{array}{l}\text { Biogenic } \\
\text { Methane }\end{array}$ & 0 & 0 & 12.1 & 0 & 12.1 \\
\hline $\begin{array}{l}\text { Biogenic } \\
\text { Carbon } \\
\text { Dioxide }\end{array}$ & 0 & 0 & 8.8 & 0 & 8.8 \\
\hline $\begin{array}{l}\text { Biogenic } \\
\text { Nitrous } \\
\text { Oxide }\end{array}$ & 0 & 0 & 1.4 & 0 & 1.4 \\
\hline $\begin{array}{l}\text { Fossil } \\
\text { Carbon } \\
\text { Dioxide }\end{array}$ & 0 & 0 & 0.2 & 0 & 0.2 \\
\hline Asphalt Mix & 0.5 & 0.1 & 0.4 & 2.0 & 3.0 \\
\hline Total & $\mathbf{0 . 6}$ & $\mathbf{0 . 1}$ & $\mathbf{2 3}$ & $\mathbf{2 . 2}$ & $\mathbf{2 5 . 8}$ \\
\hline
\end{tabular}

\section{A.2 Lagoon Storage Calculations}

\section{Belt Filter Press}

\section{Electricity}

EPA belt filter press electricity usage algorithm 
$\mathrm{E}=\left[-5.42\left(\mathrm{TBFW}^{3}\right)+234.6\left(\mathrm{TBFW}^{2}\right)+16,020(\mathrm{TBFW})+13,997\right]($ USEPA 1985)

Where:

- $\quad \mathrm{E}=$ Annual electrical energy required $(\mathrm{kWhr} / \mathrm{yr}) * *$

- $\quad$ TBFW $=$ Total belt filter width (m)

**assumes $8 \mathrm{hr}$ work days for 365 operational days/yr

$E=[-5.42(1 m)+234.6(1 m)+16,020(1 m)+13,997=30,246 \mathrm{kWh} / \mathrm{yr}$

Daily electricity use $=30,246 \frac{\mathrm{kWh}}{\mathrm{yr}} * \frac{1 \mathrm{yr}}{365 \text { days }}=82.9 \mathrm{kWh} /$ day

$$
\begin{aligned}
\text { Electricity Use per } \mathrm{FU} & =\frac{82.9 \mathrm{kWh}}{\text { day }} * \frac{2 \text { operational day }}{\text { week }} * \frac{52 \text { week }}{1 \mathrm{yr}} * \frac{1 \mathrm{yr}}{200 \text { dry ton }} \\
= & 43.1 \frac{\mathrm{kWh}}{\text { dry ton }}
\end{aligned}
$$

\section{Belt Filter Press Sizing}

Given

- Loading rate $=700$ dry lbs per hour per meter of width (Metcalf and Eddy 2014)

- Work week $=2$ day per week

- Work day $=8 \mathrm{hrs} /$ day

Daily rate (dry) $=$ Weight of dry solids $* \frac{2,000 \mathrm{lb}}{1 \text { ton }} * \frac{1 \mathrm{yr}}{365 \text { days }}$

$$
=\frac{251 \text { dry ton }}{\text { year }} * \frac{2,000 \mathrm{lb}}{1 \text { ton }} * \frac{1 \mathrm{yr}}{365 \text { days }}=1,375 \frac{\mathrm{lb}}{\text { day }}
$$

Operational daily rate $($ dry $)=$ daily rate $* \frac{7 \text { days }}{1 \text { week }} * \frac{1 \text { week }}{2 \text { operational days }}$

$$
=\frac{1375 \mathrm{lb}}{\text { day }} * \frac{7 \text { days }}{\text { week }} * \frac{1 \text { week }}{2 \text { operational day }}=4814 \frac{\mathrm{lb}}{\text { operational day }}
$$

Hourly rate $=\frac{\text { operational daily rate (dry) }}{\text { hours per work day }}=\frac{\frac{4814 \mathrm{lb}}{\text { operational day }}}{\frac{8 \text { hours }}{\text { operational day }}}=602 \frac{\mathrm{lb}}{\mathrm{hr}}$ 
Belt Width $=\frac{\text { hourly rate }}{\text { loading rate }}=\frac{602 \frac{\mathrm{lb}}{\mathrm{hr}}}{700 \frac{\mathrm{lb}}{\mathrm{hr} \mathrm{m}}}=0.86 \mathrm{~m}$

Round up to the next commercially available size $=1.0 \mathrm{~m}$

\section{Wash Water}

Wash water needed $=50$ gallons per minute per meter of belt width (Metcalf and Eddy 2014)

Wash water needed $=\frac{50 \text { gal }}{\text { minute }} * \frac{60 \text { minutes }}{1 \mathrm{hr}} * \frac{8 \text { hours }}{1 \text { work day }} * \frac{104 \text { work days }}{1 \mathrm{yr}}$

$$
=2,496,000 \frac{\text { gallons }}{\text { year }}
$$

Wash water needed $=\frac{\frac{2,496,000 \text { gallons }}{\text { year }}}{\frac{200 \mathrm{dry} \text { tons }}{\mathrm{yr}}}=12,480 \frac{\text { gallons }}{\text { final dry tons }}$

\section{Polymer}

Polymer $=6 \mathrm{~g} / \mathrm{dry} \mathrm{kg}$ solids (Metcalf and Eddy 2014)

$$
\begin{array}{r}
\text { polymer }=\frac{6 \text { g polymer }}{\text { kg dry solids }} * \frac{1 \mathrm{~kg}}{2.2 \mathrm{lb}} * \frac{2,000 \mathrm{lb}}{1 \mathrm{ton}} \\
=5,454.5 \mathrm{~g} \text { polymer per ton of dry solids }
\end{array}
$$

$$
\begin{gathered}
\text { polymer }=\frac{5,454.5 \mathrm{~g} \text { polymer }}{1 \text { ton dry solids }} * \frac{1 \mathrm{~kg}}{1000 \mathrm{~g}} * \frac{2.2 \mathrm{lb}}{1 \mathrm{~kg}} * \frac{251 \text { ton dry solids }}{1 \mathrm{yr}} \\
=3015 \mathrm{lb} \text { polymer per year }
\end{gathered}
$$

$\frac{3015 \mathrm{lb} \text { polymer }}{\mathrm{yr}} * \frac{1 \mathrm{yr}}{200 \mathrm{dry} \text { tons }}=15 \mathrm{lb}$ polymer per dry ton

\section{Water for polymer dilution}


$0.5 \%$ dilution of polymer needed

$$
\begin{gathered}
\frac{\left(\frac{5454 \text { g polymer }}{\text { dry ton }}\right)}{\frac{0.5 \text { g polymer }}{100 \text { g water }} * \frac{1000 \mathrm{~g}}{1 \mathrm{~kg}} * \frac{1000 \mathrm{~kg}}{1 \mathrm{~m}^{3}} * \frac{1 \mathrm{~m}^{3}}{35.3 \mathrm{ft}^{3}} * \frac{1 \mathrm{ft}^{3}}{7.48 \mathrm{gal}}} * \frac{251 \text { dry tons }}{\mathrm{yr}} \\
* \frac{\mathrm{yr}}{200 \text { final dry tons }}=362 \text { gal water per dry ton solids }
\end{gathered}
$$

\section{Filtrate}

Filtrate (water removed from biosolids) calculated using a mass balance

(wet tons before BFP - wet tons after BFP) =

$$
\begin{aligned}
\left(\frac{5583 \text { tons }}{\mathrm{yr}}-\right. & \left.\frac{1142 \text { tons }}{\mathrm{yr}}\right) *\left(\frac{2,000 \mathrm{lb}}{1 \mathrm{ton}} * \frac{1 \mathrm{ft}^{3}}{62.4 \mathrm{lb}} * \frac{7.48 \mathrm{gal}}{1 \mathrm{ft}^{3}}\right) * \frac{1 \mathrm{yr}}{200 \text { final dry tons }} \\
& =5324 \frac{\mathrm{gal}}{\text { dry ton }}
\end{aligned}
$$

\section{Lagoon Storage}

\section{Diesel for dump truck to move biosolids from belt filter press to lagoons}

Given:

- Assumption $=2,000 \mathrm{ft}$ to air drying cell

- $\quad$ Dump truck fuel use $=3.2 \mathrm{mpg}$ (Jackson 2010)

- $\quad$ Dump truck size $=20$ cyd

- $\quad$ Quantity of biosolids $=1142$ tons

- $\quad$ Volume of biosolids $=47586 \mathrm{ft} 3$

- $\quad$ BFP runs 104 times per year

Quantity of biosolids per operational day $=\frac{1142 \text { wet tons }}{\mathrm{yr}} * \frac{1 \mathrm{yr}}{104 \text { times BFP is ran }}$

$$
=11 \frac{\text { wet tons }}{\text { operational day }}
$$


Volume of biosolids per operational day $=\frac{47586 \mathrm{ft}^{3}}{\mathrm{yr}} * \frac{1 \mathrm{yr}}{104 \text { times BFP is ran }}$

$$
=458 \frac{\mathrm{ft}^{3}}{\text { operational day }}=16.9 \mathrm{yd}^{3}
$$

Trips to and from pad $=\frac{\text { Volume of biosolids per run }}{\text { dump truck size }}=\frac{16.9 \text { cyd }}{20 \text { cyd }} \approx 1$

Total distance $=2 *$ trips to and from pad $*$ distance to pad $=2 * 1 * 2,000 \mathrm{ft}$

$$
=4,000 \mathrm{ft}
$$

Total distance $=\frac{4,000 \mathrm{ft}}{5,280 \frac{\mathrm{ft}}{\mathrm{mile}}}=0.76$ miles

Diesel Usage $=\frac{\text { total distance }}{\text { fuel use }}=\frac{1.52 \mathrm{miles}}{3.2 \mathrm{mpg}} * \frac{3.785 \mathrm{l}}{1 \mathrm{gal}}=0.90 \frac{\text { liters }}{\text { operational day }}$

Diesel usage $=0.90 \frac{\text { liters }}{\text { operational day }} * \frac{104 \text { opertional days }}{1 \mathrm{yr}}=93.19 \frac{\mathrm{L}}{\mathrm{yr}}$

Diesel per dry ton $=\frac{93.19 \frac{\text { liters }}{\mathrm{yr}}}{\frac{200 \text { final dry tons }}{\mathrm{yr}}}=0.47 \frac{\text { liters of diesel }}{\text { dry ton }}$

\section{Diesel for Front End loader Fuel to spread biosolids around lagoon}

Given:

- $\quad$ Bucket size $=3$ cyd

- Time to spread one load $=3$ minutes (low fuel burn - moving slow to prevent ripping liner) (Caterpiller 2012)

- $\quad$ Medium fuel burn mileage $=0.078$ liters/minute $($ Caterpiller 2012)

- Average distance of moving inside lagoon $=60 \mathrm{ft}$

- $\quad$ Biosolids volume per day $=16.9 \mathrm{cyd}$

Fuel needed $=$ time $*$ mileage $=3$ minutes $* \frac{0.078 \text { liters }}{\text { minute }}=0.24$ liters $/$ run

Runs per pressing $=\frac{\text { Volume }}{\text { bucket size }}=\frac{16.5 \text { cyd }}{3 \text { cyd }}=6$ runs 
Total fuel use per operational day $=0.24 \frac{\text { Liters }}{\text { run }} * 6$ runs $=1.41 \frac{\text { liters }}{\text { day }}$

Total fuel per year $=\frac{\text { total fuel }}{\text { operational day }} * \frac{\text { operational days }}{\text { year }}$

$$
=1.41 \text { liters } * 104 \frac{\text { operational days }}{\mathrm{yr}}=147 \frac{\text { liters }}{\mathrm{yr}}
$$

Diesel fuel per dry ton $=\frac{\text { Total fuel per year }}{\mathrm{FU}}=\frac{147 \text { liters }}{200 \frac{\text { dry ton }}{\mathrm{yr}}}$

$=0.73$ liters of diesel per dry ton

\section{Diesel for Front end loader to move from lagoon to air drying pad}

Given

- $\quad$ Bucket size $=3$ cyd

- $\quad$ Distance to drying cell $=500 \mathrm{ft}$

- $\quad$ Low fuel burn mileage $=0.078$ liters/minute (Caterpiller 2012)

- $\quad$ Medium fuel burn mileage $=0.12$ liters $/$ minute (Caterpiller 2012)

- Time spent removing biosolids from lagoon $=2$ months

- $\quad$ Weeks per 2 months $=8.7$

- 5 work days per week

- Quantity of biosolids $=625$ wet tons

- $\quad$ Volume of biosolids $=32715.7 \mathrm{ft} 3=1212$ cyd

- $\quad$ Distance to air drying pad $=500 \mathrm{ft}$

Biosolids per day $=\frac{\text { Volume of biosolids }}{\text { operational days }}=\frac{1212 \text { cyd }}{8.7 \text { weeks } * \frac{5 \text { days }}{1 \text { week }}}=28$ cyd

Time to scoop up biosolids in cell $=1$ minute (low fuel burn)

Time to drive to air drying cell @ $17 \mathrm{mph}=\frac{\text { distance }}{\text { rate }}=\frac{500 \mathrm{ft} * \frac{1 \mathrm{mile}}{5,280 \mathrm{ft}}}{17 \frac{\mathrm{miles}}{\mathrm{hr}} * \frac{1 \mathrm{hr}}{60 \mathrm{minutes}}}=0.3$ minutes (medium burn)

Dump biosolids and form windrows $=5$ minutes (low fuel burn)

Drive back to the lagoon $=0.3$ minutes (medium fuel burn) 
Total time@ medium fuel=0.7 minutes per run

Total time@low fuel=6 minutes

Fuel use at low $=U$ sage rate $*$ time $=\frac{0.078 \text { liters }}{\text { minute }} * 6 \frac{\text { minutes }}{\text { run }}=0.47 \frac{\text { liters }}{\text { run }}$

Fuel use at medium $=\frac{0.12 \text { liters }}{\text { minute }} * 0.7 \frac{\text { minute }}{\text { run }}=0.08 \frac{\text { liters }}{\text { run }}$

Runs per day $\frac{28 \frac{\text { cyd }}{\text { day }}}{3 \text { cyd }}=10$ runs

Fuel per day $=\frac{\text { runs }}{\text { day }} * \frac{\text { fuel }}{\text { run }}=\frac{5 \text { runs }}{\text { day }} *\left(\frac{0.47 \text { liters }}{\text { run }}+\frac{0.08 \text { liters }}{\text { run }}\right)=5.50 \frac{\text { liters }}{\text { day }}$

Total liters $=$ liters used per day $*$ operational days $=5.5 \frac{\text { liters }}{\text { day }} * 8.7 \frac{\text { weeks }}{\text { duration }} *$ $5 \frac{\text { work days }}{\text { week }}=239 \frac{\text { liters }}{\mathrm{yr}}$

Liters per dry ton $=\frac{\text { total liters }}{\mathrm{FU}}=\frac{239 \frac{\mathrm{liters}}{\mathrm{yr}}}{200 \frac{\mathrm{dry} \text { ton }}{\mathrm{yr}}}=1.2 \frac{\text { liters }}{\text { dry ton }}$

\section{Lagoon Sizing}

Given:

- Assume L=W

- $\quad$ Quantity of biosolids $=1142$ wet tons

- $\quad$ Volume of biosolids $=47586 \mathrm{ft} 3=1762 \mathrm{yd} 3$

- Depth of sludge $=5 \mathrm{ft}$

- $\quad$ Side slope $=4$

- $\quad$ Clay depth $=0.5 \mathrm{ft}$

- $\quad$ Freeboard $=2 \mathrm{ft}$

Length \& Width @ 5ft deep =

Volume $=\frac{\text { depth }}{6}\left(A_{\text {top }}+A_{\text {bottom }}+4 A_{\text {mid }}\right)$

$\mathrm{A}_{\text {top }}=\mathrm{L} * \mathrm{~W}=\mathrm{L}^{2}$

$\mathrm{A}_{\text {bottom }}=(\mathrm{L}-2 \mathrm{Sd})(\mathrm{W}-2 \mathrm{Sd})=(\mathrm{L}-2 \mathrm{Sd})(\mathrm{L}-2 \mathrm{Sd})$ 
$A_{\text {mid }}=(L-S d)(W-S d)=(L-S d)(L-S d)$

$47,586 \mathrm{ft}^{3}=\frac{5 \mathrm{ft}}{6} *\left(\mathrm{~L}^{2}+(\mathrm{L}-2 * 4 * 5 \mathrm{ft})(\mathrm{L}-2 * 4 * 5 \mathrm{ft})\right.$

$$
+4[(\mathrm{~L}-4 * 5 \mathrm{ft})(\mathrm{L}-4 * 5 \mathrm{ft})]
$$

$\mathrm{L}=117 \mathrm{ft}$

Add $0.5 \mathrm{ft}$ of clay (add 4' to length and width)

$\mathrm{L}=\mathrm{W}=121 \mathrm{ft}$

Volume with clay $(\mathrm{d}=5.5 \mathrm{ft})$

$$
\begin{aligned}
& =\left(\frac{5.5 \mathrm{ft}}{6}\right) *\left(121^{2}+(121-2 * 4 * 5.5 \mathrm{ft})(121-2 * 4 * 5.5 \mathrm{ft})\right. \\
& +4[(121-4 * 5.5 \mathrm{ft})(121-4 * 5.5 \mathrm{ft})]=54,793 \mathrm{ft}^{3}=2029 \mathrm{yd}^{3}
\end{aligned}
$$

Volume of clay $=2,029 \mathrm{yd}^{3}-1,762 \mathrm{yd}^{3}=267 \mathrm{yd}^{3}$

Volume of clay before shrinkage $=\frac{267 \mathrm{yd}^{3}}{0.85}=314 \mathrm{yd}^{3}$

Amount of freeboard $=2 \mathrm{ft}$

Length with freeboard $=121+(2 \mathrm{ft} * 4) * 2=137 \mathrm{ft}$

Volume with freeboard $(\mathrm{d}=7.5 \mathrm{ft})=\left(\frac{7.5 \mathrm{ft}}{6}\right) *\left(137^{2}+(137-2 * 4 * 7.5 \mathrm{ft})(137-2 *\right.$

$4 * 7.5 \mathrm{ft})+4[(137-4 * 7.5 \mathrm{ft})(137-4 * 7.5 \mathrm{ft})]=88,118 \mathrm{ft}^{3}=3,264 \mathrm{yd}^{3}$

Volume of soils hauled (Or used for berms on site) $=3,264 \mathrm{yd}^{3} * 1.25=4,080 \mathrm{yd}^{3}$

Liner

Area of bottom $=(\mathrm{L}-2 \mathrm{Sd})(\mathrm{L}-2 \mathrm{Sd})=(137 \mathrm{ft}-2 * 4 * 7.5 \mathrm{ft})(137 \mathrm{ft}-2 * 4 *$ $7.5 \mathrm{ft})=5,929 \mathrm{ft}^{2}$ 
$\sqrt{5929 \mathrm{ft}^{2}}=77 \mathrm{ft}$

Width of slope sides $=137 \mathrm{ft}-77 \mathrm{ft}=\frac{60 \mathrm{ft}}{2}=30 \mathrm{ft}$

Angle $=\tan ^{-1}\left(\frac{30}{7.5}\right)=76^{\circ}$

Actual width $=\mathrm{W}=\frac{30 \mathrm{ft}}{\sin \left(76^{\circ}\right)}=30.9 \mathrm{ft}$

Slope side areas - corners $=4 *(30.9 \mathrm{ft} * 77 \mathrm{ft})=9,517.2 \mathrm{ft}^{2}$

Area 1 corner $=2 *\left(\frac{1}{2} * 30.9 \mathrm{ft} * 30.9 \mathrm{ft}\right)=955 \mathrm{ft}^{2}$

Area of 4 corners $=955 \mathrm{ft}^{2} * 4=3,820 \mathrm{ft}^{2}$

Total area of liner $=5,929 \mathrm{ft}^{2}+9,517.2 \mathrm{ft}^{2}+3,820 \mathrm{ft}^{2}=19,266 \mathrm{ft}^{2}=2,140.7 \mathrm{yd}^{2}$

Volume of clay for 4 lagoons $=314 \mathrm{yd}^{3} * 4=1,256 \mathrm{yd}^{3}$

Area of liner for 4 lagoons $=2140.7 \mathrm{yd}^{2} * 4=8563 \mathrm{yd}^{2}$

Volume of soils hauled for 4 lagoons $=4080 \mathrm{yd}^{3} * 4=16318 \mathrm{yd}^{3}$

Lifetime of lagoon $=30$ years

Clay per dry ton $=\frac{1,256 \mathrm{yd}^{3}}{30 \text { years }} * \frac{\mathrm{yr}}{200 \text { dry ton }}=0.209 \frac{\mathrm{yd}^{3}}{\text { dry ton }}$

Liner per dry ton $=\frac{8563 \mathrm{yd}^{2}}{30 \text { years }} * \frac{\mathrm{yr}}{200 \text { dry ton }}=1.43 \frac{\mathrm{yd}^{2}}{\text { dry ton }}$

\section{Emissions}

Given:

- Methane global warming potential $=28$ (Myhre, Shindell et al. 2013) 
- Dinitrogen Monoxide global warming potential = 256 (Myhre, Shindell et al. 2013)

Middle age lagoon emissions (1-3 years old)

Accounting for $2^{\text {nd }}$ year of storage plus 3 months from the $1^{\text {st }}$ year and 1 month which accounts for 2 months of removal

Total month accounted for $=16$ months

$\mathrm{CO} 2=30.5 \mathrm{~kg} \mathrm{CO} 2 \mathrm{eq} / \mathrm{Mg}$ yr (Majumder, Livesley et al. 2014)

$251 \frac{\text { dry tons }}{\mathrm{yr}} * \frac{2000 \mathrm{lb}}{1 \mathrm{ton}} * \frac{1 \mathrm{~kg}}{2.2 \mathrm{lb}} * \frac{1 \mathrm{Mg}}{1000 \mathrm{~kg}}=228 \frac{\mathrm{dry} \mathrm{Mg}}{\mathrm{yr}}$

$\frac{30.5 \mathrm{~kg} \mathrm{CO} 2 \mathrm{eq}}{\mathrm{Mg} \mathrm{yr}} * \frac{228 \mathrm{Mg}}{\mathrm{yr}} * \frac{16 \text { months }}{12 \frac{\mathrm{months}}{\mathrm{yr}}}=9,289 \frac{\mathrm{kg} \mathrm{CO} 2 \mathrm{eq}}{\mathrm{yr}}$

$\mathrm{CH} 4=2 \mathrm{~kg} \mathrm{CO} 2 \mathrm{eq} / \mathrm{Mg}$ yr (Majumder, Livesley et al. 2014)

$\frac{2 \mathrm{~kg} \mathrm{CO} 2 \mathrm{eq}}{\mathrm{Mg} \mathrm{yr}} * \frac{228 \mathrm{Mg}}{\mathrm{yr}} * \frac{16 \text { months }}{12 \frac{\mathrm{months}}{\mathrm{yr}}}=609 \frac{\mathrm{kg} \mathrm{CO} 2 \mathrm{eq}}{\mathrm{yr}}$

$\mathrm{N} 2 \mathrm{O}=26.8 \mathrm{~kg} \mathrm{CO} 2$ eq $/ \mathrm{Mg}$ yr (Majumder, Livesley et al. 2014)

$\frac{26.8 \mathrm{~kg} \mathrm{CO} 2 \mathrm{eq}}{\mathrm{Mg} \mathrm{yr}} * \frac{228 \mathrm{Mg}}{\mathrm{yr}} * \frac{16 \text { months }}{12 \frac{\mathrm{months}}{\mathrm{yr}}}=8,162 \frac{\mathrm{kg} \mathrm{CO} 2 \mathrm{eq}}{\mathrm{yr}}$

Young lagoon emissions ( $<1$ yr old $)$

Accounts for 3 months of filling ( 6 months total) plus the first nine months of storage

$\mathrm{CO} 2=30.1 \mathrm{~kg} \mathrm{CO} 2$ eq $/$ dry Mg yr (Majumder, Livesley et al. 2014)

$\frac{30.1 \mathrm{~kg} \mathrm{CO} 2 \mathrm{eq}}{\mathrm{Mg} \mathrm{yr}} * \frac{228 \mathrm{Mg}}{\mathrm{yr}}=6,875 \frac{\mathrm{kg} \mathrm{CO} 2 \mathrm{eq}}{\mathrm{yr}}$

$\mathrm{CH} 4=0.2 \mathrm{~kg} \mathrm{CO} 2$ eq $/$ dry Mg yr (Majumder, Livesley et al. 2014)

$\frac{0.2 \mathrm{~kg} \mathrm{CO} 2 \mathrm{eq}}{\mathrm{Mg} \mathrm{yr}} * \frac{228 \mathrm{Mg}}{\mathrm{yr}}=46 \frac{\mathrm{kg} \mathrm{CO} 2 \mathrm{eq}}{\mathrm{yr}}$

$\mathrm{N} 2 \mathrm{O}=60 \mathrm{~kg} \mathrm{CO} 2$ eq $/$ dry Mg yr (Majumder, Livesley et al. 2014) 
$\frac{60 \mathrm{~kg} \mathrm{CO} 2 \mathrm{eq}}{\mathrm{Mg} \mathrm{yr}} * \frac{228 \mathrm{Mg}}{\mathrm{yr}}=13,705 \frac{\mathrm{kg} \mathrm{CO} 2 \mathrm{eq}}{\mathrm{yr}}$

Total Emissions

$$
\begin{aligned}
\mathrm{CO}_{2, \text { total }}=9,289 \frac{\mathrm{kg} \mathrm{CO} 2 \mathrm{eq}}{\mathrm{yr}}+6,875 \frac{\mathrm{kg} \mathrm{CO} 2 \mathrm{eq}}{\mathrm{yr}}=16,164 \mathrm{~kg} \mathrm{CO} 2 \\
\mathrm{CO}_{2, \text { total as C }}=\frac{16,164 \mathrm{~kg} \mathrm{CO} 2}{\mathrm{yr}} * \frac{1 \mathrm{kmol} \mathrm{CO} 2}{44 \mathrm{~kg}} * \frac{1 \mathrm{kmol} \mathrm{C}}{1 \mathrm{kmol} \mathrm{CO} 2} * \frac{12.01 \mathrm{~kg}}{1 \mathrm{kmol} \mathrm{C}} \\
=4,412 \mathrm{~kg} \mathrm{C} \text { as CO2 }
\end{aligned}
$$

$\mathrm{CH}_{4, \text { total }}=\left(609 \frac{\mathrm{kg} \mathrm{CO} 2 \mathrm{eq}}{\mathrm{yr}}+46 \frac{\mathrm{kg} \mathrm{CO} 2 \mathrm{eq}}{\mathrm{yr}}\right) * \frac{1}{28 \mathrm{GWP}}=23 \mathrm{~kg} \mathrm{CH} 4$

$\mathrm{CH}_{4, \text { total as } \mathrm{C}}=\frac{23 \mathrm{~kg} \mathrm{CH} 4}{\mathrm{yr}} * \frac{1 \mathrm{kmol} \mathrm{CH} 4}{16 \mathrm{~kg}} * \frac{1 \mathrm{kmol} \mathrm{C}}{1 \mathrm{kmol} \mathrm{CH} 4} * \frac{12.01 \mathrm{~kg}}{1 \mathrm{kmol} \mathrm{C}}=18 \mathrm{~kg} \mathrm{C}$ as CH 4

Total Carbon loss $=4,412 \mathrm{~kg}$ Cas CO2 $+18 \mathrm{~kg} \mathrm{C}$ as $\mathrm{CH} 4=4,430 \mathrm{~kg} \mathrm{C}$

$\mathrm{N}_{2} \mathrm{O}_{\text {total }}=\left(8,162 \frac{\mathrm{kg} \mathrm{CO} 2 \mathrm{eq}}{\mathrm{yr}}+13,705 \frac{\mathrm{kg} \mathrm{CO} 2 \mathrm{eq}}{\mathrm{yr}}\right) * \frac{1}{265 \mathrm{GWP}}=83 \mathrm{~kg} \mathrm{~N} 20$

$\mathrm{N}_{2} \mathrm{O}_{\text {total as } \mathrm{N}}=\frac{83 \mathrm{~kg} \mathrm{~N} 2 \mathrm{O}}{\mathrm{yr}} * \frac{1 \mathrm{kmol} \mathrm{N} 20}{44 \mathrm{~kg} \mathrm{~N} 2 \mathrm{O}} * \frac{2 \mathrm{kmol} \mathrm{N}}{1 \mathrm{kmol} \mathrm{N} 20} * \frac{14 \mathrm{~kg} \mathrm{~N}}{1 \mathrm{kmol} \mathrm{N}}=53 \mathrm{~kg} \mathrm{~N}$ as N2O

Air Drying

\section{Air drying sizing}

Given:

- Windrow height $=2 \mathrm{ft}$

- Windrow width $=7 \mathrm{ft}$

- Clearance width $=5 \mathrm{ft}$

- Duration of air cycle $=10$ weeks

- Mixing once a week

- $\quad$ Number of windrows $=17$

- Volume of biosolids $=32716 \mathrm{ft} 3$

- Quantity of biosolids $=625$ tons

Width of windrow + clearance $=5 \mathrm{ft}+7 \mathrm{ft}=12 \mathrm{ft}$ 
Cross Section of windrow $=\frac{1}{2}$ base $*$ height $=0.5 * 7 \mathrm{ft} * 2 \mathrm{ft}=7 \mathrm{ft}^{2}$

Length of pad $=\frac{\text { Sludge volume @ 32\% per cycle }}{\text { cross section of windrow } * \text { number of windrow rows }}=\frac{32716 \mathrm{ft}^{3}}{7 \mathrm{ft}^{2} * 17}$ $=275 \mathrm{ft}$

Length of pad with $7^{\prime}$ clearance at each end $=275 \mathrm{ft}+14 \mathrm{ft}=289 \mathrm{ft}$

Width of Pad with clearance $=5 \mathrm{ft}+12 \mathrm{ft} * 17=209 \mathrm{ft}$

Assumption: Air drying pad has $0.5 \mathrm{ft}$ asphalt. Lifetime of pad is 25 years.

Tonnage of asphalt and gravel calculated using an online calculator with dimensions and compaction.

Asphalt $=2215$ tons $($ CAPA 2019)

Dry ton of biosolids per lifetime $=\mathrm{FU} *$ lifetime $=\frac{200 \text { dry tons }}{\text { year }} * 25 \mathrm{yr}$

$$
=5,000 \text { dry tons }
$$

Ashpalt per dry ton $=\frac{2215 \text { ton asphalt }}{5,000 \text { dry tons } / \text { lifetime }}=0.44 \frac{\text { tons asphalt }}{\text { dry ton }}$

\section{Diesel for turning windrows}

Given: $0.1 \mathrm{~L}$ diesel per ton (Komilis and Ham 2004). This assumes turning once a week for 4 weeks

$\frac{0.1 \mathrm{~L}}{\text { ton } * 4 \text { weeks }} * 10$ weeks $=0.25 \frac{\mathrm{L}}{\text { ton }}$

$\frac{0.25 \mathrm{~L}}{\text { ton }} * \frac{625 \text { tons at start of air drying }}{1 \mathrm{yr}} * \frac{1 \mathrm{yr}}{200 \text { dry tons }}=0.78 \mathrm{~L}$ diesel per dry ton

\section{Emissions}

Given

- $\quad \mathrm{C} / \mathrm{N}$ ratio before lagoon $=15.6($ Seagren 2019$)$

- $\quad \% \mathrm{~N}=1.88$ (Seagren 2019) 
$\% \mathrm{C}=\frac{1.88}{100} * 15.6 * 100=29.3 \%$

Carbon content before lagoon $=\left(\frac{\% \mathrm{C}}{100}\right) *$ dry wt $=\frac{29.3}{100} * 251 \frac{\text { dry ton }}{\mathrm{yr}}=73.7 \frac{\text { ton C }}{\mathrm{yr}}$

Nitrogen Content $=\left(\frac{\% \mathrm{~N}}{100}\right) * \mathrm{dry} \mathrm{wt}=\left(\frac{1.88}{100}\right) * 251 \frac{\text { dry ton }}{\mathrm{yr}}=4.7 \frac{\text { ton } \mathrm{N}}{\mathrm{yr}}$

Carbon loss in lagoons $=4430 \mathrm{~kg} \mathrm{C} * \frac{2.2 \mathrm{lb}}{1 \mathrm{~kg}} * \frac{1 \text { ton }}{2000 \mathrm{lb}}=4.9$ tons $\mathrm{C}$

Nitrogen loss in lagoons as $\mathrm{N} 2 \mathrm{O}=53 \mathrm{~kg} \mathrm{~N} * \frac{2.2 \mathrm{lb}}{\mathrm{lkg}} * \frac{1 \text { ton }}{2000 \mathrm{lb}}=0.06$ tons $\mathrm{C}$

Carbon content after lagoon $=73.7$ ton $\mathrm{C}-4.7$ ton $\mathrm{C}=68.8$ ton $\mathrm{C}$

Nitrogen content after lagoon $=4.7$ tons $\mathrm{N}-0.06$ tons $\mathrm{N}=4.7$ tons $\mathrm{N}$

Methane loss $=3.8 \%$ of initial carbon (Yamulki 2006)

$\mathrm{N} 2 \mathrm{O}$ loss $=0.87 \%$ of initial nitrogen (Yamulki 2006)

The air drying emissions sensitivity analysis was also conducted in lagoon storage. See the air drying section for calculations.

Total carbon loss $=57 \%$ (Tiquia, Richard et al. 2002)

$\mathrm{N} 2 \mathrm{O}$ released $=$ initial $\mathrm{N}$ dry $\mathrm{wt} . * \% \mathrm{~N}$ loss $=\frac{4.67 \mathrm{ton} \mathrm{N}}{\mathrm{yr}} * \frac{0.87}{100}=0.041 \frac{\text { ton } \mathrm{N} 2 \mathrm{O} \text { as } \mathrm{N}}{\mathrm{yr}}$

$\mathrm{N} 2 \mathrm{O}$ released per dry ton $=\frac{0.041 \text { ton } \mathrm{N} \text { as N2O }}{\mathrm{yr}} * \frac{2000 \mathrm{lb}}{1 \mathrm{ton}} * \frac{1 \mathrm{~kg}}{2.2 \mathrm{lb}} * \frac{1 \mathrm{kmol} \mathrm{N}}{14 \mathrm{~kg}} * \frac{1 \mathrm{kmol} \mathrm{N} 2 \mathrm{O}}{2 \mathrm{kmol} \mathrm{N}} *$ $\frac{44 \mathrm{~kg} \mathrm{~N} 2 \mathrm{O}}{1 \mathrm{kmol} \mathrm{N} 2 \mathrm{O}}=58 \frac{\mathrm{kg} \mathrm{N} 2 \mathrm{O}}{\mathrm{yr}}$

$\mathrm{CH} 4$ released $=$ inital C dry wt. $* \%$ C loss $=\frac{68.8 \text { ton C }}{\mathrm{yr}} * \frac{3.8}{100}=2.615 \frac{\text { ton } \mathrm{CH} 4 \text { as C }}{\mathrm{yr}}$ $\mathrm{CH} 4$ released $=2.615 \frac{\text { ton } \mathrm{C} \text { as } \mathrm{CH} 4}{\mathrm{yr}} * \frac{2000 \mathrm{lb}}{1 \mathrm{ton}} * \frac{1 \mathrm{~kg}}{2.2 \mathrm{lb}} * \frac{1 \mathrm{kmol} \mathrm{C}}{12.01 \mathrm{~kg} \mathrm{C}} * \frac{1 \mathrm{kmol} \mathrm{CH} 4}{1 \mathrm{kmol} \mathrm{C}}$ $* \frac{16 \mathrm{~kg} \mathrm{CH} 4}{1 \mathrm{kmol} \mathrm{CH} 4}=3167 \frac{\mathrm{kg} \mathrm{CH} 4}{\mathrm{yr}}$ 
Total Carbon loss $=$ Carbon content $* \%$ Carbon loss $=68.8 \frac{\operatorname{ton} \mathrm{C}}{\mathrm{yr}} *\left(\frac{57}{100}\right)=39.2 \frac{\text { ton } \mathrm{C}}{\mathrm{yr}}$

Carbon dioxide released $=$ total $\mathrm{C}$ released $-\mathrm{C}$ released as $\mathrm{CH} 4=39.2 \frac{\operatorname{ton} \mathrm{C}}{\mathrm{yr}}-$

$2.615 \frac{\text { ton } \mathrm{C} \text { as } \mathrm{CH} 4}{\mathrm{yr}}=36.61 \frac{\text { ton } \mathrm{C} \text { as } \mathrm{CO} 2}{\mathrm{yr}}$

$\mathrm{CO} 2$ released $=36.61 \frac{\text { ton } \mathrm{C} \text { as } \mathrm{CO} 2}{\mathrm{yr}} * \frac{2000 \mathrm{lb}}{1 \mathrm{ton}} * \frac{1 \mathrm{~kg}}{2.2 \mathrm{lb}} * \frac{1 \mathrm{kmol} \mathrm{C}}{12.01 \mathrm{~kg} \mathrm{C}} * \frac{1 \mathrm{kmol} \mathrm{CO} 2}{1 \mathrm{kmol} \mathrm{C}}$

$$
* \frac{44 \mathrm{~kg} \mathrm{CO} 2}{1 \mathrm{kmol} \mathrm{CO} 2}=121,931 \mathrm{~kg} \frac{\mathrm{CO} 2}{\mathrm{yr}}
$$

$\mathrm{CO} 2$ released per dry ton $(\mathrm{AD})=121,931 \mathrm{~kg} \frac{\mathrm{CO} 2}{\mathrm{yr}} * \frac{1 \mathrm{yr}}{200 \text { final dry tons }}=609.7 \frac{\mathrm{kg} \mathrm{CO} 2}{\text { final dry ton }}$

$\mathrm{CH} 4$ released per dry ton $(\mathrm{AD})=3167 \frac{\mathrm{kg} \mathrm{CH} 4}{\mathrm{yr}} * \frac{1 \mathrm{yr}}{200 \text { final dry tons }} 15.8 \frac{\mathrm{kg} \mathrm{CH} 4}{\text { final dry ton }}$

$\mathrm{N} 2 \mathrm{O}$ released per dry ton $(\mathrm{AD})=58.3 \frac{\mathrm{kg} \mathrm{N} 20}{\mathrm{yr}} * \frac{1 \mathrm{yr}}{200 \text { final dry tons }} 0.292 \frac{\mathrm{kg} \mathrm{N} 2 \mathrm{O}}{\text { final dry ton }}$

$\mathrm{N} 2 \mathrm{O}$ released per dry ton (Poulsen and Hansen) $=\frac{83 \mathrm{~kg} \mathrm{~N} 20}{200 \frac{\mathrm{dry} \text { ton }}{\mathrm{yr}}}=0.413 \mathrm{~kg} \mathrm{~N} 20$ per year

$\mathrm{CH} 4$ released per dry ton (Poulsen and Hansen) $=\frac{23 \mathrm{~kg} \mathrm{CH} 4}{200 \frac{\text { dry ton }}{\mathrm{yr}}}=0.12 \mathrm{~kg} \mathrm{CH} 4$ per year

$\mathrm{CO} 2$ released per dry ton (Poulsen and Hansen) $=\frac{16,164}{200 \frac{\mathrm{dry} \text { ton }}{\mathrm{yr}}}=840.8 \mathrm{~kg}$ CO2 per year

\section{$\underline{\text { Transportation }}$}

Distance $=50$ miles $=80$ kilometers

Quantity of biosolids $=\frac{333 \text { wet tons }}{\mathrm{yr}} * \frac{1 \text { tonne }}{1.10231 \text { ton }}=302 \frac{\text { tonnes }}{\mathrm{yr}}$

Mass Traveled $=\frac{302 \text { tonnes }}{\mathrm{yr}} * 80$ kilometers $=24,332 \mathrm{tkm}$ per year 
Size of truck $=20$ cyd

Volume $=\frac{15,972 \mathrm{ft}^{3}}{\mathrm{yr}} * \frac{1 \mathrm{cyd}}{27 \mathrm{ft}^{3}}=592 \frac{\mathrm{cyd}}{\mathrm{yr}}$

Weighted trucks $=\frac{592 \frac{\mathrm{cyd}}{\mathrm{yr}}}{20 \mathrm{cyd}}=30$ trips

\section{A.3 Composting Calculations}

Mechanical Dewatering

\section{Electricity}

EPA belt filter press electricity usage algorithm

$\mathrm{E}=\left[-5.42\left(\mathrm{TBFW}^{3}\right)+234.6\left(\mathrm{TBFW}^{2}\right)+16,020(\mathrm{TBFW})+13,997\right]($ USEPA 1985)

Where:

- $\quad \mathrm{E}=$ Annual electrical energy required $(\mathrm{kWhr} / \mathrm{yr}) * *$

- $\quad$ TBFW $=$ Total belt filter width (m)

**assumes $8 \mathrm{hr}$ work days for 365 operational days/yr

$E=[-5.42(1 m)+234.6(1 m)+16,020(1 m)+13,997=30,246 \mathrm{kWh} / \mathrm{yr}$

Daily electricity use $=30,246 \frac{\mathrm{kWh}}{\mathrm{yr}} * \frac{1 \mathrm{yr}}{365 \text { days }}=82.9 \mathrm{kWh} /$ day

Electricity Use per $\mathrm{FU}=\frac{82.9 \mathrm{kWh}}{\text { day }} * \frac{2 \text { operational day }}{\text { week }} * \frac{52 \text { week }}{1 \mathrm{yr}} * \frac{1 \mathrm{yr}}{200 \text { dry ton }}$

$$
=43.1 \frac{\mathrm{kWh}}{\text { dry ton }}
$$

\section{Belt Filter Press sizing}

Given

- Loading rate $=700$ dry lbs per hour per meter of width (Metcalf and Eddy 2014)

- Work week $=2$ day per week

- Work day $=8 \mathrm{hrs} /$ day 
Daily rate (dry) $=$ Weight of dry solids $* \frac{2,000 \mathrm{lb}}{1 \text { ton }} * \frac{1 \mathrm{yr}}{365 \text { days }}$

$$
=\frac{235 \text { dry ton }}{\text { year }} * \frac{2,000 \mathrm{lb}}{1 \text { ton }} * \frac{1 \mathrm{yr}}{365 \text { days }}=1,287.7 \frac{\mathrm{lb}}{\text { day }}
$$

Operational daily rate $($ dry $)=$ daily rate $* \frac{7 \text { days }}{1 \text { week }} * \frac{1 \text { week }}{2 \text { operational days }}$

$$
=\frac{1,287.7 \mathrm{lb}}{\text { day }} * \frac{7 \text { days }}{\text { week }} * \frac{1 \text { week }}{2 \text { operational day }}=4,506.8 \frac{\mathrm{lb}}{\text { operational day }}
$$

Hourly rate $=\frac{\text { operational daily rate (dry) }}{\text { hours per work day }}=\frac{\frac{4,506.8 \mathrm{lb}}{\text { operational day }}}{\frac{8 \text { hours }}{\text { operational day }}}=564 \frac{\mathrm{lb}}{\mathrm{hr}}$

Belt Width $=\frac{\text { hourly rate }}{\text { loading rate }}=\frac{564 \frac{\mathrm{lb}}{\mathrm{hr}}}{700 \frac{\mathrm{lb}}{\mathrm{hr} \mathrm{m}}}=0.81 \mathrm{~m}$

Round up to the next commercially available size $=1.0 \mathrm{~m}$

\section{Wash water}

Wash water needed $=50$ gallons per minute per meter of belt width (Metcalf and Eddy 2014)

Wash water needed $=\frac{50 \text { gal }}{\text { minute }} * \frac{60 \text { minutes }}{1 \mathrm{hr}} * \frac{8 \text { hours }}{1 \text { work day }} * \frac{104 \text { work days }}{1 \mathrm{yr}}$

$$
=2,496,000 \frac{\text { gallons }}{\text { year }}
$$

Wash water needed $=\frac{\frac{2,496,000 \text { gallons }}{\text { year }}}{\frac{200 \text { dry tons }}{\mathrm{yr}}}=12,480 \frac{\text { gallons }}{\text { final dry tons }}$

\section{Polymer}

Polymer $=6 \mathrm{~g} / \mathrm{dry}$ kg solids (Metcalf and Eddy 2014)

$$
\begin{gathered}
\text { polymer }=\frac{6 \text { g polymer }}{\text { kg dry solids }} * \frac{1 \mathrm{~kg}}{2.2 \mathrm{lb}} * \frac{2,000 \mathrm{lb}}{1 \mathrm{ton}} \\
=5,454.5 \mathrm{~g} \text { polymer per ton of dry solids }
\end{gathered}
$$




$$
\begin{aligned}
\text { polymer }= & \frac{5,454.5 \mathrm{~g} \text { polymer }}{1 \text { ton dry solids }} * \frac{1 \mathrm{~kg}}{1000 \mathrm{~g}} * \frac{2.2 \mathrm{lb}}{1 \mathrm{~kg}} * \frac{235 \text { ton dry solids }}{1 \mathrm{yr}} \\
& =2824 \mathrm{lb} \text { polymer per year }
\end{aligned}
$$

$\frac{2824 \mathrm{lb} \text { polymer }}{\mathrm{yr}} * \frac{1 \mathrm{yr}}{200 \mathrm{dry} \text { tons }}=14 \mathrm{lb}$ polymer per dry ton

\section{Water for polymer dilution}

$0.5 \%$ dilution of polymer needed

$$
\begin{gathered}
\frac{\left(\frac{5454 \text { g polymer }}{\text { dry ton }}\right)}{\frac{0.5 \text { g polymer }}{100 \text { g water }} * \frac{1000 \mathrm{~g}}{1 \mathrm{~kg}} * \frac{1000 \mathrm{~kg}}{1 \mathrm{~m}^{3}} * \frac{1 \mathrm{~m}^{3}}{35.3 \mathrm{ft}^{3}} * \frac{1 \mathrm{ft}^{3}}{7.48 \mathrm{gal}}} * \frac{235 \mathrm{dry} \text { tons }}{\mathrm{yr}} \\
* \frac{\mathrm{yr}}{200 \text { final dry tons }}=339 \text { gal water per dry ton solids }
\end{gathered}
$$

\section{Filtrate}

Filtrate (water removed from biosolids) calculated using a mass balance (wet tons before BFP - wet tons after BFP) =

$$
\left(\frac{5229 \text { tons }}{\mathrm{yr}}-\frac{1070 \text { tons }}{\mathrm{yr}}\right) *\left(\frac{2,000 \mathrm{lb}}{1 \mathrm{ton}} * \frac{1 \mathrm{ft}^{3}}{62.4 \mathrm{lb}} * \frac{7.48 \mathrm{gal}}{1 \mathrm{ft}^{3}}\right)=4986 \frac{\text { gal }}{\text { dry ton }}
$$

\section{Composting}

1. Diesel fuel for dump truck transportation from BFP to composting pad

\section{Dump truck fuel}

Given

- Assumption $=2,000 \mathrm{ft}$ to air drying cell

- $\quad$ Dump truck fuel use $=3.2 \mathrm{mpg}$ (Jackson 2010)

- Dump truck size $=20$ cyd

- Total quantity of biosolids $=1,070$ tons/yr (see TS \& VS tab)

- Total volume of biosolids $=44,563 \mathrm{ft} 3$ (see TS \& VS tab)

- Belt filter runs 104 days per year

Quantity of biosolids per operational day $=\frac{1070 \frac{\mathrm{tons}}{\mathrm{yr}}}{104 \frac{\mathrm{runs}}{\mathrm{yr}}}=10.3 \frac{\text { tons }}{\mathrm{run}}$ 
Volume of biosolids per operational day $=\frac{44,563 \frac{\mathrm{ft} 3}{\mathrm{yr}}}{104 \frac{\mathrm{runs}}{\mathrm{yr}}}=428.5 \frac{\mathrm{ft} 3}{\mathrm{run}}$

Volume of biosolids per operational day $=428.5 \frac{\mathrm{ft} 3}{\text { run }} * \frac{1 \mathrm{yd}^{3}}{27 \mathrm{ft}^{3}}=16 \frac{\mathrm{yd}^{3}}{\text { run }}$

Trip to and from pad $=\frac{\text { Volume of biosolids per run }}{\text { dump truck size }}=\frac{16 \text { cyd }}{20 \text { cyd }} \approx 1$

Total distance $=2 *$ trips to and from pad $*$ distance to pad $=2 * 1 * 2,000 \mathrm{ft}$ $=4,000 \mathrm{ft}$

Total distance $=\frac{4,000 \mathrm{ft}}{5,280 \frac{\mathrm{ft}}{\mathrm{mile}}}=0.76$ miles

Diesel Usage $=\frac{\text { total distance }}{\text { fuel use }}=\frac{1.52 \text { miles }}{3.2 \mathrm{mpg}} * \frac{3.785 \mathrm{l}}{1 \mathrm{gal}}=0.9 \frac{\text { liters }}{\text { operational day }}$

diesel usage per year $=\frac{0.9 \text { liters }}{\text { operational day }} * \frac{104 \text { operational days }}{1 \mathrm{yr}}=93.6 \frac{\text { liters }}{\mathrm{yr}}$

Diesel per dry ton $=\frac{93.6 \frac{\text { liters }}{\mathrm{yr}}}{\frac{200 \text { final dry tons }}{\mathrm{yr}}}=0.47 \frac{\text { liters of diesel }}{\text { dry ton }}$

\section{Windrow composting amendments}

Given:

- Woodchips (structural amendment)

- $\quad$ Recycling efficiency of woodchips $=70 \%$ (Spellman 1997)

- $\quad$ New woodchips $=30 \% ; 500 \mathrm{lb} / \mathrm{yd} 3$ (Spellman 1997)

- $\quad$ Recycled woodchips $=70 \% ; 750 \mathrm{lb} / \mathrm{yd} 3$ (Spellman 1997)

- Woodchip: sludge volume ratio = 2:1 (Wang, Shammas et al. 2007)

- $\quad$ Bulk density $=48 \mathrm{lb} / \mathrm{ft} 3$

- $\quad$ Volume of biosolids $=44,563 \mathrm{ft} 3$ (VS \& TS tab)

- Quantity of biosolids $=1,070$ tons (TS \& VS tab)

- 3 cycles (21 compost, 30 day cure) in summer

Volume of biosolids $=44563 \mathrm{ft}^{3} * \frac{1 \mathrm{yd}^{3}}{27 \mathrm{ft}^{3}}=1650.5 \mathrm{yd}^{3}$ 
Volume of woodchips $=2 *$ biosolids volume $=2 * 1,650.5 \frac{\mathrm{yd}^{3}}{\mathrm{yr}}=3301 \frac{\mathrm{yd}^{3}}{\mathrm{yr}}$

Woodchips per dry ton $=\frac{\text { volume of woodchips }}{\mathrm{FU}}=\frac{3301 \frac{\mathrm{yd}^{3}}{\mathrm{yr}}}{200 \frac{\mathrm{dry} \text { ton }}{\mathrm{yr}}}=16.5 \frac{\mathrm{yd}^{3}}{\mathrm{dry} \text { ton }}$

New woodchips per yr $=2,154$ yd3 (see table below)

New woodchips per dry ton $=2154 \frac{\mathrm{yd}^{3}}{\mathrm{yr}} * \frac{1 \mathrm{yr}}{200 \text { dry tons }}=10.8 \frac{\mathrm{yd}^{3} \text { new woodchips }}{\text { dry ton }}$

Sawdust (organic amendment) $\sim$ see calculations for sawdust per dry ton in compost sizing

Biosolids $\mathrm{C} / \mathrm{N}=15.7 ; \% \mathrm{~N}=1.88$ (Seagren 2019)

Sawdust $\mathrm{C} / \mathrm{N}=400 ; \% \mathrm{~N}=0.1 \%$ (Harris and Phillips 1986)

$\mathrm{C} / \mathrm{N}$ ratio

$=\frac{\left(\frac{\% \mathrm{~N}_{\text {sludge }}}{100}\right) * \frac{\mathrm{C}}{\mathrm{N}} \text { ratio }_{\text {sludge }} * \text { dry wt }+\left(\frac{\% \mathrm{~N}_{\text {sawdust }}}{100}\right) * \frac{\mathrm{C}}{\mathrm{N}} \text { ratio }_{\text {sawdust }} * \text { dry wt }}{\left(\frac{\% \mathrm{~N}_{\text {sludge }}}{100}\right) * \text { dry wt }+\left(\frac{\% \mathrm{~N}_{\text {sawdyst }}}{100}\right) * \text { dry wt }}=30$

$=\frac{\left(\frac{1.88}{100}\right) * 15.7 * 235.5 \frac{\text { dry ton }}{\mathrm{yr}}+\left(\frac{0.1}{100}\right) * 400 * \text { dry wt }}{\left(\frac{1.88}{100}\right) * 235.5 \frac{\text { dry ton }}{\mathrm{yr}}+\left(\frac{0.1}{100}\right) * \text { dry wt }}$

sawdust dry wt $=171.1 \frac{\text { dry ton sawdust }}{\mathrm{yr}}$

1 dry ton sludge: $\frac{171.1}{200}$ dry ton sawdust $=0.855$ dry ton sawdust per dry ton

Sawdust moisture $=35 \%$; Sawdust density $=20 \mathrm{lb} / \mathrm{ft} 3$ (Harris and Phillips 1986)

Volume of sawdyst per dry ton

$$
\begin{aligned}
& =\frac{0.73 \text { dry ton sawdust }}{\text { dry ton biosolids }} * \frac{1}{(1-0.35)} * \frac{2,000 \mathrm{lb}}{1 \mathrm{ton}} * \frac{1 \mathrm{ft}^{3}}{20 \mathrm{lb}} * \frac{1 \mathrm{yd}^{3}}{27 \mathrm{ft}^{3}} \\
& =4.1 \frac{\mathrm{yd}^{3}}{\text { dry ton }}
\end{aligned}
$$

Yearly sawdust volume $=\frac{4.1 \mathrm{yd}^{3}}{\text { dry ton }} * \frac{235 \text { dry ton }}{1 \mathrm{yr}}=974.3 \frac{\mathrm{yd}^{3}}{\mathrm{yr}}$ 
Sawdust volume per final dry tons $=\frac{974.3 \mathrm{yd}^{3}}{\mathrm{yr}} * \frac{1 \mathrm{yr}}{200 \text { dry tons }}=4.87 \frac{\mathrm{yd}^{3}}{\text { dry ton }}$

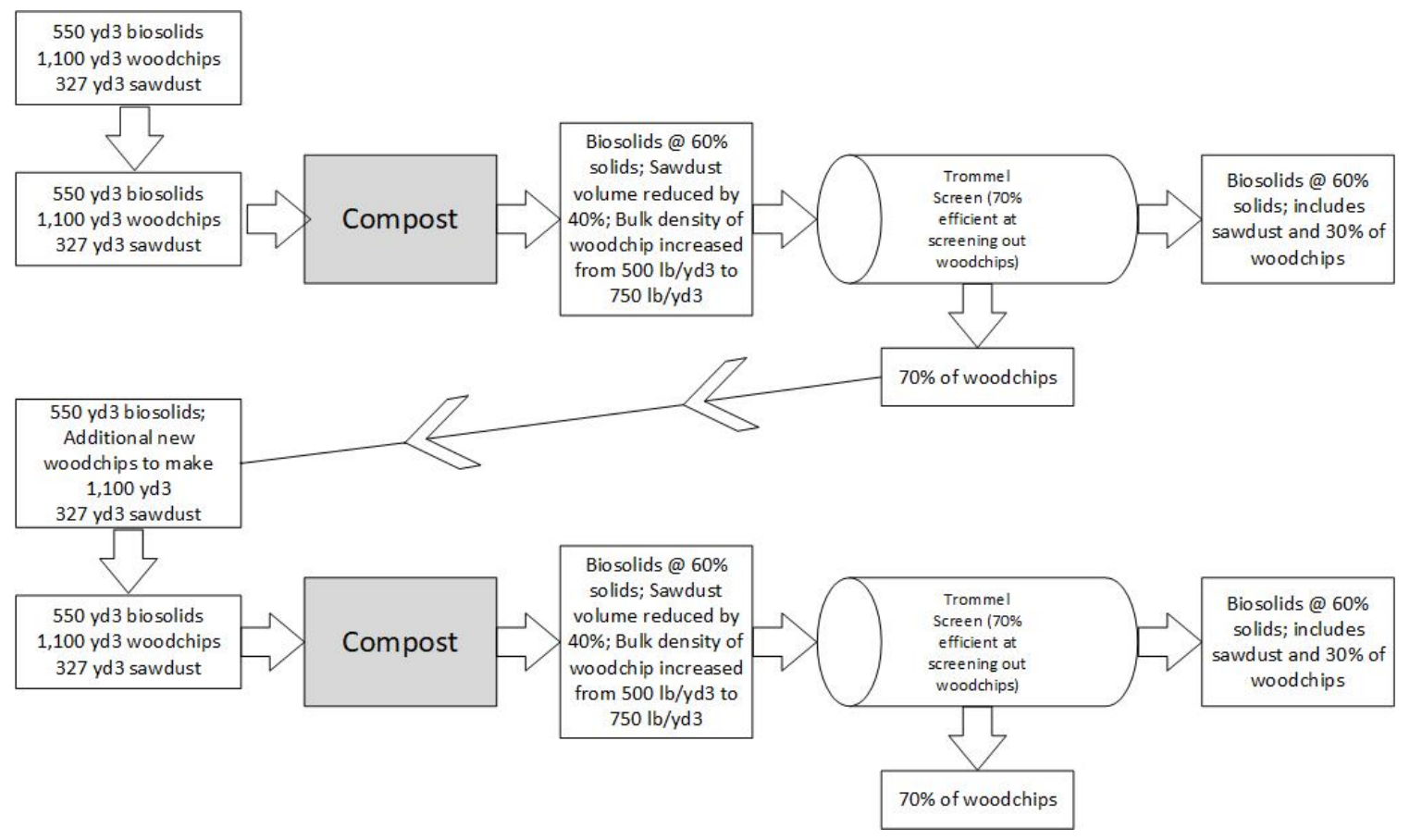

Figure A.3.1. Composting diagram

Table A.3.1 Quantity of biosolids and amendments in composting cycles

\begin{tabular}{|l|l|l|l|l|l|l|}
\hline & \multicolumn{3}{|l|}{$1^{\text {st }}$ cycle } & \multicolumn{2}{l|}{$2^{\text {nd }}$ cycle } & \multicolumn{2}{l|}{$3^{\text {rd }}$ cycle } \\
\hline & Weight & Volume & Weight & Volume & Weight & Volume \\
\hline Biosolids & $\begin{array}{l}357 \mathrm{wet} \\
\text { tons }\end{array}$ & $550 \mathrm{yd} 3$ & $\begin{array}{l}357 \text { wet } \\
\text { tons }\end{array}$ & $550 \mathrm{yd} 3$ & $\begin{array}{l}357 \mathrm{wet} \\
\text { tons }\end{array}$ & $550 \mathrm{yd} 3$ \\
\hline $\begin{array}{l}\text { New } \\
\text { Woodchips }\end{array}$ & $275 \mathrm{tons}$ & $1100 \mathrm{yd} 3$ & 147 tons & $587 \mathrm{yd} 3$ & 117 tons & $467 \mathrm{yd} 3$ \\
\hline $\begin{array}{l}\text { Recycled } \\
\text { woodchips }\end{array}$ & 0 & 0 & 193 tons & $513 \mathrm{yd} 3$ & 237 tons & $663 \mathrm{yd} 3$ \\
\hline Sawdust & 88 tons & $327 \mathrm{yd} 3$ & 88 tons & $327 \mathrm{yd} 3$ & 88 tons & $327 \mathrm{yd} 3$ \\
\hline
\end{tabular}

\section{Compost Sizing}

Time in windrows $=21$ days 
Curing time $=30$ days

Assuming you can compost 3 times a summer

$1 / 3$ volume of yearly biosolids $=44563 \mathrm{ft}^{3} * \frac{1 \mathrm{yr}}{3 \text { cycle }}=14854 \mathrm{ft}^{3}=550 \mathrm{yd}^{3}$

Woodchips per cycle $=1100 \mathrm{yd}^{3}$

Sawdust per cycle $=325 \mathrm{yd}^{3}$

Total volume $=325 \mathrm{yd}^{3}+1100 \mathrm{yd}^{3}+550 \mathrm{yd}^{3}=1975 \mathrm{yd}^{3}$

Windrow characteristics

Height $=4.5 \mathrm{ft}$

Length $=10 \mathrm{ft}$

Clearance between rows $=5 \mathrm{ft}$

Clearance at ends $=7 \mathrm{ft}$

Number of windrows $=12$

Asphalt depth $=0.5 \mathrm{ft}$

Width of composting pad $=5 \mathrm{ft}+(5 \mathrm{ft}+10 \mathrm{ft}) * 12=185 \mathrm{ft}$

Cross sectional area of windrow $=$ Area $=\frac{1}{2} \mathrm{~b} * \mathrm{~h}=0.5 * 10 \mathrm{ft} * 4.5 \mathrm{ft}=22.5 \mathrm{ft}^{2}$

Length $=\frac{\text { Total volume }}{\text { cross sectional area } * \text { \# of windrow }}=\frac{1,975 \mathrm{yd}^{3} * \frac{27 \mathrm{ft}^{3}}{1 \mathrm{yd}^{3}}}{22.5 \mathrm{ft}^{2} * 12}=198 \mathrm{ft}$

Length with clearance $=198 \mathrm{ft}+14 \mathrm{ft}=212 \mathrm{ft}$

Tonnage of asphalt calculated using an online calculator with dimensions and compaction. (CAPA 2019)

Asphalt $=1,438$ tons

Dry ton of biosolids per lifetime $=\mathrm{FU} *$ lifetime $=\frac{200 \text { dry tons }}{\text { year }} * 25 \mathrm{yr}$ $=5,000$ dry tons 
Ashpalt per dry ton $=\frac{1438 \text { ton asphalt }}{5,000 \text { dry tons } / \text { lifetime }}=0.288 \frac{\text { tons asphalt }}{\text { dry ton }}$

Gravel $=0.9 * 0.288 \frac{\text { tons asphalt }}{\text { dry ton }}=0.26 \frac{\text { tons gravel }}{\text { dry ton }}$

Asphalt adhesive $=0.1 * 0.288 \frac{\text { tons asphalt }}{\text { dry ton }}=0.03 \frac{\text { tons asphalt adhesive }}{\text { dry ton }}$

\section{Diesel for frontend loader to move and mix biosolids and amendments}

Given: $0.4 \mathrm{~L}$ diesel per ton (Komilis and Ham 2004). moves biosolids and amendments around pad and to trommel screen

Weight of biosolids $=1,070$ tons

Weight of woodchips $=\frac{2}{3} * \frac{3301 \mathrm{yd}^{3} \text { woodchips }}{\mathrm{yr}} *\left(0.7 * \frac{750 \mathrm{lg}}{\mathrm{yd}^{3}}+0.3 * \frac{500 \mathrm{lb}}{\mathrm{yd}^{3}}\right)+\frac{1}{3} * \frac{3301 \mathrm{yd}^{3}}{\mathrm{yr}}=$ $1018 \frac{\text { tons }}{\mathrm{yr}}$

Weight of sawdust $=\frac{974.3 \mathrm{yd}^{3}}{\mathrm{yr}} * \frac{540 \mathrm{lb}}{\mathrm{yd}^{3}} * \frac{1 \text { ton }}{2000 \mathrm{lb}}=263$ tons

Total weight $=2350$ tons $/ \mathrm{yr}$

$\frac{0.4 \mathrm{~L}}{\text { ton }} * \frac{2350 \text { tons at start of air drying }}{1 \mathrm{yr}} * \frac{1 \mathrm{yr}}{200 \text { dry tons }}=4.7 \mathrm{~L}$ diesel per dry ton

\section{Diesel for turning windrows}

Given: 0.9 L diesel/ton (Komilis and Ham 2004) assumes 3 mixing per week and composted for 8 weeks

$\frac{0.9 \mathrm{~L}}{\text { ton } * 8 \text { weeks }} * 3$ weeks $=0.34 \frac{\mathrm{L}}{\text { ton }}$

$\frac{0.34 \mathrm{~L}}{\text { ton }} * \frac{2350 \text { tons at start of air drying }}{1 y r} * \frac{1 y r}{200 \text { dry tons }}=4 \mathrm{~L}$ diesel per dry ton

\section{Electricity for trommel screen}

Total weight of compost before screening $=1461$ tons $/ \mathrm{yr}$

Electricity to screen $=0.8 \mathrm{kWh} /$ ton $($ Komilis and Ham 2004) 
$\frac{0.8 \mathrm{kWh}}{\text { ton }} * \frac{1461 \text { tons }}{\mathrm{yr}} * \frac{1 \mathrm{yr}}{200 \text { dry ton }}=5.84 \frac{\mathrm{kWh}}{\text { final dry tons }}$

\section{Emissions}

$\mathrm{C} / \mathrm{N}$ ratio $=30$

$\% \mathrm{~N}=1.13 \%$

$\frac{1 \text { dry ton biosolids }}{(1 \text { dry ton biosolids }+0.725 \text { dry ton sawdust })} * 1.88 \%$

$$
\begin{aligned}
& +\left(1-\frac{1 \text { dry ton biosolids }}{(1 \text { dry ton biosolids }+0.725 \text { dry ton sawdust })}\right) * 0.1 \% \\
& =1.13 \%
\end{aligned}
$$

$\% \mathrm{C}=\frac{\% \mathrm{~N}}{100} * \mathrm{C}: \mathrm{N}$ ratio $=\frac{1.13}{100} * 30=33.9 \%$

Dry weight $=\frac{235 d r y \text { tons }}{y r}+\frac{235 d r y \text { tons }}{y r} * \frac{0.73 d r y \text { tons sawdust }}{d r y \text { ton biosolids }}=406 \frac{\text { tons }}{y r}$

Nitrogen Content $=\left(\frac{\% \mathrm{~N}}{100}\right) *$ dry $w t=\left(\frac{1.13}{100}\right) * 406 \frac{\text { dry ton }}{\mathrm{yr}}=4.59 \frac{\text { ton } \mathrm{N}}{\mathrm{yr}}$

Carbon content $=\left(\frac{\% \mathrm{C}}{100}\right) * \mathrm{dry} \mathrm{wt}=\frac{33.9}{100} * 235 \frac{\mathrm{dry} \text { ton }}{\mathrm{yr}}=137.8 \frac{\mathrm{ton} \mathrm{C}}{\mathrm{yr}}$

Carbon reduction $=57 \%$ (Tiquia, Richard et al. 2002)

Nitrogen released $=\left(\frac{33}{100}\right) * 4.59 \frac{\text { ton } \mathrm{N}}{\mathrm{yr}}=1.52 \frac{\text { ton } \mathrm{N}}{\mathrm{yr}}$

Carbon released $=\left(\frac{57}{100}\right) * 137.8 \frac{\text { ton } \mathrm{C}}{\mathrm{yr}}=78.6 \frac{\text { ton } \mathrm{C}}{\mathrm{yr}}$

Methane loss $=1.9 \%$ of initial C (Brown, Kruger et al. 2008). Brown et al (2008) summarizes Hao et al. (2004) study on cattle manure with woodchips in windrow composting and found that $1.9 \%$ of initial $\mathrm{C}$ was released as $\mathrm{CH} 4$.

Methane loss $=\left(\frac{1.9}{100}\right) * 137.8 \frac{\operatorname{ton} \mathrm{C}}{\mathrm{yr}}=2.62 \frac{\operatorname{ton} \mathrm{C} \text { as } \mathrm{CH} 4}{\mathrm{yr}}$

$\mathrm{N} 2 \mathrm{O}$ loss $=0.6 \%$ of N (Brown, Kruger et al. 2008). Brown et al (2008) summarizes Hao et al. (2004) study on cattle manure with woodchips in windrow composting and found that $0.6 \%$ of initial $\mathrm{N}$ was released as $\mathrm{N} 2 \mathrm{O}$

$\mathrm{N} 20$ loss $=\frac{0.6}{100} * 24.59 \frac{\text { ton } \mathrm{N}}{\mathrm{yr}}=0.028 \frac{\text { ton } \mathrm{N} \text { as N2O }}{\mathrm{yr}}$ 
Carbon dioxide released $=$ total $\mathrm{C}$ released $-\mathrm{C}$ released as $\mathrm{CH} 4=78.6 \frac{\text { ton } \mathrm{C}}{\mathrm{yr}}-$ $2.62 \frac{\text { ton } \mathrm{C} \text { as } \mathrm{CH} 4}{\mathrm{yr}}=75.9 \frac{\text { ton } \mathrm{C} \text { as } \mathrm{CO} 2}{\mathrm{yr}}$

$\mathrm{N} 2 \mathrm{O}$ released per dry ton $=\frac{0.028 \text { ton } \mathrm{N} \text { as N2O }}{\mathrm{yr}} * \frac{2000 \mathrm{lb}}{1 \mathrm{ton}} * \frac{1 \mathrm{~kg}}{2.2 \mathrm{lb}} * \frac{1 \mathrm{kmol} \mathrm{N}}{14 \mathrm{~kg}} * \frac{1 \mathrm{kmol} \mathrm{N} 2 \mathrm{O}}{2 \mathrm{kmol} \mathrm{N}} *$ $\frac{44 \mathrm{~kg} \mathrm{~N} 2 \mathrm{O}}{1 \mathrm{kmol} \mathrm{N} 2 \mathrm{O}} * \frac{1 \mathrm{yr}}{200 \text { dry ton }}=0.20 \frac{\mathrm{kg} \mathrm{N} 2 \mathrm{O}}{\text { dry ton }}$

$\mathrm{CH} 4$ released per dry ton $=\frac{12.62 \text { ton } \mathrm{C} \text { as } \mathrm{CO} 2}{\mathrm{yr}} * \frac{2000 \mathrm{lb}}{1 \mathrm{ton}} * \frac{1 \mathrm{~kg}}{2.2 \mathrm{lb}} * \frac{1 \mathrm{kmol} \mathrm{C}}{12 \mathrm{~kg}} * \frac{1 \mathrm{kmol} \mathrm{CH} 4}{1 \mathrm{kmol} \mathrm{C}} *$ $\frac{16 \mathrm{~kg} \mathrm{CH} 4}{1 \mathrm{kmol} \mathrm{CH} 4} * \frac{1 \mathrm{yr}}{200 \text { dry ton }}=15.9 \frac{\mathrm{kg} \mathrm{CH} 4}{\text { dry ton }}$

$\mathrm{CO} 2$ released per dry ton $=\frac{75.9 \text { ton } \mathrm{C} \text { as } \mathrm{CO} 2}{\mathrm{yr}} * \frac{2000 \mathrm{lb}}{1 \mathrm{ton}} * \frac{1 \mathrm{~kg}}{2.2 \mathrm{lb}} * \frac{1 \mathrm{kmol} \mathrm{C}}{12 \mathrm{~kg}} * \frac{1 \mathrm{kmol} \mathrm{CO} 2}{1 \mathrm{kmol} \mathrm{C}} *$ $\frac{44 \mathrm{~kg} \mathrm{CO} 2}{1 \mathrm{kmol} \mathrm{CO} 2} * \frac{1 \mathrm{yr}}{200 \text { dry ton }}=1256.8 \frac{\mathrm{kg} \mathrm{CO} 2}{\text { dry ton }}$

\section{Transportation}

Distance $=50$ miles $=80$ kilometers

Assuming a $40 \%$ volume reduction for sawdust based on the volume reduction of biosolids (Metcalf and Eddy 2014)

Weight of compost $=783$ tons per year

Quantity of compost $=\frac{783 \text { wet tons }}{\mathrm{yr}} * \frac{1 \text { tonne }}{1.10231 \text { ton }}=710 \frac{\text { tonnes }}{\mathrm{yr}}$

Mass Traveled $=\frac{710 \text { tonnes }}{\mathrm{yr}} * 80$ kilometers $=57,143 \mathrm{tkm}$ per year

Size of truck $=20$ cyd

Volume of compost per year $=1,969$ cyd

Truck loads $=\frac{1,969 \text { cyd }}{20 \text { cyd }}=98$

\section{A.3.1 Composting Detailed Results}


Table A.3.2. Composting unit process environmental impacts broken down by inputs and outputs

\begin{tabular}{|l|l|l|l|l|l|}
\hline & $\begin{array}{l}\text { Human } \\
\text { Health }\end{array}$ & $\begin{array}{l}\text { Ecosystem } \\
\text { Quality }\end{array}$ & $\begin{array}{l}\text { Climate } \\
\text { Change }\end{array}$ & Resources & Total \\
\hline Woodchips & 1.6 & 0.2 & 1.2 & 1.3 & 4.3 \\
\hline Sawdust & 4.7 & 0.1 & 4.5 & 4.9 & 14.1 \\
\hline Diesel Fuel & 0.1 & 0 & 0.1 & 0.5 & 0.8 \\
\hline $\begin{array}{l}\text { Biogenic } \\
\text { Carbon } \\
\text { Dioxide }\end{array}$ & 0 & 0 & 14.8 & 0 & 14.8 \\
\hline $\begin{array}{l}\text { Biogenic } \\
\text { Methane }\end{array}$ & 0 & 0 & 5.2 & 0 & 5.2 \\
\hline $\begin{array}{l}\text { Biogenic } \\
\text { Nitrous } \\
\text { Oxide }\end{array}$ & 0 & 0 & 0.6 & 0 & 0.6 \\
\hline $\begin{array}{l}\text { Fossil } \\
\text { Carbon } \\
\text { Dioxide }\end{array}$ & 0 & 0 & 0.5 & 0 & 0.5 \\
\hline Electricity & 0.1 & 0 & 0.1 & 0 & 0.3 \\
\hline Asphalt Mix & 2.9 & 0.1 & 0.4 & 0.1 & 2.9 \\
\hline Total & $\mathbf{7 . 0}$ & $\mathbf{0 . 5}$ & $\mathbf{2 7 . 4}$ & $\mathbf{8 . 7}$ & $\mathbf{4 3 . 5}$ \\
\hline
\end{tabular}

\section{A.4 Direct Heat Drying Calculations}

Mechanical Dewatering

\section{Electricity}

EPA belt filter press electricity usage algorithm

$\mathrm{E}=\left[-5.42\left(\mathrm{TBFW}^{3}\right)+234.6\left(\mathrm{TBFW}^{2}\right)+16,020(\mathrm{TBFW})+13,997\right]($ USEPA 1985)

Where:

- $\quad \mathrm{E}=$ Annual electrical energy required $(\mathrm{kWhr} / \mathrm{yr}) * *$

- $\quad$ TBFW $=$ Total belt filter width (m)

**assumes $8 \mathrm{hr}$ work days for 365 operational days/yr

$E=[-5.42(1 m)+234.6(1 m)+16,020(1 m)+13,997=30,246 k W h / y r$

Daily electricity use $=30,246 \frac{\mathrm{kWh}}{\mathrm{yr}} * \frac{1 \mathrm{yr}}{365 \text { days }}=82.9 \mathrm{kWh} /$ day 


$$
\begin{aligned}
\text { Electricity Use per } \mathrm{FU} & =\frac{82.9 \mathrm{kWh}}{\text { day }} * \frac{2 \text { operational day }}{\text { week }} * \frac{52 \text { week }}{1 \mathrm{yr}} * \frac{1 \mathrm{yr}}{200 \text { dry ton }} \\
= & 43.1 \frac{\mathrm{kWh}}{\text { dry ton }}
\end{aligned}
$$

\section{Sizing}

Given:

- $\quad$ Loading rate $=700$ dry lbs per hour per meter of width (Metcalf and Eddy 2014)

- Work week $=2$ day per week

- $\quad$ Work day $=8 \mathrm{hrs} /$ day

Daily rate $($ dry $)=$ Weight of dry solids $* \frac{2,000 \mathrm{lb}}{1 \text { ton }} * \frac{1 \mathrm{yr}}{365 \text { days }}$

$$
=\frac{200 \text { dry ton }}{\text { year }} * \frac{2,000 \mathrm{lb}}{1 \text { ton }} * \frac{1 \mathrm{yr}}{365 \text { days }}=1,095.9 \frac{\mathrm{lb}}{\text { day }}
$$

Operational daily rate $($ dry $)=$ daily rate $* \frac{7 \text { days }}{1 \text { week }} * \frac{1 \text { week }}{2 \text { operational days }}$

$$
=\frac{1,095.9 \mathrm{lb}}{\text { day }} * \frac{7 \text { days }}{\text { week }} * \frac{1 \text { week }}{2 \text { operational day }}=3,835.7 \frac{\mathrm{lb}}{\text { operational day }}
$$

Hourly rate $=\frac{\text { operational daily rate }(\mathrm{dry})}{\text { hours per work day }}=\frac{\frac{3,835.7 \mathrm{lb}}{\text { operational day }}}{\frac{8 \text { hours }}{\text { operational day }}}=479 \frac{\mathrm{lb}}{\mathrm{hr}}$

Belt Width $=\frac{\text { hourly rate }}{\text { loading rate }}=\frac{479 \frac{\mathrm{lb}}{\mathrm{hr}}}{700 \frac{\mathrm{lb}}{\mathrm{hr} \mathrm{m}}}=0.7 \mathrm{~m}$

Round up to the next commercially available size $=1.0 \mathrm{~m}$

\section{Wash water}

Wash water needed $=50$ gallons per minute per meter of belt width (Metcalf and Eddy 2014)

$$
\begin{gathered}
\text { Wash water needed }=\frac{50 \text { gal }}{\text { minute }} * \frac{60 \text { minutes }}{1 \mathrm{hr}} * \frac{8 \text { hours }}{1 \text { work day }} * \frac{104 \text { work days }}{1 \mathrm{yr}} \\
=2,496,000 \frac{\text { gallons }}{\text { year }}
\end{gathered}
$$


Wash water needed $=\frac{\frac{2,496,000 \text { gallons }}{\text { year }}}{\frac{200 \text { dry tons }}{\mathrm{yr}}}=12,480 \frac{\text { gallons }}{\text { final dry tons }}$

\section{Polymer}

Polymer $=6 \mathrm{~g} / \mathrm{dry}$ kg solids (Metcalf and Eddy 2014)

$$
\begin{gathered}
\text { polymer }=\frac{6 \mathrm{~g} \text { polymer }}{\mathrm{kg} \text { dry solids }} * \frac{1 \mathrm{~kg}}{2.2 \mathrm{lb}} * \frac{2,000 \mathrm{lb}}{1 \mathrm{ton}} \\
=5,454.5 \mathrm{~g} \text { polymer per ton of dry solids }
\end{gathered}
$$

$$
\begin{aligned}
\text { polymer }= & \frac{5,454.5 \mathrm{~g} \text { polymer }}{1 \text { ton dry solids }} * \frac{1 \mathrm{~kg}}{1000 \mathrm{~g}} * \frac{2.2 \mathrm{lb}}{1 \mathrm{~kg}} * \frac{200 \text { ton } \text { dry solids }}{1 \mathrm{yr}} \\
=2400 \text { lb polymer per year } &
\end{aligned}
$$

$\frac{2400 \mathrm{lb} \text { polymer }}{y r} * \frac{1 \mathrm{yr}}{200 \text { dry tons }}=12 \mathrm{lb}$ polymer per dry ton

\section{Water for polymer dilution}

$0.5 \%$ dilution of polymer needed

$$
\begin{aligned}
& \left(\frac{5454 \text { g polymer }}{\text { dryton }}\right)
\end{aligned}
$$

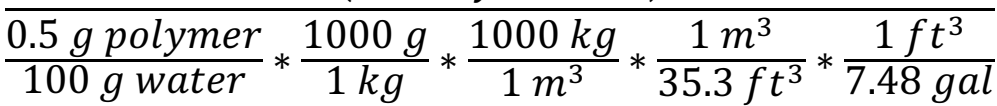

$$
\begin{aligned}
& =288 \text { gal water per dry ton solids }
\end{aligned}
$$

\section{Filtrate}

Filtrate (water removed from biosolids) calculated using a mass balance (wet tons before $B F P-$ wet tons after $B F P)=$

$$
\left(\frac{4,444 \text { tons }}{y r}-\frac{909 \text { tons }}{y r}\right) *\left(\frac{2,000 l b}{1 \text { ton }} * \frac{1 f t^{3}}{62.4 l b} * \frac{7.48 \mathrm{gal}}{1 \mathrm{ft}^{3}}\right)=4,238 \frac{\mathrm{gal}}{\text { dry ton }}
$$

Direct Heat Dryer (rotary)

1. Natural Gas

Energy needed $=1,600$ BTU/lb H2O evaporated (USEPA 2006) 
$\mathrm{H} 2 \mathrm{O}$ evaporated $=$ wet tons before heat drying - wet tons after heat drying

$$
=\left(\frac{909 \text { tons }}{\mathrm{yr}}-\frac{211 \text { tons }}{\mathrm{yr}}\right) *\left(\frac{2,000 \mathrm{lb}}{1 \mathrm{ton}}\right)=1,397,129 \frac{\mathrm{lb} \mathrm{H} 20}{\mathrm{yr}}
$$

Energy Required $=\frac{1,600 \mathrm{BTU}}{\mathrm{lb} \mathrm{H} 2 \mathrm{O} \text { evaporated }} * \frac{1,397,129 \mathrm{lb} \mathrm{H} 20}{\mathrm{yr}} * \frac{0.001055 \mathrm{MJ}}{1 \mathrm{BTU}}$

$$
=2,358,354 \frac{\mathrm{MJ}}{\mathrm{yr}}
$$

Natural gas volume $=\frac{2,358,354 \mathrm{MJ}}{\mathrm{yr}} * \frac{1 \mathrm{~m}^{3}}{38 \mathrm{MJ}} * \frac{1 \mathrm{yr}}{200 \text { dry ton }}=310 \frac{\mathrm{m}^{3}}{\text { dry ton }}$

Transportation

Distance $=50$ miles $=80$ kilometers

Quantity of biosolids $=\frac{211 \text { wet tons }}{y r} * \frac{1 \text { tonne }}{1.10231 \text { ton }}=191 \frac{\text { tonnes }}{y r}$

Mass Traveled $=\frac{191 \text { tonnes }}{\mathrm{yr}} * 80$ kilometers $=15,367 \mathrm{tkm}$ per year

Size of truck $=20 \mathrm{cyd}$

Volume using dewatered density $\left(\frac{48 \mathrm{lb}}{\mathrm{ft}^{3}}\right)=\frac{200 \text { wet tons }}{\text { day }} * \frac{2000 \mathrm{lb}}{1 \mathrm{ton}} * \frac{1 \mathrm{ft}^{3}}{48 \mathrm{lb}}$

$$
=8,333 \mathrm{ft}^{3}
$$

Volume at $95 \%$ solids $=\frac{\% \text { solids at known volume }}{\% \text { solids }}$ Volume $_{\text {know }}=\frac{0.22}{0.95} * 8,333 \mathrm{ft}^{3}$

$$
=1,930 \mathrm{ft}^{3}
$$

Volume per operational day $=\frac{1,930 \mathrm{ft}^{3}}{\text { day }} * \frac{1 \mathrm{cyd}}{27 \mathrm{ft}^{3}}=71.5 \frac{\mathrm{cyd}}{\mathrm{day}}$

Weighted trucks $=\frac{71.5 \text { cyd }}{20 \text { cyd }} * 5=18$ trips

\section{A.5 TPAD Calculations}

Thermophilic digestion

\section{Heating energy}


Heat energy needed $=\frac{2.09 \mathrm{GJ}}{\text { day }}($ Puchajda and Oleszkiewicz 2008)

Energy content of natural gas $=\frac{38 \mathrm{MJ}}{\mathrm{m}^{3}}$

Natural gas needed $=\frac{2.09 \mathrm{GJ}}{\text { day }} * \frac{10^{3} \mathrm{MJ}}{1 \mathrm{GJ}} * \frac{1 \mathrm{~m}^{3}}{38 \mathrm{MJ}}=55 \frac{\mathrm{m}^{3}}{\text { day }}$

Natural gas per year $=55 \frac{\mathrm{m}^{3}}{\text { day }} * \frac{365 \text { day }}{1 \mathrm{yr}}=20,075 \frac{\mathrm{m}^{3}}{\mathrm{yr}}$

Natural Gas per dry ton $=20,075 \frac{\mathrm{m}^{3}}{\mathrm{yr}} * \frac{1 \mathrm{yr}}{200 \text { dry ton }}=100 \frac{\mathrm{m}^{3}}{\text { dry ton }}$

\section{Electricity for mixing and pumping}

Electricity $=\frac{75 \mathrm{kWh}}{\text { ton dry material }}($ Suh and Rousseaux 2002)

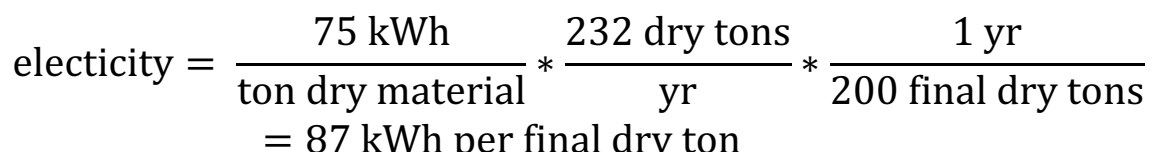

\section{Size of Digestor}

Volume of sludge $=163,471 \mathrm{ft}^{3} * \frac{1 \mathrm{yr}}{365 \text { days }}=448 \frac{\mathrm{ft}^{3}}{\text { day }}$

$\mathrm{SRT}=15$ days

Digestor size $=$ flow $*$ SRT $=\frac{448 \mathrm{ft}^{3}}{\text { day }} * 15$ days $=6718 \mathrm{ft}^{3}$

Digestor size with 1.25 safety factor $=6718 \mathrm{ft}^{3} * 1.25=8397 \mathrm{ft}^{3}$

\section{Biogas production}

Methane $=0.35 \mathrm{~L} \mathrm{CH4}$ per g of VS destroyed (Riau, Rubia et al. 2010)

Assuming biogas is $60 \% \mathrm{CH} 4$ and $40 \% \mathrm{CO} 2$

$\mathrm{CO} 2$ released $=\frac{0.60}{0.40}=\frac{0.35 \frac{\mathrm{L} \mathrm{CH} 4}{\mathrm{~g} \text { of VS destroyed }}}{\mathrm{X}} \gg \mathrm{X}=0.233 \frac{\mathrm{L} \mathrm{CO} 2}{\mathrm{~L} \mathrm{of} \mathrm{CH} 4}$ (USEPA 2006)

VS destroyed in Thermophilic digestion $=32 \%$ (Riau, Rubia et al. 2010)

VS destroyed $=232$ dry tons -200 dry tons $=32$ tons of VS 
32 tons $* \frac{2000 \mathrm{lb}}{1 \mathrm{ton}} * \frac{1 \mathrm{~kg}}{2.2 \mathrm{lb}} * \frac{1000 \mathrm{~g}}{1 \mathrm{~kg}}=29,107,783 \mathrm{~g}$ VS destroyed

Methane produced $=\frac{0.35 \mathrm{~L} \mathrm{CH} 4}{\mathrm{~g} \text { of VS destroyed }} * \frac{29,107,783 \mathrm{~g} \text { of VS destryoed }}{\mathrm{yr}}$ $=10,187,724 \mathrm{l} \mathrm{CH} 4$

Methane produced per dry ton $=\frac{10,187,724 \mathrm{~L} \mathrm{Ch} 4}{200 \text { final dry tons }}$ $=50,939 \mathrm{~L} \mathrm{CH} 4$ per final dry ton

Carbon dioxide $=\frac{0.233 \mathrm{~L} \mathrm{CO} 2}{\mathrm{~L} \mathrm{CH} 4} * \frac{50,939 \mathrm{~L} \mathrm{CH} 4}{\text { final dry ton }}=11,869 \mathrm{~L} \mathrm{CO} 2$ per final dry ton

Belt Filter Press

\section{Electricity}

EPA belt filter press electricity usage algorithm

$\mathrm{E}=\left[-5.42\left(\mathrm{TBFW}^{3}\right)+234.6\left(\mathrm{TBFW}^{2}\right)+16,020(\mathrm{TBFW})+13,997\right](\mathrm{USEPA} 1985)$

Where:

- $\quad \mathrm{E}=$ Annual electrical energy required $(\mathrm{kWhr} / \mathrm{yr}) * *$

- $\quad$ TBFW $=$ Total belt filter width (m)

**assumes $8 \mathrm{hr}$ work days for 365 operational days/yr

$E=[-5.42(1 m)+234.6(1 m)+16,020(1 m)+13,997=30,246 \mathrm{kWh} / \mathrm{yr}$

Daily electricity use $=30,246 \frac{\mathrm{kWh}}{\mathrm{yr}} * \frac{1 \mathrm{yr}}{365 \text { days }}=82.9 \mathrm{kWh} /$ day

$$
\begin{aligned}
\text { Electricity Use per } \mathrm{FU} & =\frac{82.9 \mathrm{kWh}}{\text { day }} * \frac{2 \text { operational day }}{\text { week }} * \frac{52 \text { week }}{1 \mathrm{yr}} * \frac{1 \mathrm{yr}}{200 \text { dry ton }} \\
= & 43.1 \frac{\mathrm{kWh}}{\text { dry ton }}
\end{aligned}
$$

\section{Belt Filter Press Sizing}

Given

- Loading rate $=700$ dry lbs per hour per meter of width (Metcalf and Eddy 2014)

- Work week $=2$ day per week 
- $\quad$ Work day $=8 \mathrm{hrs} /$ day

Daily rate $($ dry $)=$ Weight of dry solids $* \frac{2,000 \mathrm{lb}}{1 \text { ton }} * \frac{1 \mathrm{yr}}{365 \text { days }}$

$$
=\frac{200 \text { dry ton }}{\text { year }} * \frac{2,000 \mathrm{lb}}{1 \text { ton }} * \frac{1 \mathrm{yr}}{365 \text { days }}=1,096 \frac{\mathrm{lb}}{\text { day }}
$$

Operational daily rate $($ dry $)=$ daily rate $* \frac{7 \text { days }}{1 \text { week }} * \frac{1 \text { week }}{2 \text { operational days }}$

$$
=\frac{1,096 \mathrm{lb}}{\text { day }} * \frac{7 \text { days }}{\text { week }} * \frac{1 \text { week }}{2 \text { operational day }}=3836 \frac{\mathrm{lb}}{\text { operational day }}
$$

Hourly rate $=\frac{\text { operational daily rate }(\text { dry })}{\text { hours per work day }}=\frac{\frac{3836 \mathrm{lb}}{\text { operational day }}}{\frac{8 \text { hours }}{\text { operational day }}}=479 \frac{\mathrm{lb}}{\mathrm{hr}}$

Belt Width $=\frac{\text { hourly rate }}{\text { loading rate }}=\frac{479 \frac{\mathrm{lb}}{\mathrm{hr}}}{700 \frac{\mathrm{lb}}{\mathrm{hr} \mathrm{m}}}=0.7 \mathrm{~m}$

Round up to the next commercially available size $=1.0 \mathrm{~m}$

\section{Wash Water}

Wash water needed $=50$ gallons per minute per meter of belt width (Metcalf and Eddy 2014)

Wash water needed $=\frac{50 \text { gal }}{\text { minute }} * \frac{60 \text { minutes }}{1 \mathrm{hr}} * \frac{8 \text { hours }}{1 \text { work day }} * \frac{104 \text { work days }}{1 \mathrm{yr}}$

$$
=2,496,000 \frac{\text { gallons }}{\text { year }}
$$

Wash water needed $=\frac{\frac{2,496,000 \text { gallons }}{\frac{\text { year }}{200 \text { dry tons }}}}{\text { yr }}=12,480 \frac{\text { gallons }}{\text { final dry tons }}$

\section{Polymer}

Polymer $=6$ g/dry kg solids (Metcalf and Eddy 2014) 


$$
\begin{aligned}
& \text { polymer }=\frac{6 \text { g polymer }}{\mathrm{kg} \text { dry solids }} * \frac{1 \mathrm{~kg}}{2.2 \mathrm{lb}} * \frac{2,000 \mathrm{lb}}{1 \mathrm{ton}} \\
& =5,454.5 \mathrm{~g} \text { polymer per ton of dry solids } \\
& \text { polymer }=\frac{5,454.5 \mathrm{~g} \text { polymer }}{1 \text { ton dry solids }} * \frac{1 \mathrm{~kg}}{1000 \mathrm{~g}} * \frac{2.2 \mathrm{lb}}{1 \mathrm{~kg}} * \frac{200 \text { ton dry solids }}{1 \mathrm{yr}} \\
& =2400 \mathrm{lb} \text { polymer per year }
\end{aligned}
$$$$
\frac{2400 \mathrm{lb} \text { polymer }}{\mathrm{yr}} * \frac{1 \mathrm{yr}}{200 \mathrm{dry} \text { tons }}=12 \mathrm{lb} \text { polymer per dry ton }
$$

\section{Water for polymer dilution}

$0.5 \%$ dilution of polymer needed

$$
\begin{gathered}
\frac{\left(\frac{5454 \text { g polymer }}{\text { dry ton }}\right)}{\frac{0.5 \text { g polymer }}{100 \text { g water }} * \frac{1000 \mathrm{~g}}{1 \mathrm{~kg}} * \frac{1000 \mathrm{~kg}}{1 \mathrm{~m}^{3}} * \frac{1 \mathrm{~m}^{3}}{35.3 \mathrm{ft}^{3}} * \frac{1 \mathrm{ft}^{3}}{7.48 \mathrm{gal}}} * \frac{200 \text { dry tons }}{\mathrm{yr}} \\
* \frac{\mathrm{yr}}{200 \text { final dry tons }}=288 \text { gal water per dry ton solids }
\end{gathered}
$$

\section{Filtrate}

Filtrate (water removed from biosolids) calculated using a mass balance (wet tons before BFP - wet tons after BFP) =

$$
\begin{aligned}
\left(\frac{3333 \text { tons }}{\mathrm{yr}}-\right. & \left.\frac{909 \text { tons }}{\mathrm{yr}}\right) *\left(\frac{2,000 \mathrm{lb}}{1 \text { ton }} * \frac{1 \mathrm{ft}^{3}}{62.4 \mathrm{lb}} * \frac{7.48 \mathrm{gal}}{1 \mathrm{ft}^{3}}\right) * \frac{1 \mathrm{yr}}{200 \text { final dry tons }} \\
& =2906 \frac{\text { gal }}{\text { dry ton }}
\end{aligned}
$$

\section{Transportation}

Distance $=50$ miles $=80$ kilometers

Quantity of biosolids $=\frac{909 \text { wet tons }}{\mathrm{yr}} * \frac{1 \text { tonne }}{1.10231 \text { ton }}=825 \frac{\text { tonnes }}{\mathrm{yr}}$

Mass Traveled $=\frac{825 \text { tonnes }}{\mathrm{yr}} * 80$ kilometers $=66,359 \mathrm{tkm}$ per year

Size of truck $=20$ cyd

Volume of biosolids $=37879 \mathrm{ft}^{3}=1403 \mathrm{yd}^{3}$ 
Loads $=\frac{1403 \frac{\mathrm{cyd}}{\mathrm{yr}}}{20 \mathrm{cyd}}=70$ trips

\section{A.6 Cost Analysis Calculations}

Please see the EPA Sludge Management Cost Estimating Handbook for step-by-step calculations of the O\&M cost for the belt filter press, labor requirements of Composting, and trucking and the grading, clearing, and paving costs for Composting, Air Drying, and Lagoon Storage.

\section{A.6.1 Air Drying cost calculations}

\section{Belt filter press}

Capital Cost $=\$ 167,696($ USEPA 2000)

\section{Air Drying}

O\&M: Labor

Given:

- Two 10 week cycles

- 1 turn per week

- $\quad$ Speed of windrow turner $=20 \mathrm{ft} / \mathrm{min}$

- $\quad$ Length of windrow $=259 \mathrm{ft}$

- $\quad$ Number of windrows $=12$

Assumptions

- $\quad$ Time spend placing biosolids in windrows $=2$ days

- Hours per work day $=8 \mathrm{hr}$

- 40 hours of maintenance per year

Total time spent placing $=\frac{2 \text { day }}{\text { cycle }} * \frac{8 \text { hours }}{1 \text { work day }}=16 \frac{\text { hours }}{\text { cycle }}$

Assuming the same amount of time is spent removing the biosolids.

Number of turnings $=\frac{1 \text { turn }}{\text { week }} * \frac{10 \text { weeks }}{1 \text { cycle }}=10 \frac{\text { turns }}{\text { cycle }}$

Total length of windrows $=\frac{259 \mathrm{ft}}{\text { windrow }} * 12$ windrows $=3,108 \mathrm{ft}$

Time for mixing $=\frac{3108 \mathrm{ft}}{20 \mathrm{ft} / \mathrm{min}} * \frac{1 \mathrm{hr}}{60 \mathrm{~min}} * \frac{10 \mathrm{turns}}{\text { cycle }}=25.9 \frac{\text { hours }}{\mathrm{cycle}}$ 
$25.9 \frac{\text { hours }}{\text { cycle }} * 2$ cycles $=57.9 \frac{\text { hours }}{y r}$

Total time $=16 \frac{\text { hours }}{\text { cycle }} * 2$ cycles $* 2+57.9 \frac{\text { hours }}{y r}=115.8$ hours

Labor cost $=\$ 22.50($ BLS 2017)

Labor $=\left(115.8 \frac{\text { hours }}{y r}+40 \frac{\text { hours }}{y r}\right) * \$ 22.50=\$ 3,450.97$

O\&M: Diesel Fuel

Given:

- Diesel for dump truck (BFP -> air drying pad $)=0.47 \mathrm{~L} /$ dry ton

- Diesel for front-end loader $=1.87 \mathrm{~L} /$ dry ton

- Diesel for turning $=1.31 \mathrm{~L} /$ dry ton

Yearly Diesel $=\left(0.47 \frac{L}{\text { dry ton }}+1.87 \frac{L}{\text { dry ton }}+1.31 \frac{L}{\text { dry ton }}\right) * \frac{200 \text { dry ton }}{y r}$

$$
=730 \frac{L}{\text { year }}
$$

$730 \frac{\mathrm{L}}{\text { year }} * \frac{1 \mathrm{gal}}{3.785 \mathrm{~L}}=193 \frac{\mathrm{gal}}{\text { year }}$

Cost of diesel $=\$ 2.98$ per gallon (EIA 2019)

Cost of diesel $=193 \frac{\text { gal }}{\text { year }} * \frac{\$ 2.98}{\text { gal }}=\$ 575$

Capital: Windrow Turner

It was not assumed the WRRFs already own a windrow turner.

Cost of windrow turner in $1996=\$ 15,000$ (UW-Madison 1996)

Cost of windrow turner in $2019=\$ 24,000$ (based on inflation)

\section{A.6.2 Lagoon Storage cost calculations}

\section{Belt filter press}

Capital Cost $=\$ 167,696($ USEPA 2000) 


\section{Lagoon Storage + Air Drying}

Given:

- 10 weeks of air drying

- 1 turn per week

- $\quad$ Speed of windrow turner $=20 \mathrm{ft} / \mathrm{min}$

- Length of windrow $=275 \mathrm{ft}$

- $\quad$ Number of windrows $=17$

Assumption

- Hauling biosolids from BFP to lagoon $=52$ hours $/ y r$

- Placing biosolids into lagoon $=52$ hours/yr

- Removing biosolids from lagoon $=61$ hours $/ y r$

- Hours removing from air drying pad $=16$ hours/yr

Number of turnings $=\frac{1 \text { turn }}{\text { week }} * \frac{10 \text { weeks }}{1 y r}=10 \frac{\text { turns }}{y r}$

Total length of windrows $=\frac{275 \mathrm{ft}}{\text { windrow }} * 17$ windrows $=4,675 \mathrm{ft}$

Time for mixing $=\frac{4675 \mathrm{ft}}{20 \mathrm{ft} / \mathrm{min}} * \frac{1 \mathrm{hr}}{60 \mathrm{~min}} * \frac{10 \text { turns }}{\text { cycle }}=39 \frac{\text { hours }}{\text { cycle }}$

Total time $=$ turning time + placing times

$$
=39 \frac{\text { hours }}{y r}+52 \frac{\text { hr }}{y r}+52 \frac{\text { hours }}{y r}+61 \frac{\text { hours }}{y r}+16 \frac{\text { hours }}{y r}=220 \text { hours }
$$

Labor cost $=\$ 22.50($ BLS 2017)

Labor $=\left(220 \frac{\text { hours }}{y r}+40 \frac{\text { hours }}{y r}\right) * \$ 22.50=\$ 5,758.08$

\section{O\&M: Diesel Fuel}

Given:

- $\quad$ Diesel for dump truck (BFP -> lagoons $)=0.47 \mathrm{~L} /$ dry ton

- Diesel for spreading biosolids in lagoons $=0.73 \mathrm{~L} /$ dry ton

- $\quad$ Diesel for front-end loader $=1.2 \mathrm{~L} /$ dry ton

- Diesel for turning $=0.78 \mathrm{~L} /$ dry ton 
Yearly Diesel

$$
\begin{aligned}
& =\left(0.47 \frac{L}{\text { dryton }}+0.73 \frac{L}{\text { dryton }}+1.2 \frac{L}{\text { dry ton }}+0.78 \frac{L}{\text { dry ton }}\right) \\
& * \frac{200 \text { dryton }}{y r}=636 \frac{L}{\text { year }}
\end{aligned}
$$

$636 \frac{\mathrm{L}}{\text { year }} * \frac{1 \mathrm{gal}}{3.785 \mathrm{~L}}=168 \frac{\mathrm{gal}}{\text { year }}$

Cost of diesel $=\$ 2.98$ per gallon (EIA 2019)

Cost of diesel $=168 \frac{\mathrm{gal}}{\text { year }} * \frac{\$ 2.98}{\text { gal }}=\$ 501$

Capital: Windrow Turner

It was not assumed the WRRFs already own a windrow turner.

Cost of windrow turner in $1996=\$ 15,000$ (UW-Madison 1996)

Cost of windrow turner in $2019=\$ 24,000$ (based on inflation)

Capital: Clay and Liner

Quantity of clay $=1,865.16$ tons

Cost of clay $=\$ 13.00 /$ ton (Statista 2019)

cost of clay $=\frac{\$ 13}{\text { ton }} * 1865$ tons $=\$ 24,247.08$

Quantity of liner $=77,067 \mathrm{ft} 2$

Cost of liner $=\$ 0.82 / \mathrm{ft} 2($ Agru 2019)

Cost of liner $=77,067 f t^{2} * \frac{\$ 0.82}{f t^{2}}=\$ 63,194.94$ 
Table A.6.1 Capital cost of lagoons and air drying

\begin{tabular}{|l|r|}
\hline Parameter & Cost \\
\hline Construction & $\$ 3,360$ \\
\hline Site Clearing & \\
\hline Liner Installation $^{\mathrm{b}}$ & $\$ 181,878.12$ \\
\hline Site Grading $^{\mathrm{a}}$ & $\$ 26,884.29$ \\
\hline Compaction $^{\mathrm{b}}$ & $\$ 106.60$ \\
\hline Materials & $\$ 24,247.08$ \\
\hline Clay $^{\mathrm{c}}$ & $\$ 63,194.94$ \\
\hline Liner $^{\mathrm{d}}$ & $\$ 124,153.19$ \\
\hline Asphalt $^{\mathrm{a}}$ & $\$ 24,000$ \\
\hline Equipment $^{\mathrm{a}}$ & \\
\hline Windrow Turner & \\
\hline TOTAL & $\mathbf{4 4 7 , 8 2 4 . 2 2}$ \\
\hline
\end{tabular}

a (USEPA 1985)

b(USEPA 2002)

c(Statista 2019)

d(Agru 2019)

e(UW-Madison 1996)

\section{A.6.3 Composting Cost Calculations}

\section{Belt filter press}

Capital Cost $=\$ 167,696($ USEPA 2000)

\section{Composting}

\section{O\&M: Diesel Fuel}

- Diesel for dump truck (BFP -> compost pad $)=0.47 \mathrm{~L} / \mathrm{dry}$ ton

- Diesel for turning windrows $=3.9 \mathrm{~L} /$ dry ton

- Diesel for mixing amendments and biosolids together $=4.6 \mathrm{~L} / \mathrm{dry}$ ton

$$
\begin{aligned}
\text { Yearly diesel } & =\left(0.47 \frac{L}{\text { dryton }}+3.9 \frac{L}{\text { dryton }}+4.6 \frac{L}{\text { dry ton }}\right) * \frac{200 \text { dry ton }}{y r} \\
& * \frac{\text { gal }}{3.785 \mathrm{~L}}=473 \frac{\text { gal }}{\text { year }}
\end{aligned}
$$

Cost of diesel $=\$ 2.98$ per gallon $($ EIA 2019)

Cost of diesel $=473 \frac{\text { gal }}{\text { year }} * \frac{\$ 2.98}{\text { gal }}=\$ 1,410$

O\&M: Electricity 
Electricity for trommel screen $=1,169 \mathrm{kWh} / \mathrm{yr}$

Cost of electricity $=0.10 \$ / \mathrm{kWh}($ EIA 2019)

Cost of electricity $=0.10 \frac{\$}{\mathrm{kWh}} * \frac{1169 \mathrm{kWh}}{\mathrm{yr}}=\$ 121$

O\&M: Amendments

Sawdust $=146$ dry tons $/ \mathrm{yr}$

Woodchips $=2154$ cyd

Cost of sawdust $=\$ 50 /$ dry ton $(\operatorname{AgMRC} 2018)$

Cost of woodchips $=\$ 25 /$ cyd $($ Smith 2019)

Cost of sawdust $=\frac{\$ 50}{\text { dryton }} * \frac{146 d r y \text { ton }}{y r}=\$ 7,300$

Cost of woodchips $=\frac{\$ 25}{c y d} * \frac{2154 c y d}{y r}=\$ 53,850$

Capital: Windrow Turner

It was not assumed the WRRFs already own a windrow turner.

Cost of windrow turner in $1996=\$ 15,000$ (UW-Madison 1996)

Cost of windrow turner in $2019=\$ 24,000$ (based on inflation)

\section{A.6.4 Direct Heat Drying cost analysis}

\section{Belt filter press}

Capital Cost $=\$ 167,696($ USEPA 2000)

\section{Rotary Dryer}

Capital cost: Rotary dryer

Rotary dryer $=\$ 11.5$ million (USEPA 2006)

O\&M: natural gas

Cost of natural gas $=\$ 5.46$ per $1000 \mathrm{ft} 3($ EIA 2019)

$310 \mathrm{~m} 3 /$ day natural gas 
$\frac{310 \mathrm{~m}^{3}}{d r y \text { ton }} * \frac{200 d r y \text { tons }}{y r} * \frac{35.315 f t^{3}}{1 m^{3}}=2,189,530 \frac{f t^{3}}{y r}$

\section{A.6.5 TPAD cost analysis}

O\&M: everything together.

Operation $=\$ 21.9 /$ dry ton

Maintenance $=\$ 9.33 /$ dry ton

Dry tons before Thermophilic digestion $=231$ dry tons

cost of $O \& M=\frac{\$ 9.33}{\text { dry ton }} * \frac{231 \text { dry tons }}{y r}+\frac{\$ 21.90}{\text { dry ton }} * \frac{231 \text { dry tons }}{y r}=\$ 7,245 /$ year

Capital Cost: TPAD system

Capital cost $=\$ 32,600,000 / 2=\$ 16,300,000($ USEPA 2006)

Cost is divided by two because it was for a four-digester system, not two.

\section{Belt filter press}

Capital Cost $=\$ 167,696($ USEPA 2000) 